WSRC-TR-2000-00506

SRT-RPP-2001-00006

BNF-003-98-0317

KEYWORDS:

Hanford River Protection Project

Filtration

Separation Processes

Transuranic

\title{
Strontium-Transuranic Precipitation and Crossflow Filtration of 241-AN-102 Large C
}

Charles A. Nash, 773-42A

Hiroshi H. Saito, 773-42A

William R. Wilmarth, 773-42A

Publication Date: December 5, 2000

Westinghouse Savannah River Company

Savannah River Site

Aiken, SC 29808

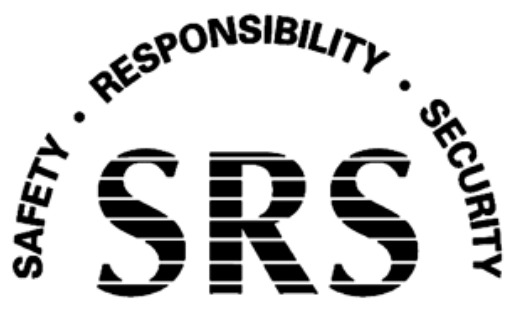

Prepared for the U.S. Department of Energy under Contract No. DE-AC09-96SR18500 
This document was prepared in conjunction with work accomplished under Contract No.

DE-AC09-96SR18500 with the U.S. Department of Energy.

\section{DISCLAIMER}

This report was prepared as an account of work sponsored by an agency of the United States Government. Neither the United States Government nor any agency thereof, nor any of their employees, makes any warranty, express or implied, or assumes any legal liability or responsibility for the accuracy, completeness, or usefulness of any information, apparatus, product or process disclosed, or represents that its use would not infringe privately owned rights. Reference herein to any specific commercial product, process or service by trade name, trademark, manufacturer, or otherwise does not necessarily constitute or imply its endorsement, recommendation, or favoring by the United States Government or any agency

thereof. The views and opinions of authors expressed herein do not necessarily state or reflect those of the United States Government or any agency thereof.

This report has been reproduced directly from the best available copy.

Available for sale to the public, in paper, from: U.S. Department of Commerce, National Technical Information Service, 5285 Port Royal Road, Springfield, VA 22161, phone: (800)

553-6847, fax: (703) 605-6900, email: orders@ntis.fedworld.gov online ordering: http://www.ntis.gov/ordering.htm

Available electronically at http://www.doe.gov/bridge

Available for a processing fee to U.S. Department of Energy and its contractors, in paper, from: U.S. Department of Energy, Office of Scientific and Technical Information, P.O. Box 62, Oak Ridge, TN 37831-0062, phone: (865 ) 576-8401, fax: (865) 576-5728, email: reports@ adonis.osti.gov 
WSRC-TR-2000-00506

SRT-RPP-2001-00006

BNF-003-98-0317

Strontium-Transuranic Precipitation and

Crossflow Filtration of 241-AN-102 Large C

\section{APPROVALS}

Date:

Charles A. Nash, Author (WPT Group/SRTC)

Date:

Hiroshi H. Saito, Co-author (WPT Group/SRTC)

Date:

Bill R. Wilmarth, Co-author (WPT Group/SRTC)

Date:

Technical Reviewer 


\section{Table of Contents}

\subsection{SUMMARY..............................................................................................................................1}

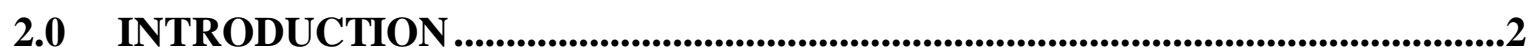

3.0 EXPERIMENTAL AND RESULTS............................................................................2

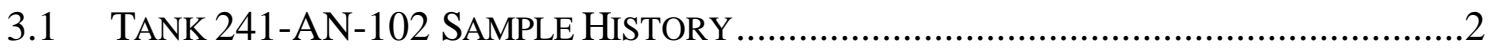

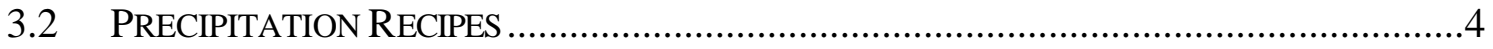

3.3 PRECIPITATION/FILTRATION BATCH HISTORY …………...................................6

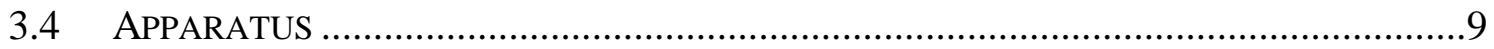

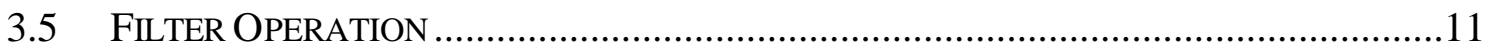

3.6 PRECIPITATION CHEMISTRY RESULTS …………..................................................

3.6.1 Decontamination - Desired Targets for the Process ......................................11

3.6.2 Decontamination - Strontium ................................................................... 12

3.6.3 Decontamination - Transuranics.............................................................

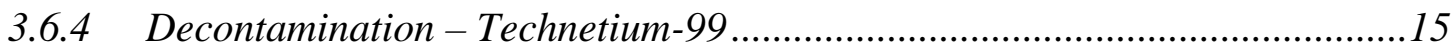

3.6.5 Components Showing Little Removal...........................................................16

3.6.6 Analyses of Final Filtrate Products........................................................19

3.6.7 Chemical Analysis of Slurry Washing ……………....................................20

3.6.8 Filter Cleaning - Flush Solution Compositions...............................................23

3.6.9 Final Compositions of Major Products of the Campaign................................25

3.6.10 Observations on Post Precipitation …………………………………….....25

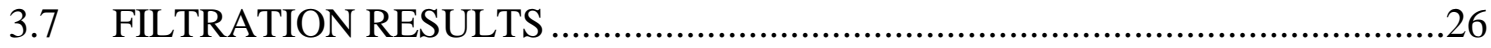

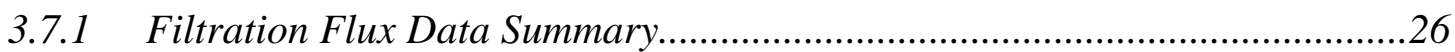

3.7.2 Pre- and Post-Run Clean Water Fluxes.................................................27

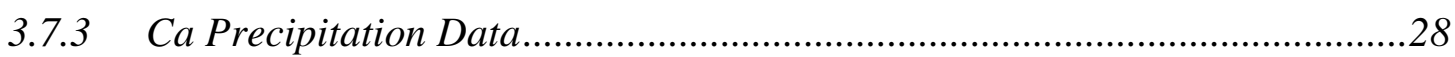

3.7.4 High Insoluble Solids Concentration Flux Data..............................................30

3.7.5 Insoluble Solids Content and Effect of Backpulse.............................................

3.7.6 Product Data Comparisons.........................................................................32

3.7.7 Reduced Reagent Precipitation Batch.........................................................36

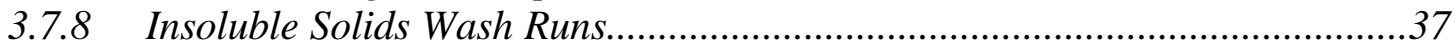

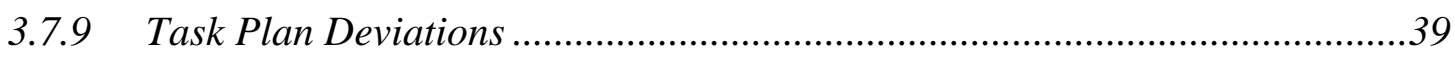

4.0 CONCLUSIONS..........................................................................................................40

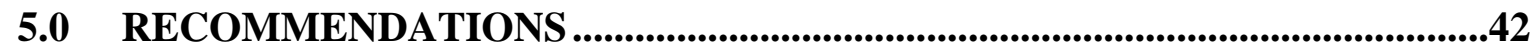

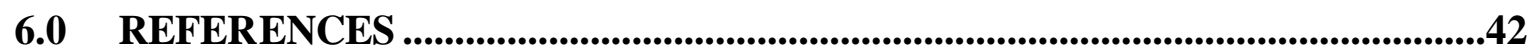




\section{Figures}

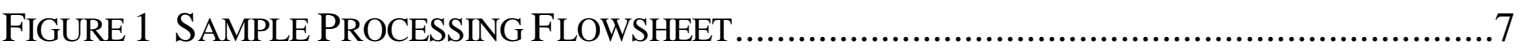

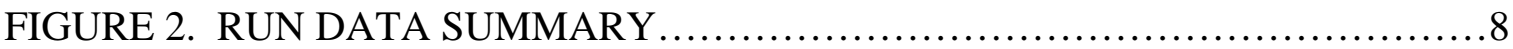

FigURE 3. CELLS FILTER UNIT IN A NONRADIOACTIVE LABORATORY …………...........10

FIGURE 4 STRONTIUM-90 LEVEL IN FILTRATES ............................................................13

FIGURE 5 DECONTAMINATION BASED ON TOTAL STRONTIUM............................................13

FIGURE 6 TRANSURANIC ACTIVITY IN LARGE C (AN102) FILTRATES ..................................14

FiguRE 7 TECHNETIUM LEVELS IN PRODUCT FILTRATE SAMPLES .......................................16

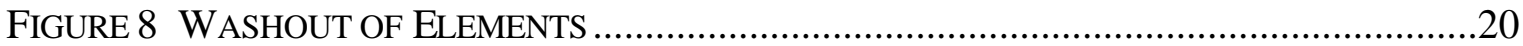

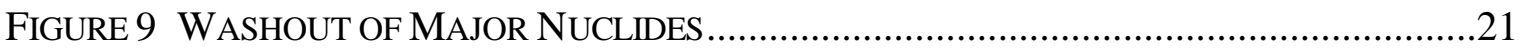

FIGURE 10 ELEMENTS FOUND IN FLUSH SOLUTIONS ......................................................24

FIGURE 11 ACTIVE ELEMENTS IN FLUSH LIQUIDS .............................................................24

FigURE 12 CLEAN WATER FLUXES OF THE CUF FROM THE FILTRATION OF DEIONIZED WATER BEFORE AND AFTER PRECIPITATED LARGE C FILTRATION...................................27

FIGURE 13 CLEAN WATER PERMEANCES OF THE CUF FROM THE FILTRATION OF DEIONIZED WATER BEFORE AND AFTER PRECIPITATED LARGE C FILTRATION...................................27

FigURE 14 PERMEATE FLUX DATA FROM THE CA/SR NITRATE AND PERMANGANATE

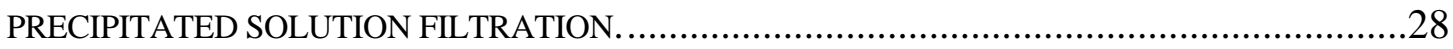

FIGURE 15 PERMEATE FLUX DATA FROM CA/SR NITRATE AND PERMANGANATE PRECIPITATE FILTRATION AS AFFECTED BY FILTER TRANSMEMBRANE PRESSURE, ...............................29

FIGURE 16 PERMEATE FLUX DATA FROM CA/SR NITRATE AND PERMANGANATE PRECIPITATE FILTRATION AS AFFECTED BY FILTER AXIAL VELOCITY.

FigURE 17 PERMEANCE DATA FROM THE CA/SR NITRATE AND PERMANGANATE PRECIPITATED SOLUTION FILTRATION.

FIGURE 18 PERMEATE FLUX AND PERMEANCE FROM FILTRATION OF 13.9 WT.\% INSOLUBLE SOLIDS FLUID AFTER SUCCESSIVE SR(NO $\left(\mathrm{NO}_{3}\right)_{2} / \mathrm{NAMNO}_{4}$ PRECIPITATIONS.

FIGURE 19 PERMEATE FLUX DURING FILTRATION OF BATCH 7 AS AFFECTED BY HIGH INSOLUBLE SOLIDS CONTENT, AND AS AFFECTED BY RESTART WITHOUT BACKPULSE TMP $=2.06$ BAR $(30 \mathrm{PSI})$, AXIAL VELOCITY $=4.63 \mathrm{M} / \mathrm{s}(15 \mathrm{FT} / \mathrm{S})$, NOMINALLY........

FIGURE 20 PERMEATE FLUX DURING FILTRATION OF BATCH 4 AS AFFECTED BY HIGH INSOLUBLE SOLIDS CONTENT, AND AS AFFECTED BY RESTART WITHOUT BACKPULSE TMP $=3.45$ BAR (50 PSI), AXIAL VELOCITY $=3.72 \mathrm{M} / \mathrm{s}(12 \mathrm{FT} / \mathrm{s})$, NOMINALLY

FIGURE 21 PERMEATE FLUX DURING FILTRATION OF BATCH 2 AS AFFECTED BY LOW INSOLUBLE SOLIDS CONTENT, AND AS AFFECTED BY RESTART WITHOUT BACKPULSE TMP $=3.45$ BAR (50 PSI), AXIAL VELOCITY $=3.72 \mathrm{M} / \mathrm{S}(12 \mathrm{FT} / \mathrm{S})$, NOMINALLY $\ldots \ldots \ldots \ldots . . .35$

FIGURE 22 PERMEATE FLUX DATA AT THE BEGINNING OF BATCH 3 FILTRATION. TMP = 3.45 BAR (50 PSI), $3.75 \mathrm{M} / \mathrm{s}$ (12 FT/S) AXIAL VELOCITY, NOMINAL

FIGURE 23 PERMEATE FLUX COMPARISON BETWEEN FLUX DATA TAKEN AT HIGH INSOLUBLE SOLIDS CONCENTRATION AND AT THE END OF BATCH 7. TMP $=2.06$ BAR (30 PSI), 4.63 (15 FT/S) NOMINAL AXIAL VELOCITY.

FIGURE 24 PERMEATE FLUX AND PERMEANCE OF EACH $0.01 \mathrm{M}$ NAOH SOLUTION WASH VS. THE END OF FILTRATION RESULTS. 


\section{WSRC-TR-2000-00506 \\ SRT-RPP-2001-00006 \\ BNF-003-98-0317}

\section{Tables}

TABLE 1 SAMPLE IDENTIFICATIONS FOR SMALL C COMPOSITE ................................................

TABLE 2 SODIUM LEVEL ADJUSTMENT IN TANK 241-AN-102 SAMPLES ................................

TABle 3 CONCENTRATION RAISE TARGETS FOR THE TwO SR/TRU PRECIPITATION RECIPES

TABLE 4 CONCENTRATION OF DILUTED FEED AND ADJUSTED FEED (ASSUMING IDEAL

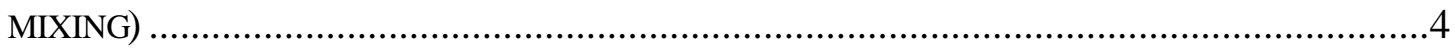

TABLE 5 SR/TRU PRECIPITATION RECIPES - CALCULATED VOLUMES OF SOLUTION .............5

TABLE 6 SR/TRU PRECIPITATION RECIPE FINAL CONCENTRATION OF TARGET SPECIES TARGET VS. EXPECTED FOR EACH PRECIPITATION RECIPE...............................................

TABLE 7 SODIUM LEVEL ADJUSTMENT IN TANK 241-AN-102 SAMPLES ..............................6

TABLE 8 DECONTAMINATION FACTOR FOR TRANSURANICS IN LARGE C FILTRATE SAMPLES

TABLE 9 TABLE OF SLURRY-BASED DECONTAMINATION FACTORS FOR METALLIC ELEMENTS ..........................................................................................

TABle 10 Elemental SPlit aCross THE FILTER - ICP-ES DATA, SEVERAL W ORKS........18

TABLE 11 RADIOCHEMICAL DATA FOR FINAL PRODUCT COMPOSITE …………………........19

TABLE 12 AVERAGe InITIAL CONCENTRATION OF FILTRATE PRODUCT, LAST THREE

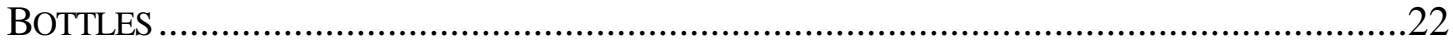

TABLE 13. SUMMARY OF CUF FLUX DATA ……………….................................................26

TABLE 14. MEASURED VS. CALCULATED INSOLUBLE SOLIDS CONTENT FOR CUF ...............33

TABLE 15 TEChNICAL TASK Plan (TABLE 2) WITH DEVIATIONS NOTED IN PARENTHESES 40 


\section{WSRC-TR-2000-00506}

SRT-RPP-2001-00006

BNF-003-98-0317

\subsection{SUMMARY}

This work provides an important confirmation of the new strontium/permanganate precipitation process to achieve both acceptable filterability and decontamination for Envelope C (Tanks 241-AN-102 and 241-AN-107) wastes to be treated by the Hanford River Protection Project. As a bench-scale demonstration, a series of seven precipitation batches and crossflow filtration campaigns were performed to remove strontium-90 and transuranics from 16.5 liters of Tank 241-AN-102 "Large C" supernatant liquid containing entrained solids. In each batch, the Large $C$ sample was caustic adjusted, strontium and permanganate precipitated, and crossflow filtered with entrained solids using a 2-foot long, 3/8" internal diameter, 0.1 micron pore size Mott crossflow filter tube. Test ranges for the transmembrane pressures and crossflow velocities were in the range of 30 to $70 \mathrm{psig}$ ( 2.07 to $4.83 \mathrm{bar}$ ) and 9 to $15 \mathrm{ft} / \mathrm{s}(2.7$ to $4.6 \mathrm{~m} / \mathrm{s}$ ), respectively.

The filtrate product was decontaminated for strontium by a factor exceeding 40 to produce a $1.0 \mu \mathrm{Ci} / \mathrm{ml}$ product at $5.8 \mathrm{M}$ sodium, far below the $8.4 \mu \mathrm{Ci} / \mathrm{ml}$ maximum at 6.0 $\mathrm{M} \mathrm{Na}$ design specification. This work also showed that strontium levels are reduced by simple isotopic dilution and strontium decontamination factors can be predicted a priori. Transuranics decontamination factors between 2.9 and 12.4 were achieved to produce filtrates below the $0.109 \mu \mathrm{Ci} / \mathrm{ml}$ limit. This precipitation process is also metal selective where, for example, technetium-99 was not removed and was favorably non-selective towards aluminum. Washing of the high insoluble solids slurry with inhibited water showed simple dilution effects on most metals, although there was evidence that plutonium, calcium, strontium, and lead did leach somewhat. Lastly, no post-treatment precipitation in the product filtrate was observed after several days of storage in the SRTC Shielded Cells.

The slurry produced from the strontium/permanganate precipitation process was crossflow filterable producing fluxes similar to the design basis "optimum" of 3.8 $\mathrm{m}^{3} / \mathrm{m}^{2} *$ day $\left(0.065 \mathrm{gpm} / \mathrm{ft}^{2}\right)$ for a Tank AN-102 waste with $2 \%$ insoluble solids. At 1.5 wt\% insoluble solids, increasing transmembrane pressure and increasing fluid axial velocity improved filter fluxes, with permeance maximized at lower transmembrane pressure and high axial velocity. Lower transmembrane pressure and higher axial velocities improved both filter fluxes and permeances at high insoluble solids levels (12$14 \mathrm{wt} \%$ ) and when washing accumulated solids in the filter loop after Hanford material filtration. No significant differences in filter fluxes was found when the calcium nitratestrontium nitrate-sodium permanganate data obtained in this study was compared with literature data for strontium nitrate-sodium permanganate strike. Lastly, a Cells Unit Filter operation shutdown and restart was found to improve filter flux like a backpulse up to approximately $7 \mathrm{wt} \%$ insoluble solids loadings.

Based on this work, further work is recommended to examine the possibility of meeting decontamination limits with reduced reagent levels. As decontamination far exceeded requirements, the total added oxide sent to the High Level Waste melter may be reduced. 
WSRC-TR-2000-00506

SRT-RPP-2001-00006

BNF-003-98-0317

Optimization of filtration rates by varying backpulse frequency was not part of the scope of this work and is also suggested.

\subsection{INTRODUCTION}

A scoping study by Herting $^{1}$ showed the efficacy of a strontium nitrate-ferric nitrate strike on the removal of strontium-90 and transuranics from caustic adjusted Hanford wastes. However, the ferric hydroxide precipitation resulting from this chemistry created filtration difficulties, leading to the discovery of a filterable calcium nitrate-strontium nitrate-sodium permanganate strike during an investigation of alternate chemistries with simulated waste at the Savannah River Technology Center (SRTC) ${ }^{2}$. An investigation at the Pacific Northwest National Laboratory (PNNL) also demonstrated sufficient removal efficiencies and filterability using a simpler strontium nitrate-sodium permanganate strike $^{3}$. Based on this initial work, a small scale study with radioactive Hanford AN-102 (Envelope C) waste was conducted using lower strontium and permanganate quantities, and demonstrated acceptable filterability and Sr/TRU removal ${ }^{4}$. This new process reduces strontium- 90 by isotopic dilution with inactive strontium nitrate addition through precipitation of strontium carbonate, with permanganate precipitating as manganese dioxide providing high lanthanide and transuranic decontamination. A detailed literature background supporting the new process is given in the second reference.

The purpose for this work was to demonstrate the efficacy of this new process on a bench-scale in semi-continuous operation, and to optimize filtration performance. This investigation, which represents the second radioactive crossflow filter testing of the strontium/permanganate process for Envelope C, was conducted according to a Technical Task Plan ${ }^{5}$ written in response to the cited Task Specification ${ }^{6}$. This work also served as a confirmation of the filterability of the AN-102 supernatant liquid after precipitation without prefiltration to remove entrained solids. SRTC and PNNL have found that the entrained solids in Envelope $\mathrm{C}$ have been very difficult to filter and have activities sufficiently high for classification as High Level Waste.

\subsection{EXPERIMENTAL AND RESULTS}

\subsection{Tank 241-AN-102 Sample History}

The Hanford site contractor obtained approximately 14.25-liters of waste solution from tank 241-AN-102 during 1998. The waste samples were obtained by lowering sample bottles into the liquid phase of the waste, and are denoted as "grab samples" since the contents of Tank 241-AN-102 were not agitated prior to or during the sampling event. The Hanford site contractor then packaged these samples for shipment which the SRTC received in four separate deliveries from October through December, 1998. Summary information on the received samples is listed in Table 1.

Initially, each shipment of 8 samples were composited into $4 \mathrm{~L}$ polyethylene bottles. From the first shipment composite, approximately $1.5 \mathrm{~L}$ was withdrawn to create the 
"Small C" sample. The remainder of "grab samples" was composited in a $25 \mathrm{~L}$ carboy, mixed well, and then characterized as the "Large C" sample as reported by Hay". Of the composited sample, 10.1 L was then split into seven 4-liter polyethylene bottles and each bottle was diluted initially using inhibited water $(0.01 \mathrm{M} \mathrm{NaOH})$ to within $5 \%$ (see Table 12 of Hay's report) of the $6 \mathrm{M}$ sodium target from above, and analyzed by ICP-ES. As solids dissolution may have caused an initial increase over the target, a second dilution was subsequently made to produce a $\sim 16.4 \mathrm{~L}$ total final volume, and the results of this process are summarized in Table 2.

Table 1 Sample Identifications for Small C Composite

\begin{tabular}{|c|c|c|c|}
\hline Jar Label & $\begin{array}{c}\text { Number } \\
\text { of Jars }\end{array}$ & $\begin{array}{c}\text { Sample } \\
\text { Date }\end{array}$ & Sample Type \\
\hline $\begin{array}{c}\text { 2AN 98-43 to } \\
\text { 2AN 98-48 }\end{array}$ & 6 & $07 / 21 / 98$ & $\begin{array}{c}\text { Unaltered Grab } \\
\text { Sample }\end{array}$ \\
\hline $\begin{array}{c}\text { 2AN 98-49 to } \\
\text { 2AN 98-54 }\end{array}$ & 6 & $07 / 22 / 98$ & $\begin{array}{c}\text { Unaltered Grab } \\
\text { Sample }\end{array}$ \\
\hline $\begin{array}{c}\text { 2AN 98-58 to } \\
\text { 2AN 98-62 }\end{array}$ & 5 & $08 / 10 / 98$ & $\begin{array}{c}\text { Unaltered Grab } \\
\text { Sample }\end{array}$ \\
\hline $\begin{array}{c}\text { 2AN 98-63 to } \\
\text { 2AN 98-67 }\end{array}$ & 5 & $08 / 11 / 98$ & $\begin{array}{c}\text { Unaltered Grab } \\
\text { Sample }\end{array}$ \\
\hline $\begin{array}{c}\text { 2AN 98-68 to } \\
\text { 2AN 98-72 }\end{array}$ & 5 & $08 / 12 / 98$ & $\begin{array}{c}\text { Unaltered Grab } \\
\text { Sample }\end{array}$ \\
\hline 2AN 98- & 5 & $07 / 21 / 98$ & $\begin{array}{c}\text { Liquid Core } \\
\text { Composite }\end{array}$ \\
\hline
\end{tabular}

Table 2 Sodium Level Adjustment in Tank 241-AN-102 Samples

\begin{tabular}{|l|c|c|c|c|c|c|c|}
\hline Bottle Name Suffix* & Dil-1 & Dil-2 & Dil-3 & Dil-4 & Dil-5 & Dil-6 & Dil-7 \\
\hline $\begin{array}{l}\text { [Na+] after initial } \\
\text { dilution }\end{array}$ & 5.75 & 7.07 & 7.16 & 6.37 & 6.31 & 6.57 & 6.69 \\
\hline Volume, ml & 2700 & 2100 & 2000 & 2400 & 1500 & 2200 & 2300 \\
\hline Total Na+, grams & 357 & 341 & 329 & 352 & 218 & 332 & 354 \\
\hline & & & & & & & \\
\hline $\begin{array}{l}\text { DI water added, ml } \\
\text { (second dilution) }\end{array}$ & 0 & 350 & 375 & 0 & 0 & 200 & 250 \\
\hline New Vol., ml & 2700 & 2450 & 2375 & 2400 & 1500 & 2400 & 2550 \\
\hline Final [Na+], M & 5.75 & 6.06 & 6.03 & 6.37 & 6.31 & 6.02 & 6.04 \\
\hline
\end{tabular}

*All names begin with "BNF-LC100-“, e.g., BNF-LC100-Dil-1.

Total grams sodium $=2283$ grams or 99.3 moles

Total final volume $=16.375$ liters $[$ average sodium molarity $=6.06$ ] 


\subsection{Precipitation Recipes}

Two precipitation recipes were studied in this work to further examine the two successful chemistries identified at PNNL and SRTC: 1) addition of non-radioactive $\operatorname{Sr}\left(\mathrm{NO}_{3}\right)_{2}$ and $\mathrm{NaMnO}_{4}$ to take advantage of high filterability and reasonable $\mathrm{Sr}^{90}$ and TRU removal efficiencies ${ }^{8,9}$, and 2) addition of $\mathrm{Ca}\left(\mathrm{NO}_{3}\right)_{2}$, non-radioactive $\mathrm{Sr}\left(\mathrm{NO}_{3}\right)_{2}$, and $\mathrm{NaMnO}_{4}$ to balance higher removal efficiencies against lower filterabilities associated with $\mathrm{Ca}$ addition ${ }^{10}$. These were added after $\mathrm{pH}$ adjustment using concentrated $\mathrm{NaOH}$.

The concentration of free $\mathrm{OH}-$ and each metal in the final mixture was adjusted upward by the quantities listed in Table 3 based on the most effective formulations known at the time (early November, 1999) at the SRTC ${ }^{11}$. The cation/anion additions were made using $17 \mathrm{M} \mathrm{NaOH}, 1 \mathrm{M} \mathrm{Ca}\left(\mathrm{NO}_{3}\right)_{2}, 1 \mathrm{M} \mathrm{Sr}\left(\mathrm{NO}_{3}\right)_{2}$, and $1 \mathrm{M} \mathrm{NaMnO}_{4}$ solutions, added to the feed solution in that order.

Table 3 Concentration Raise Targets for the Two Sr/TRU Precipitation Recipes

\begin{tabular}{|l|c|c|}
\hline \multirow{2}{*}{ Cation/Anion I Recipe } & \multicolumn{2}{|c|}{ Concentration [M] } \\
\cline { 2 - 3 } & $\mathrm{Ca} / \mathrm{Sr} / \mathrm{MnO}_{4}$ & $\mathrm{Sr} / \mathrm{MnO}_{4}$ \\
\hline Free $\mathrm{OH}$ & 0.875 & 0.875 \\
\hline $\mathrm{Ca}^{2+}$ & 0.008 & ------ \\
\hline $\mathrm{Sr}^{2+}$ & 0.02 & 0.075 \\
\hline $\mathrm{MnO}_{4}^{-}$ & 0.03 & 0.05 \\
\hline
\end{tabular}

Table 4 Concentration of diluted feed and adjusted feed (assuming ideal mixing)

\begin{tabular}{|c|c|c|c|}
\hline \multirow[b]{2}{*}{ Cation/Anion \ Na conc. } & \multicolumn{3}{|c|}{ Concentration $[\mathrm{M}]$} \\
\hline & $\begin{array}{l}\text { 6.4 M Na } \\
\text { (diluted) }\end{array}$ & $\begin{array}{l}6.0 \mathrm{M} \mathrm{Na} \\
\text { (adjusted) }\end{array}$ & $\begin{array}{l}6.0 \mathrm{M} \mathrm{Na} \text { [calc.] } \\
\left(\mathrm{PNNL}, 1998^{12,13}\right)\end{array}$ \\
\hline Free $\mathrm{OH}^{-}$ & $0.817 *$ & $0.763 *$ & 0.0972 \\
\hline $\mathrm{Sr}^{2+}$ & 0 & 0 & 0 \\
\hline $\mathrm{Ca}^{2+}$ & 0.008 & 0.0075 & 0.00782 \\
\hline
\end{tabular}

Analysis of a 241-AN-102 sample after dilution to $6.4 \mathrm{M} \mathrm{Na}$ by $\mathrm{Hay}^{14}$ showed the concentrations of the ions of interest in Table 4. Values relevant to the $6 \mathrm{M} \mathrm{Na}+$ sample (assuming ideal mixing in the calculation) in the current work are shown as well. The last column of Table 4 presents the calculated diluted composition data from the 1998 PNNL analysis of the same grab samples. Micromolar concentrations of Sr-90 observed in both SRTC and PNNL analyses were neglected here. Hay believes the high SRTC free hydroxide result is due to a high bias caused by incomplete carbonate precipitation by the $\mathrm{SrCl}_{2} /$ titration method and/or from the presence of the organic complexing agents. 
WSRC-TR-2000-00506

SRT-RPP-2001-00006

BNF-003-98-0317

Based on the initial concentrations at $6.0 \mathrm{M} \mathrm{Na}$ in Table 4 and the concentration raise targets in Table 3 (target concentration = adjusted feed concentration + Table 3 quantity), quantities of each solution to add per liter of $6.0 \mathrm{M} \mathrm{Na}$ Large C Envelope adjusted feed was calculated by simultaneously solving a set of linear equations, assuming ideal mixing, for each recipe. The results of those calculations based on both SRTC and PNNL initial concentration results are shown in Table 5. Refer to Appendix B for the spreadsheet used for these calculations.

Table 5 Sr/TRU Precipitation Recipes - Calculated volumes of solution addition per liter 6.0 M Na Large C (AN-102) feed

\begin{tabular}{|l|c|c|c|c|}
\hline \multirow{2}{*}{ Solution I Recipe } & \multicolumn{4}{|c|}{ Volume [ml] } \\
\cline { 2 - 5 } & Per SRTC feed composition & \multicolumn{2}{|c|}{ Per PNNL feed composition } \\
\cline { 2 - 5 } & $\mathrm{Ca} / \mathrm{Sr} / \mathrm{MnO}_{4}$ & $\mathrm{Sr} / \mathrm{MnO}_{4}$ & $\mathrm{Ca} / \mathrm{Sr} / \mathrm{MnO}_{4}$ & $\mathrm{Sr} / \mathrm{MnO}_{4}$ \\
\hline $17 \mathrm{M} \mathrm{NaOH}$ & 64.1 & 73.3 & 58.6 & 63.8 \\
\hline $1 \mathrm{M} \mathrm{Sr}\left(\mathrm{NO}_{3}\right)_{2}$ & 22.6 & 92.0 & 22.5 & 91.2 \\
\hline $1 \mathrm{M} \mathrm{NaMnO}_{4}$ & 33.9 & 61.3 & 33.8 & 60.8 \\
\hline $1 \mathrm{M} \mathrm{Ca}\left(\mathrm{NO}_{3}\right)_{2}$ & 10.0 & ----- & 10.0 & ----- \\
\hline
\end{tabular}

Mistakenly, the reagent addition volumes based on the SRTC analytical results were used instead of those based on PNNL results that were thought to be more accurate. Hence, an over-addition of the sodium hydroxide and precipitation reagent solutions resulted. Table 6 shows that the final expected concentrations of each species after addition likely did not change much beyond analytical uncertainty, compared to the target concentrations based on the PNNL feed composition data.

Table 6 Sr/TRU Precipitation Recipe Final Concentration of Target Species Target vs. Expected for Each Precipitation Recipe

\begin{tabular}{|l|c|c|c|c|}
\hline \multirow{2}{*}{ Solution \ Recipe } & \multicolumn{4}{|c|}{ Molarity [M] } \\
\cline { 2 - 5 } & \multicolumn{2}{|c|}{ Target Concentration } & \multicolumn{2}{|c|}{ Expected Concentration } \\
\cline { 2 - 5 } & $\mathrm{Ca} / \mathrm{Sr} / \mathrm{MnO}_{4}$ & $\mathrm{Sr} / \mathrm{MnO}_{4}$ & $\mathrm{Ca} / \mathrm{Sr} / \mathrm{MnO}_{4}$ & $\mathrm{Sr} / \mathrm{MnO}_{4}$ \\
\hline Free OH- & 0.972 & 0.972 & 1.05 & 1.10 \\
\hline $\mathrm{Sr}^{2+}$ & 0.020 & 0.075 & 0.020 & 0.075 \\
\hline $\mathrm{Mn}^{\mathrm{x}}$ & 0.030 & 0.050 & 0.030 & 0.050 \\
\hline $\mathrm{Ca}^{2+}$ & 0.016 & ---- & 0.016 & ---- \\
\hline $\mathrm{Na}$ (resulting) & 6.22 & 5.83 & 6.27 & 5.91 \\
\hline
\end{tabular}

The deviation in the recipe calculation did not affect the resulting strontium and manganese concentrations, increases sodium concentration $0.05-0.08 \mathrm{M}$, and increases free hydroxide concentration by $0.07-0.12 \mathrm{M}$. While higher than the requested recipe, the resulting added free hydroxide is still very close to Rosencrance's recommended maximum addition of $1.0 \mathrm{M}$ free hydroxide ${ }^{15}$ found in his statistically-designed experiments with another sample of 241-AN-102. 


\subsection{Precipitation/Filtration Batch History}

The seven partially-filled 4 liter carboys were used for seven precipitation batches, and close but not exactly on a one-to-one basis. As volumes in the carboys were approximate, a few hundred milliliters of feed left in the previous carboy was sometimes carried forward to the next batch. Batches 6 and 7 (Table 7) are the only batches with a significant mixing of different carboys. The best estimate for the actual quantities of each carboy fed into each of the seven precipitation batches is listed in Table 7.

The measured sodium levels at the bottom of Table 7 show that final dilution to the desired $6 \mathrm{M}$ sodium level did very well. All bottles were within the $+/-10 \%$ analytical error for sodium measurement.

As solutions cannot easily be quantified and poured in the Shielded Cells where the CUF was operated, precipitation solutions were pre-measured and placed into individual bottles for one-time use. The pre-measured quantities used and listed in Appendix A were calculated based on the original experimental design volumes of $1.2 \mathrm{~L}$ and $2.4 \mathrm{~L}$ batch sizes rather than the actual volumes. As the second dilutions performed by Hay made the total amount of feed actually received larger than the $\left(1.2+6^{*} 2.4=15.6\right.$ liter $)$ plan (Figure 1), calculated final target ion concentrations (Table 7) through addition of the precipitating agents was slightly lower than planned. The process of adding these precipitation solutions raised the volume to be filtered from the approximately $16.5 \mathrm{~L}$ of 6.0 M Na Tank AN-102 supernatant liquid to nearly 19.8 L total precipitated slurry.

Table 7 Sodium Level Adjustment in Tank 241-AN-102 Samples

\begin{tabular}{|c|c|c|c|c|c|c|c|}
\hline Precipitation batch \# & 1 & 2 & 3 & 4 & 5 & 6 & 7 \\
\hline $\begin{array}{l}\sim 6.0 \mathrm{M} \mathrm{Na} \mathrm{AN}-102 \\
\text { volume (L) }\end{array}$ & 1.5 & 2.4 & 2.7 & 2.4 & 2.55 & $\begin{array}{c}1.7 \\
(+0.7 \mathrm{~L} \\
\text { CUF conc.) } \\
\end{array}$ & $\begin{array}{c}3.1 \\
(0.6+2.5)\end{array}$ \\
\hline $\begin{array}{l}\text { AN- } 102+\text { precipitants } \\
\text { volume }(\mathrm{L})\end{array}$ & 1.66 & 2.94 & 3.24 & 2.94 & 3.09 & 2.2 & 3.64 \\
\hline Calculated $\mathrm{Na}$ & 6.50 & 6.21 & 5.71 & 5.92 & 5.94 & 5.93 & 5.96 \\
\hline Calculated Free $\mathrm{OH}^{-}$ & 0.88 & 1.10 & 1.00 & 1.10 & 1.05 & 1.32 & 0.90 \\
\hline Calculated $\mathrm{Sr}^{2+}$ & 0.016 & 0.075 & 0.068 & 0.075 & 0.071 & 0.040 & 0.061 \\
\hline Calculated $\mathrm{Mn}^{\mathrm{x}+}$ & 0.025 & 0.050 & 0.045 & 0.050 & 0.048 & 0.041 & 0.040 \\
\hline Calculated $\mathrm{Ca}^{2+}$ & 0.014 & ----- & ----- & ---- & ---- & ---- & ---- \\
\hline Bottle Used Suffix* & -DIL5 & -DIL4 & -DIL1 & -DIL6 & -DIL7 & -DIL3 & -DIL2 \\
\hline Bottle Na+ molarity & 6.31 & 6.37 & 5.75 & 6.02 & 6.04 & 6.06 & 6.03 \\
\hline
\end{tabular}

*All names begin with "BNF-LC100-“, e.g., BNF-LC100-Dil-1. 
WSRC-TR-2000-00506

SRT-RPP-2001-00006

BNF-003-98-0317

Batch 1

$\mathrm{NaOH}, \mathrm{Ca}(\mathrm{NO} 3) 2$

$\mathrm{Sr}(\mathrm{NO} 3) 2$, Permanganate

First $600 \mathrm{ml}$

Initial Input

Sr(NO3)2, Permanganate

of product

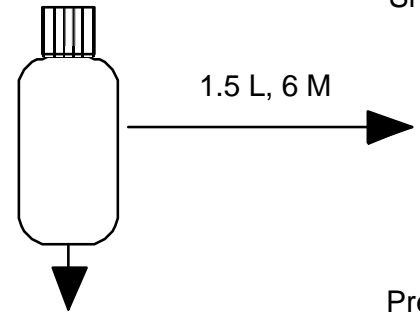

Precipitation

Duplicate Samples

(1)
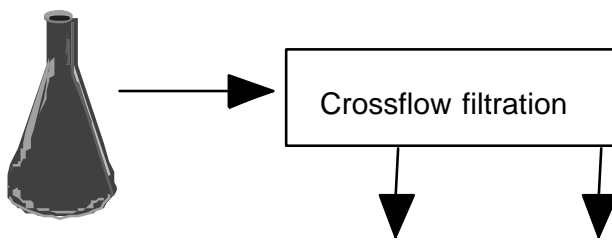

Sample Sample

Conc. \& Filt Conc. \& Filt

halfway

Batches 2-7

through

at end

III

$\mathrm{NaOH}, \mathrm{Sr}(\mathrm{NO} 3) 2$

Continuing Input

Permanganate

Precipitate
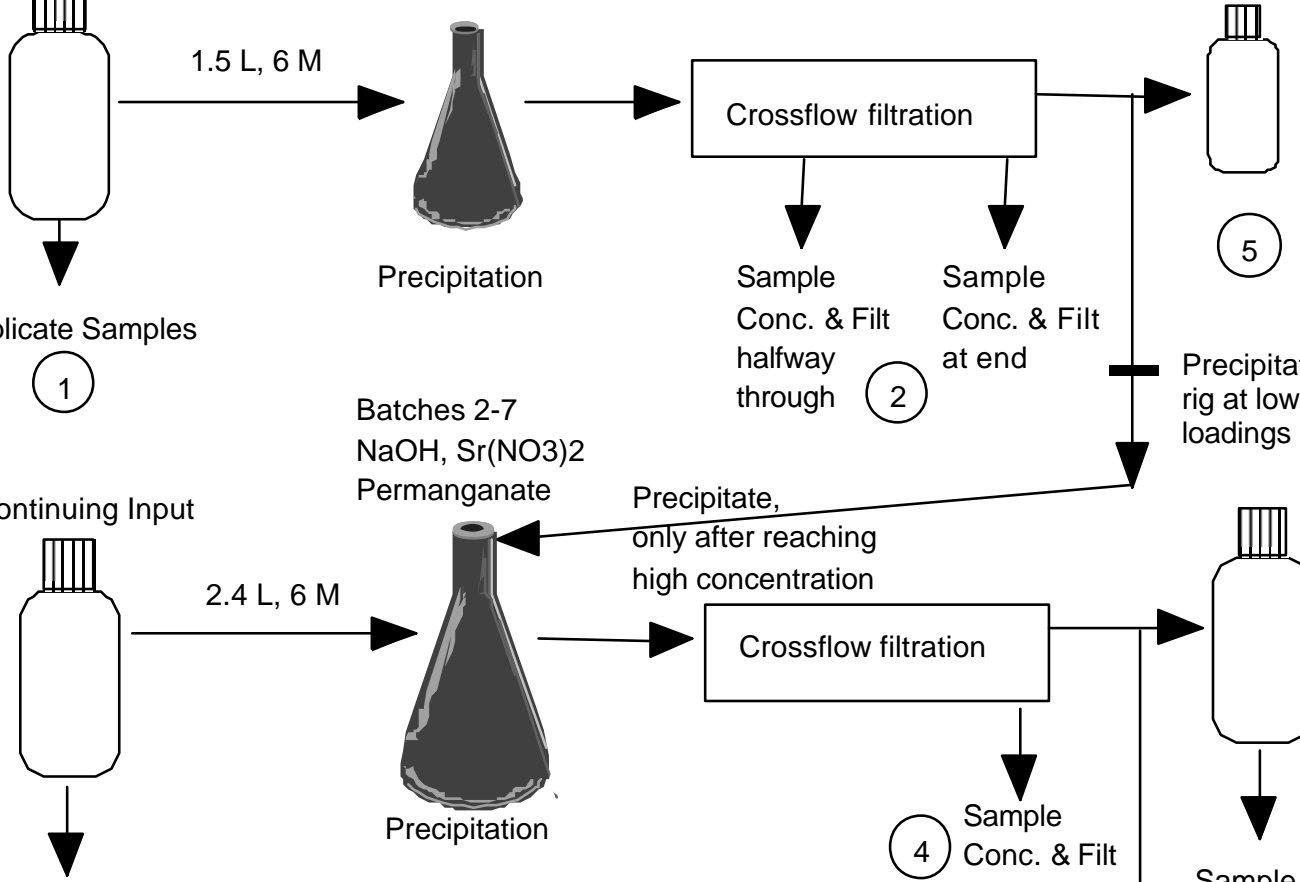

1 Sample

per 3 liters

(3)

only after reaching

(2)

\begin{tabular}{l|l} 
Precipitate left in \\
rig at lower solids
\end{tabular} rig at lower solids loadings

$2.4 \mathrm{~L}, 6 \mathrm{M}$

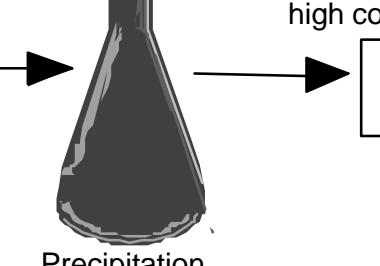

Precipitation

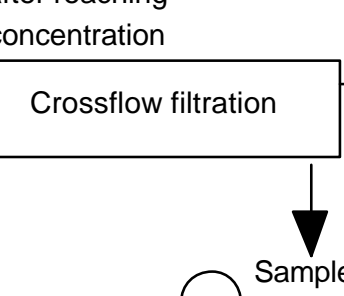

(4) Conc. \& Filt at end
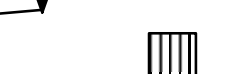

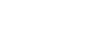




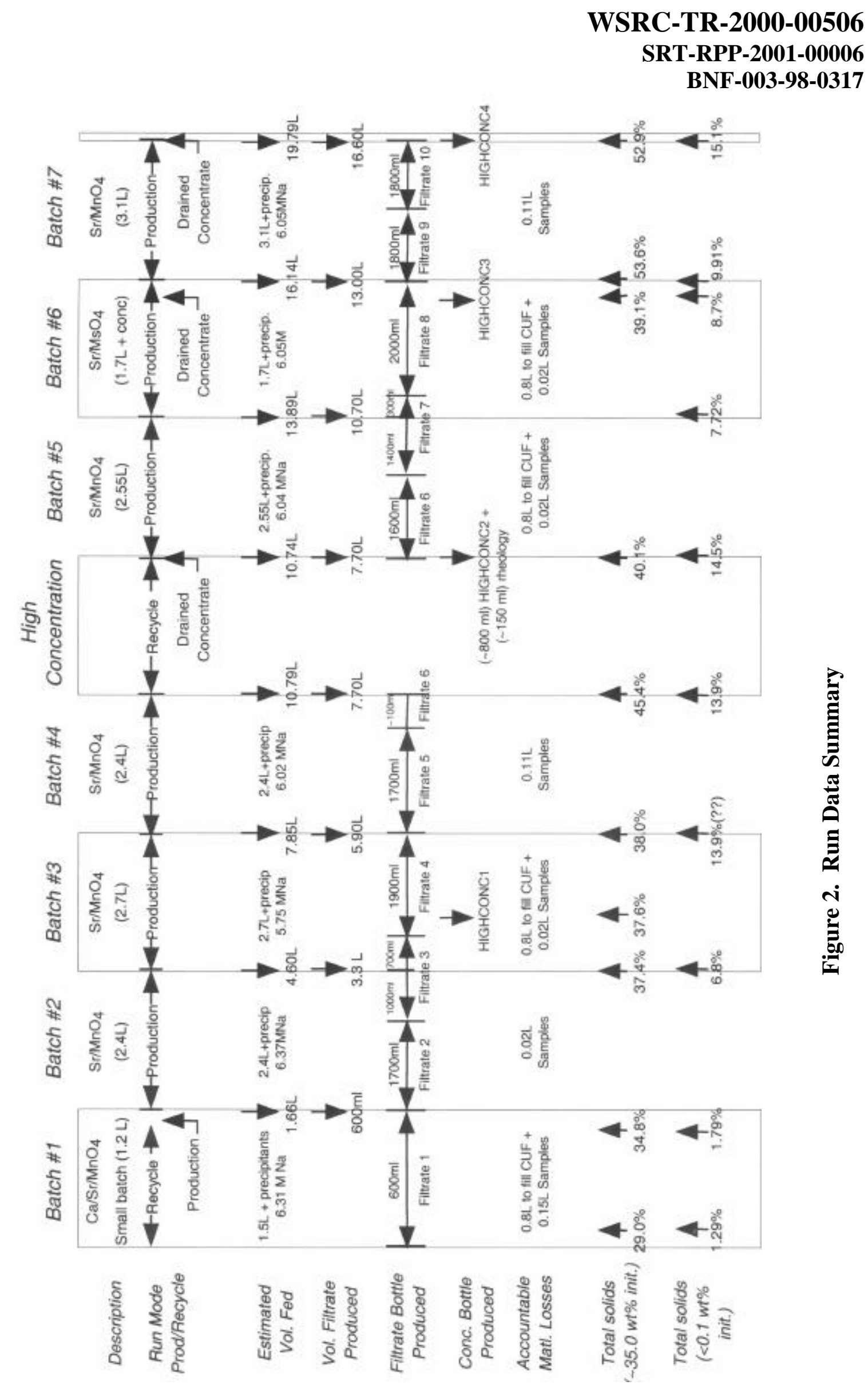




\section{WSRC-TR-2000-00506}

SRT-RPP-2001-00006

BNF-003-98-0317

Figure 1 also shows the process flow and sampling. The Run Data summary (Figure 2) lists in graphical form the information in Table 7 and Figure 1, as well as the product filtrate bottles produced from each precipitation and filtration batch, when the crossflow filter unit was emptied of high insoluble solids content slurry due to low filtration fluxes, and other relevant operation and experiment material balance information.

Generally, the Cells Unit Filter (CUF) crossflow filter unit was operated by semicontinuously adding precipitated slurry as filtrate (or permeate) was produced continuously, allowing insoluble solids to accumulate in the filter loop. When pump and filter performance seriously deteriorated, the CUF was emptied (during Batch 3, before Batch 5, and during Batch 6) before precipitated feed material was added and filtration operations continued. At the end of Batch 7, the accumulated solids were washed in four batches by semi-continuously feeding $600 \mathrm{ml}$ aliquots of inhibited water $(0.01 \mathrm{M} \mathrm{NaOH})$ as filtrate was produced continuously.

After the fourth wash campaign the washed solids/slurry was drained from the CUF rig as well as possible using the drain valves and briefly running the pump. The CUF was then flushed out using deionized (DI) water, then $1 \mathrm{M}$ nitric acid, and DI water rinses. Then post-experiment clean water fluxes were lastly taken. Caustic cleaning solution was not used.

\subsection{Apparatus}

Crossflow filtration is a process where a slurry concentrate passes down a porous tube or channel under pressure, forcing permeate through the walls of the channel and at the same time sweeping concentrated solid cake off the filter medium. The process stands in contrast to dead-end filtration where the cake continues to build on the porous medium. Backpulsing of a crossflow filter (short reversal of the pressure across the medium) reverses the filtrate flow momentarily for extended cake removal so that filter flux is boosted.

Crossflow filtration was performed with a Cells Unit Filter (CUF) rig that was set up in Cell 16, B-Block, at SRTC. Figure 3 shows the unit without cooling tubes connected to the heat exchanger for clarity. Feed from the reservoir at the left goes to a progressive cavity pump. The pump is operated at variable speed by controlling air pressure to the air motor that drives it. Liquid is pumped through a magnetic flowmeter and heat exchanger that removes pump heat. It then passes down the center of a crossflow filter of 2-foot porous length. A throttle valve downstream drops fluid pressure back to atmospheric.

A 0.1 micron-pore Mott filter tube manufactured for "liquid" service was used in this work. The cold CUF work (ref. 1) found that Mott makes different sintered 0.1 micron stainless steel for "liquid" and "gas" service and that the "liquid" style is a requirement for our work. The filter has a two-foot active length, 3/8" ID bore, and 1/16" wall thickness. The filter elements planned for use in the RPP-WTP are also 0.1 micron-pore 
WSRC-TR-2000-00506

SRT-RPP-2001-00006

BNF-003-98-0317

size Mott filter tubes. However, the RPP-WTP filter elements will be approximately 80 inches in length.

Figure 3. Cells Filter Unit in a Nonradioactive Laboratory

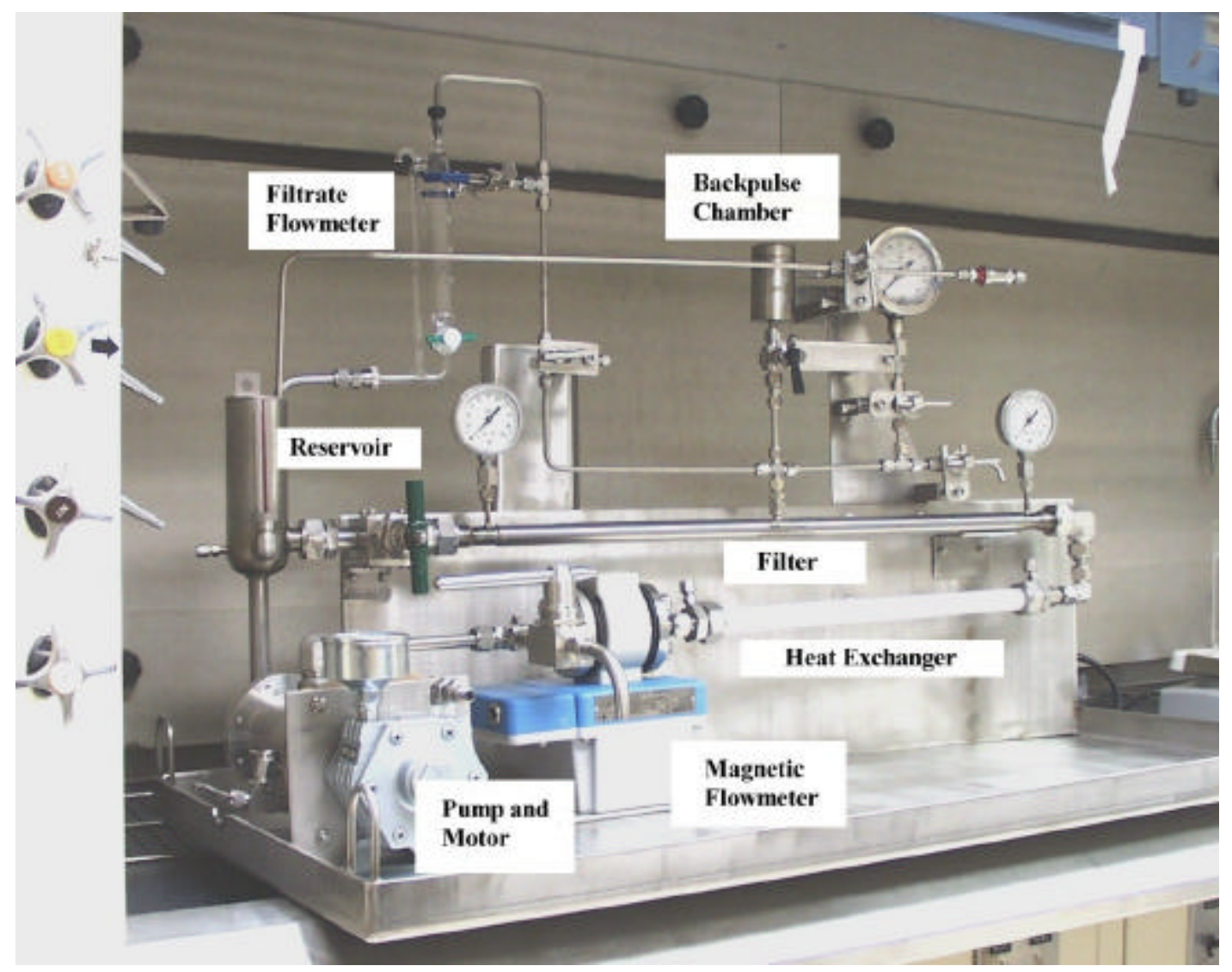

Filtrate production was measured with a graduated sightglass and stopwatch. A simple backpulse system can be charged with filtrate. Compressed air stored in the filtrate chamber forces reverse flow upon the filter medium. Standard Bourdon-type pressure gauges indicate pressure. A thermocouple mounted near the bottom of the reservoir measures slurry temperature directly. Details of the CUF are documented on six approved engineering drawings. ${ }^{16}$

The filter in this work was a 3/8-inch internal diameter, 2-foot long Mott Metallurgical sintered stainless steel filter. The nominal pore size was 0.1 micron. The single filter tube was mounted in a stainless steel housing of welded construction. 


\subsection{Filter Operation}

General operation of the CUF follows an SRTC procedure. ${ }^{17}$ Activities and data are recorded in a controlled laboratory notebook. ${ }^{18}$ The rig is first cleaned by circulation of $1 \mathrm{M}$ nitric acid, $1 \mathrm{M}$ sodium hydroxide, or deionized water. These filter cleaning fluids were prefiltered with 0.22 micron nylon filters before use. $1 \mathrm{M}$ sodium hydroxide was not used in the current work - only $1 \mathrm{M}$ nitric acid with DI water flushes before and after were used for cleaning.

Clean water fluxes were taken after the rig was flushed with cleaning fluids. Transmembrane pressures were between 5 and 20 psid and fluxes were measured for periods of 20 minutes or more per the TTP, after initial backpulsing.

Operation of the CUF involved the following routine:

1. Filtrate was generated to fill the backpulse chamber. The chamber was airpressurized to provide 45 psid overpressure. Filter concentrate pressure was reduced to a few psig for best backpulse effectiveness.

2. Two backpulses were performed before each set of conditions was run.

3. Conditions were set after the second backpulse while the filtrate valve was kept closed.

4. Each run started when the filtrate valve was opened slowly. Slowness was controlled by watching reduction of filtrate side pressure while the needle valve was opened.

5. Samples of concentrate and filtrate were taken at the beginning, middle, and end of the campaign.

\section{RESULTS AND DISCUSSION}

\subsection{Precipitation Chemistry Results}

\subsubsection{Decontamination - Desired Targets for the Process}

The purpose of the precipitation/filtration process is to decontaminate the waste entering the plant so the bulk of the mass, a liquid stream, will produce immobilized low-activity waste (ILAW) glass when vitrified. The transuranic limit here is $100 \eta \mathrm{Ci} / \mathrm{gram}$ of glass. For the pretreated AN-102 waste, the target waste sodium oxide loading in the ILAW glass was $17 \mathrm{wt} \%$. This translates to a decontamination of $794 \mathrm{\eta Ci} / \mathrm{gram}$ of sodium or less, or $127 \mathrm{\eta Ci} / \mathrm{ml}$ of 7 molar sodium liquid.

The waste sodium oxide loading in the ILAW glass produced from the pretreated AN102 sample was revised to $11.8 \mathrm{wt} \%$ subsequent to conducting these tests. The waste sodium oxide loading was reduced to avoid the formation of a separate sulfur phase during the vitrification of the pretreated $\mathrm{AN}-102$ waste. The maximum allowable $\mathrm{Sr}-90$ and TRU concentrations in the pretreated $\mathrm{AN}-102$ waste are $13.8 \eta \mathrm{Ci} / \mathrm{ml}$ and $183.9 \eta \mathrm{Ci} / \mathrm{ml}$, respectively for $7 \mathrm{M} \mathrm{Na}$ solution, based on the lower waste sodium oxide 
WSRC-TR-2000-00506

SRT-RPP-2001-00006

BNF-003-98-0317

loading in the ILAW glass. For the 4.82M Na AN-102 sample, the maximum allowable Sr-90 and TRU concentrations in the pretreated AN-102 waste are $9.5 \eta \mathrm{Ci} / \mathrm{ml}$ and $126.6 \eta \mathrm{Ci} / \mathrm{ml}$, respectively

The strontium-90 target is $20 \mathrm{Ci} /$ cubic meter. This translates to an upper strontium level of $9.8 \eta \mathrm{Ci} / \mathrm{ml}$ for the same basis of $7 \mathrm{M}$ sodium liquid.

The filtrate for most of the Large $\mathrm{C}$ campaign was nominally $6 \mathrm{M}$ in sodium. The final composited product from the campaign was $4.82 \mathrm{M}$ in sodium because filtrate from wash water was part of the composite. The limits for transuranics and strontium-90, and comparison with 241-AN-102 liquid are therefore:

\begin{tabular}{|l|l|l|}
\hline Sodium concentration & Total TRU (alpha) & Strontium-90 \\
\hline $6 \mathrm{M}$ Sodium & $109 \eta \mathrm{Ci} / \mathrm{ml}$ & $8.4 \mu \mathrm{Ci} / \mathrm{ml}$ \\
\hline $4.82 \mathrm{M}$ Sodium & $88 \eta \mathrm{Ci} / \mathrm{ml}$ & $6.75 \mu \mathrm{Ci} / \mathrm{ml}$ \\
\hline $6 \mathrm{M} \mathrm{Na}+241-\mathrm{AN}-102$ & $150 \eta \mathrm{Ci} / \mathrm{ml} *$ & $53 \mu \mathrm{Ci} / \mathrm{ml}$ \\
\hline * Excludes $\mathrm{Cm}-244$, which is at uncertain levels because of possible contamination in SRTC shielded cells. \\
\hline
\end{tabular}

\subsubsection{Decontamination - Strontium}

Strontium-90 was tracked throughout the campaign and Figure 4 summarizes the results. The limit above is also shown on Figure 4. Instantaneous samples of filtrate were taken at the completion of each batch of precipitate. They are grab samples taken from the filtrate outlet. In contrast, "Bottle" samples are taken at the end of the filling of each filtrate collection bottle. They are thus more representative of a composite because the filtrate bottle has from 600 to $2000 \mathrm{ml}$ of filtrate product when Bottle samples are taken.

It is seen that the process is robust in removing strontium-90 from the filtrate stream. In Batch \#1, the target added concentration of $\mathrm{Sr}$ was only $0.02 \mathrm{M}$. Calcium has previously been shown not to affect the removal of Sr-90 from Envelope C solutions. Even with this non-conservative level of strontium addition the process output was less than half of the tolerable limit.

A decontamination factor calculated from total strontium (not Sr-90) is shown on the yaxis in Figure 5. This is calculated by dividing $0.075 \mathrm{M}$ by the measured total strontium measured in the filtrate. It would be comparable to the active decontamination factor in the case where isotopic mixing is good during the precipitation and mixing. The typical values of 40 to 50 during the campaign (average of 48) agree with the active data of Figure 4 because the feed Sr-90 activity was $50 \mu \mathrm{Ci} / \mathrm{ml}$. The typical activities of $1 \mu \mathrm{Ci} / \mathrm{ml}$ shown in Figure 4 indicate a decontamination factor of approximately 50 . 


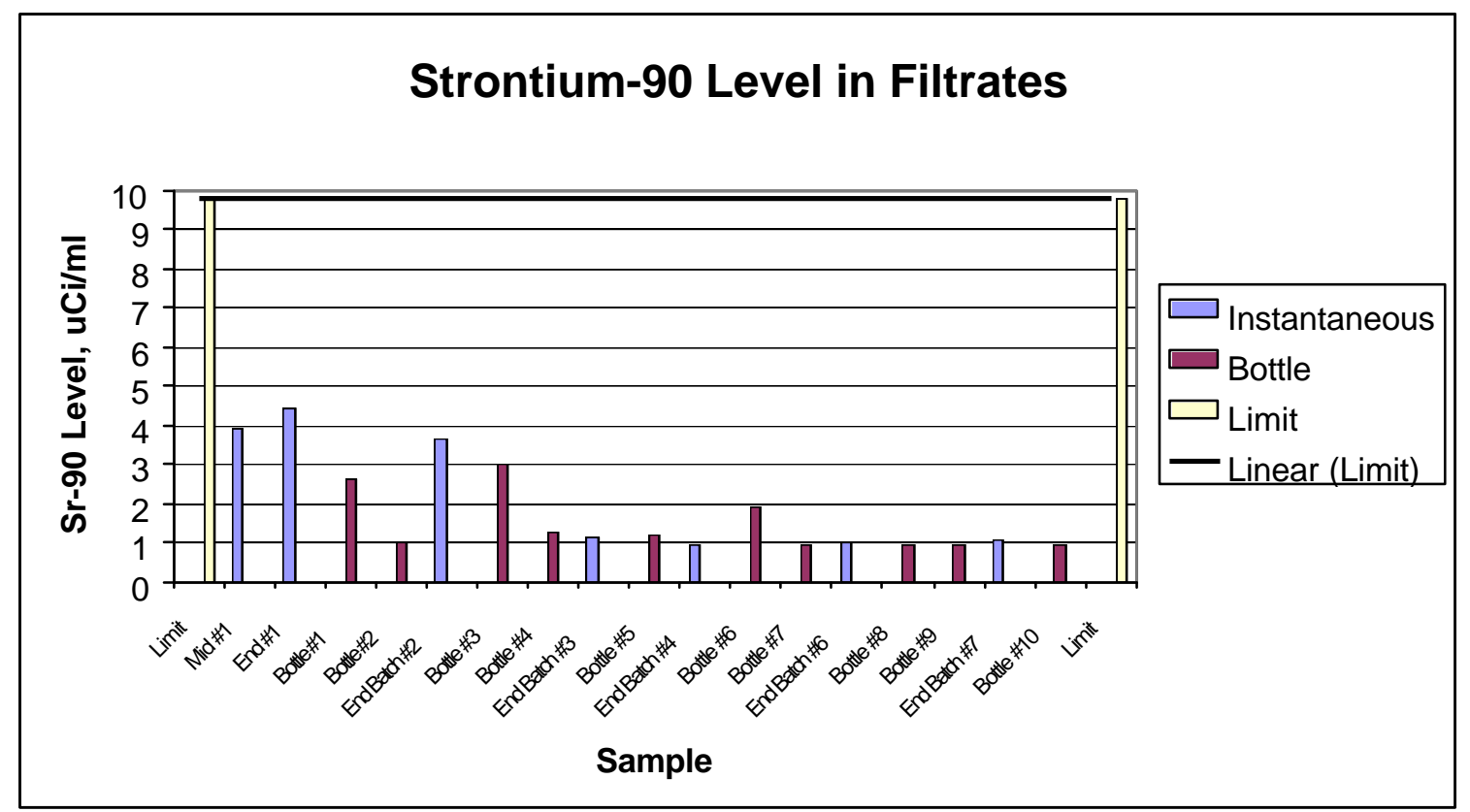

Figure 4 Strontium-90 Level in Filtrates

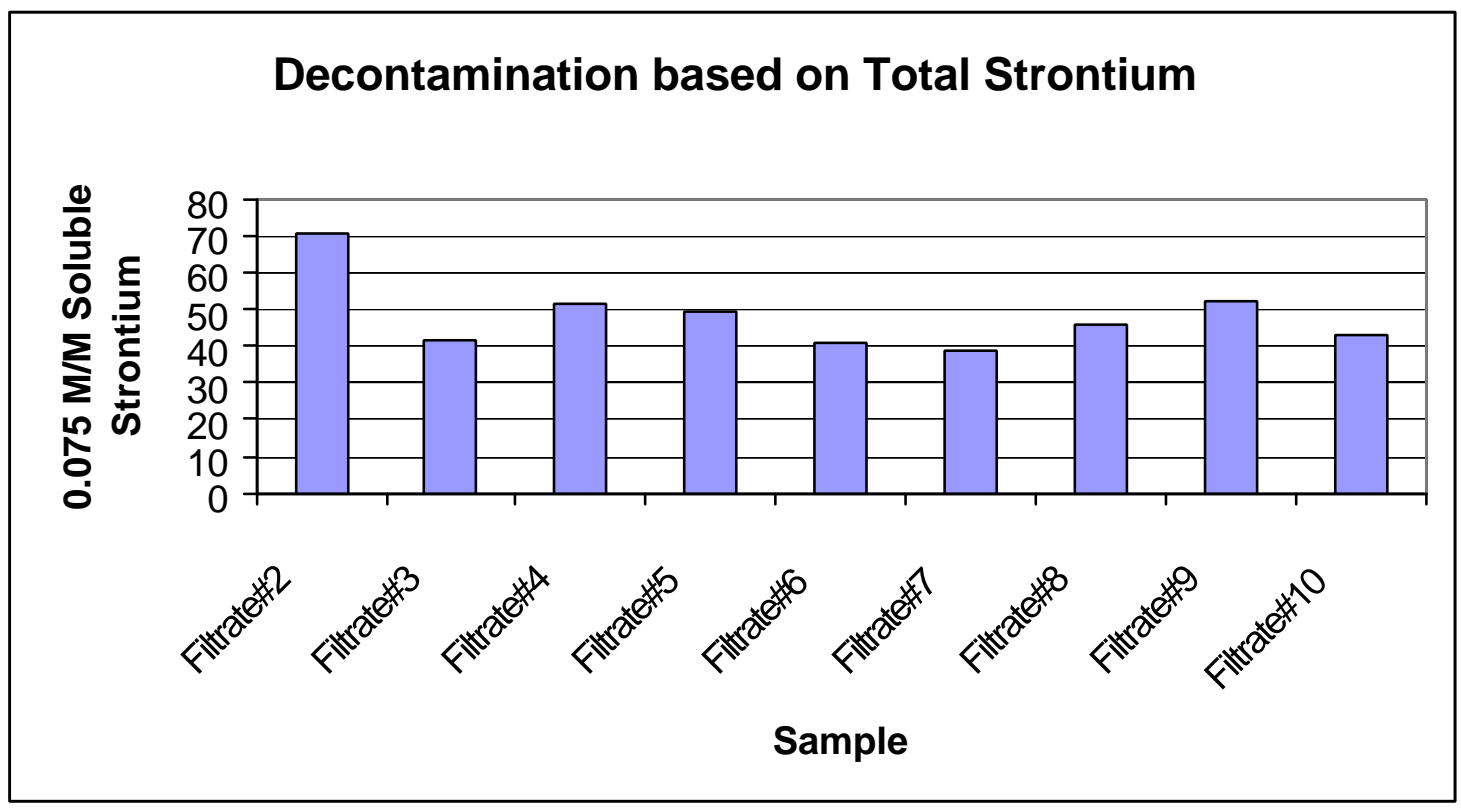

Figure 5 Decontamination based on Total Strontium 
If incoming waste contains negligible total strontium on a molar basis and if the saturation level of soluble strontium in the liquid is known, then decontamination can be expressed by the equation below for perfect isotopic dilution.

DF based on total Strontium $=($ Ret + Sol $) /($ Sol $*$ MDil $)$

where Sol $=($ sample volume $+1 \mathrm{M} \mathrm{SrNO} 3$ added volume $) *$ (final total Sr concentration measured in filtrate), and

Ret $=\mathrm{Sr}$ retained in precipitate, which is $((1$ Molar $* 1 \mathrm{M}$ SrNO3 added volume $)-$ Sol $)$, and MDil is the mass dilution ratio.

\subsubsection{Decontamination - Transuranics}

Figure 6 shows the activities of five transuranic species that were measured. It shows their relative contribution to the total as well. All filtrate product bottles were below the limit of $0.109 \mu \mathrm{Ci} / \mathrm{ml}$ except for filtrate \#8, which appears to have excess curium-244 contamination. The curium was an artifact of the work and is not present to significant levels in 241-AN-102 waste. Removal of the curium contamination from the total activity would show that the product was well below the limit in all cases. The Large $\mathrm{C}$ campaign thus demonstrated robust and ample removal of transuranics from the feed.

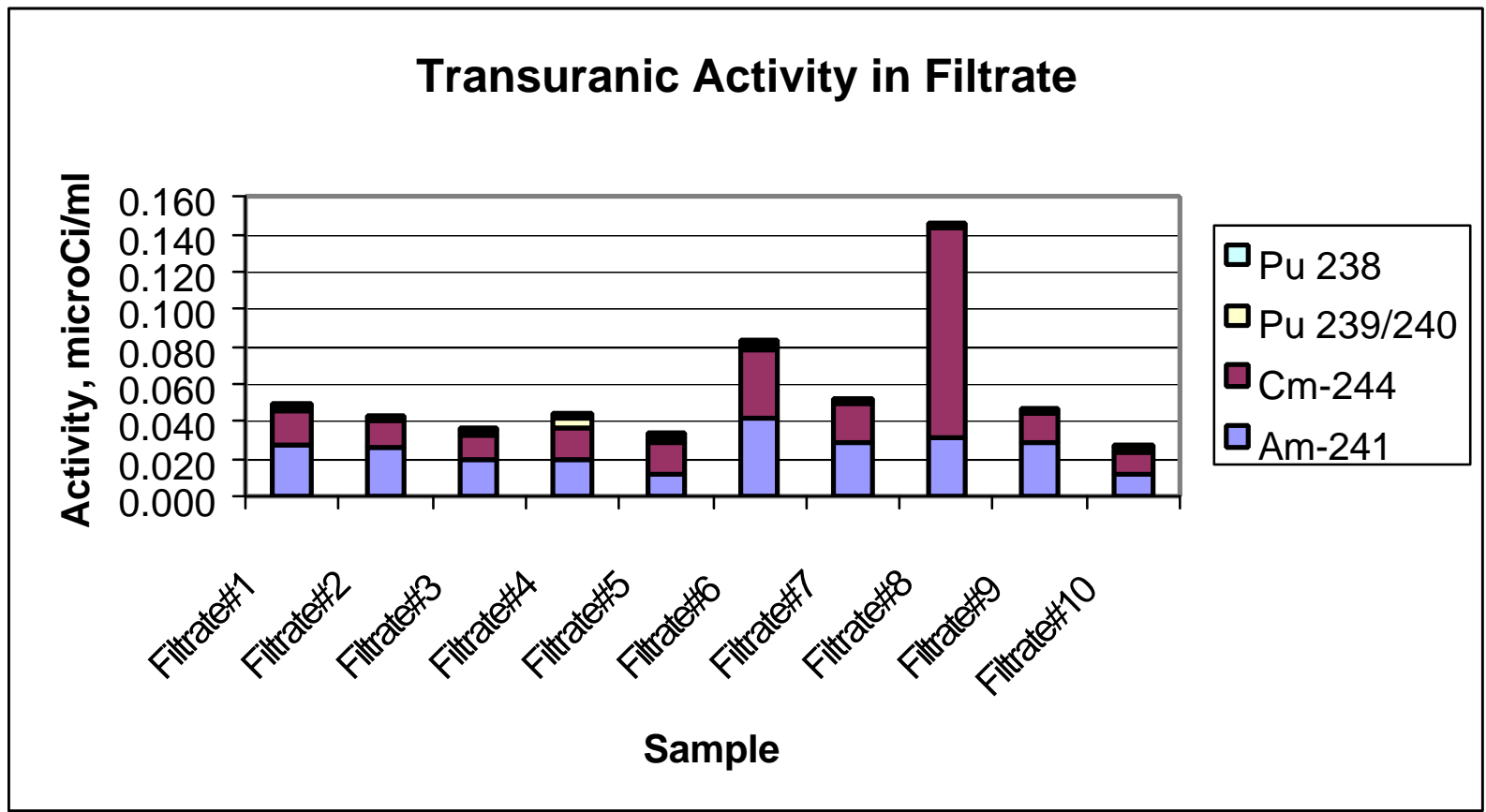

Figure 6 Transuranic Activity in Large C (AN102) Filtrates 
Decontamination factor based on $6 \mathrm{M}$ sodium feed is provided in Table 8. "Filtrate" samples are from the 1 or 2-liter composite collection bottles after each had been filled during the Large $\mathrm{C}$ filtration campaign. Feed activity levels used in the calculations were as found by Hay. ${ }^{12}$ Removal of curium contamination was not calculated because of uncertainties in levels of that element in the input samples. The table shows a simple average and standard deviation for the ten decontaminations with equal weighting, then a volume-based weighted average is shown at the bottom. The volume weighted average was calculated by multiplying each filtrate bottle by its final volume, summing all ten, and dividing by a total product volume of 16.6 liters of filtrate product (wash solutions are excluded).

\section{Table 8 Decontamination Factor for Transuranics in Large C Filtrate Samples}

\begin{tabular}{|l|c|c|}
\hline & Am-241 & Pu 239/240 \\
\hline Filtrate\#1 & 4.4 & 5.5 \\
\hline Filtrate\#2 & 4.7 & 12.4 \\
\hline Filtrate\#3 & 6.3 & 7.2 \\
\hline Filtrate\#4 & 6.0 & 3.3 \\
\hline Filtrate\#5 & 10.1 & 6.4 \\
\hline Filtrate\#6 & 2.9 & 5.2 \\
\hline Filtrate\#7 & 4.2 & 10.1 \\
\hline Filtrate\#8 & 3.8 & 10.7 \\
\hline Filtrate\#9 & 4.2 & 11.3 \\
\hline Filtrate\#10 & 10.0 & 8.2 \\
\hline Average & 5.7 & 8.0 \\
\hline Std. Dev. & 2.5 & 3.0 \\
\hline $\begin{array}{l}\text { Volume } \\
\text { Weighted } \\
\text { Average }\end{array}$ & 5.7 & 8.2 \\
\hline
\end{tabular}

\subsubsection{Decontamination - Technetium-99}

Technetium is clearly not removed from the waste by this precipitation process. This is a disappointment since technetium is a congener of manganese and might thus be expected to precipitate with it, forming a mixed oxide. Figure 7 shows technetium-99 from available batch (instantaneous) and filtrate (2-liter bottle composite) samples. It was measured by mass spectroscopy, which has been found to be more reliable than counting methods for this sample matrix. The technetium-99 level is consistent over these samples and its average value compares well with that of the feed. Hay reported $6.28 \mathrm{mg} / \mathrm{liter}$ $+/-1.4 \%$ at $6.42 \mathrm{M}$ sodium. At $6 \mathrm{M}$ sodium that would be $5.85 \mathrm{mg} / \mathrm{liter}$ which compares well with the average and standard deviation given on the figure. 


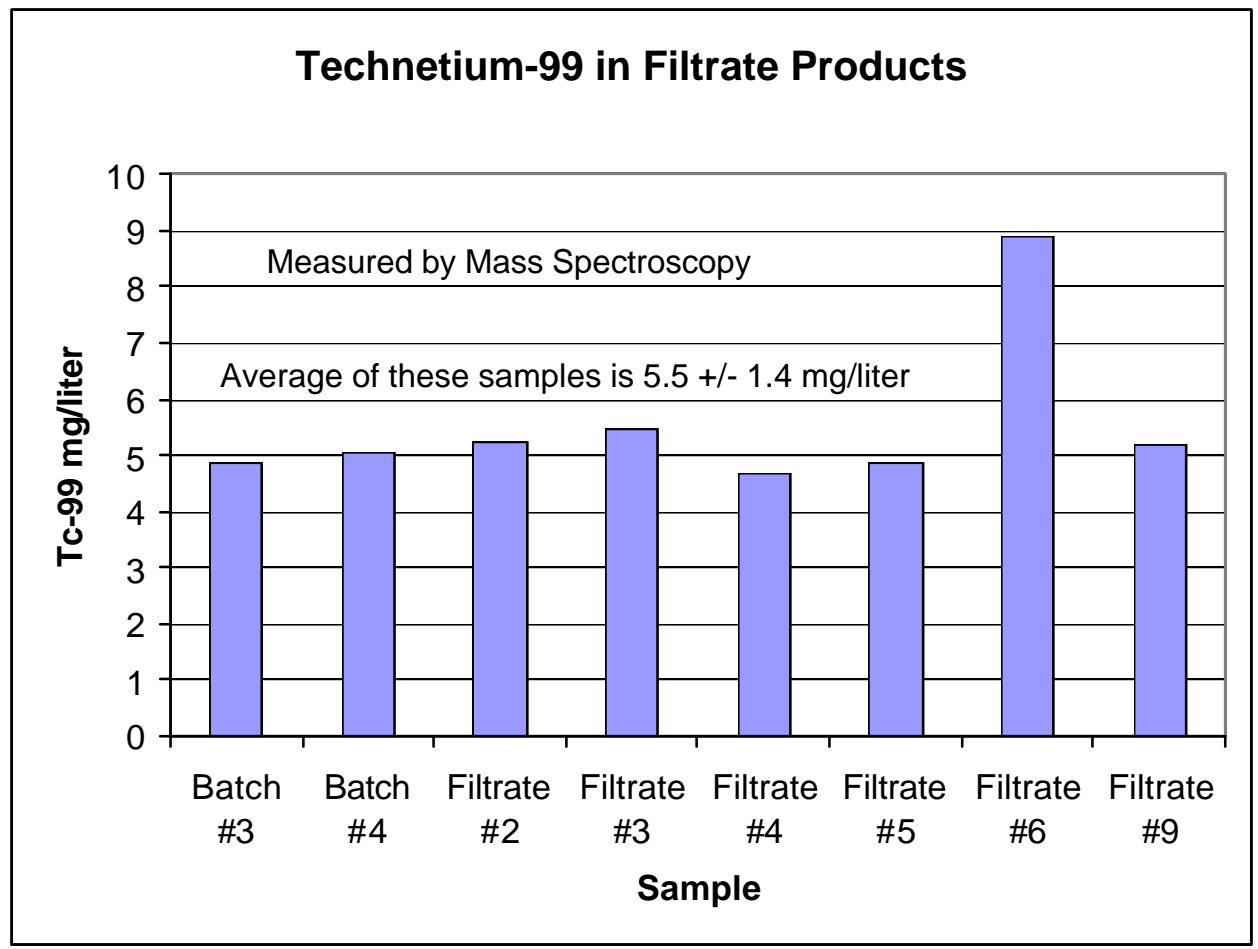

Figure 7 Technetium Levels in Product Filtrate Samples

This finding is confirmed by calculated quantities of the Tc- 99 entering and leaving the precipitation process. Input into the experiment was $16.4 \mathrm{~L}$ of material at an average 6.06 M Na containing $5.93 \mathrm{mg} / \mathrm{L} \mathrm{Tc}-99$ for a total of $97.2 \mathrm{mg} \mathrm{Tc}-99$. Leaving the experiment for ion exchange was nearly $18.9 \mathrm{~L}$ composited product (16.6 L filtrate $+2.3 \mathrm{~L}$ wash) containing $4.31 \mathrm{mg} / \mathrm{L} \mathrm{Tc}-99$ (King ${ }^{19}$ ) for a total of $81.5 \mathrm{mg} \mathrm{Tc}-99$. An additional 14.4 $\mathrm{mg}$ Tc-99 can be accounted for through purged CUF concentrate and samples (approximately $3.2 \mathrm{~L}$ ) containing an estimated $14 \mathrm{wt} \%$ solids and assuming a dilution factor of 1.13 from $5.93 \mathrm{mg} / \mathrm{L}$ due to addition of precipitating agents. The total Tc-99 effluent from the CUF was estimated to be $95.9 \mathrm{mg}$ leading to a Tc-99 balance closed to within $1.5 \%$, well within the $5 \%$ estimated analytical error. An alternate verification is an unchanged concentration ratio of $\mathrm{K}$ and $\mathrm{Tc}$, two species not removed in the precipitation process, in the tank waste and the ion exchange feed material. Hay's feed characterization data ${ }^{20}$ yields a K/Tc ratio of $555(0.0352 \mathrm{M} \mathrm{K} / 0.0000634 \mathrm{M} \mathrm{Tc})$ and King's data gives a ratio of $574(0.025 \mathrm{M} \mathrm{K} / 0.0000435 \mathrm{M} \mathrm{Tc})$. The $3.4 \%$ difference in the calculated ratio is again within the $5 \%$ estimated analytical error.

\subsubsection{Components Showing Little Removal}

The strontium-permanganate process leaves many components in the filtrate product with insignificant removal efficiency. Components like aluminum and sulfate are desired to stay in the filtrate because they are better handled in the Low Level Waste melter as 
WSRC-TR-2000-00506

SRT-RPP-2001-00006

BNF-003-98-0317

opposed to the much smaller High Level Waste melter. It would be a benefit if other components like cesium and technetium were removed during precipitation, but they are handled by ion exchange columns just downstream of the precipitation process.

Table 9 shows splits of stable elements whose concentrations were measured in both the concentrate and filtrate during the campaign. Concentration ratios near unity show elements that are not separated very well. Strontium and manganese levels are artificially high because of the addition of these elements for precipitation.

It is interesting to note that barium, copper, iron, lead, tin, zirconium, and cadmium to some extent were separated more efficiently in the first batch than in the following six batches. This is despite the lower addition of strontium $(0.02 \mathrm{M}$ versus $0.075 \mathrm{M}$ after mixing) and lower permanganate level ( 0.03 versus $0.05 \mathrm{M}$ addition) for the first batch. Since this batch had added calcium these elemental levels provide evidence of the efficacy of calcium to increase removal of elements targeted by the process. It is fortunate that Batch 1 had two sets of samples so that this effect could be verified.

Table 9 Table of Slurry-Based Decontamination Factors for Metallic Elements

\begin{tabular}{|c|c|c|c|c|c|c|c|}
\hline Element & $\begin{array}{c}\text { BATCH } \\
\text { 1-Mid }\end{array}$ & $\begin{array}{c}\text { BATCH } \\
1-\text { End }\end{array}$ & $\begin{array}{c}\text { BATCH } \\
2\end{array}$ & $\begin{array}{c}\text { BATCH } \\
3\end{array}$ & $\begin{array}{c}\text { BATCH } \\
4\end{array}$ & $\begin{array}{c}\text { BATCH } \\
5\end{array}$ & $\begin{array}{c}\text { BATCH } \\
7\end{array}$ \\
\hline $\mathrm{Al}$ & 1.0 & 1.1 & 0.3 & 0.7 & 1.2 & 0.6 & 0.1 \\
\hline$B$ & & & 1.2 & 0.9 & 1.1 & $\overline{1.1}$ & 1.1 \\
\hline $\mathrm{Ba}$ & 21.6 & 25.6 & 7.6 & 0.3 & 5.5 & 4.8 & 9.6 \\
\hline $\mathrm{Ca}$ & 2.4 & 2.5 & 2.6 & 1.5 & 1.9 & 1.6 & 1.8 \\
\hline $\mathrm{Cd}$ & 1.4 & 1.6 & 1.0 & 0.9 & 0.8 & 0.8 & 0.8 \\
\hline $\mathrm{Cr}$ & 2.0 & 2.2 & 1.8 & 1.3 & 1.1 & 1.5 & 1.9 \\
\hline $\mathrm{Cu}$ & 2.6 & 3.0 & 0.7 & 0.4 & 0.5 & 0.5 & 0.5 \\
\hline $\mathrm{Fe}$ & 48.0 & 80.1 & 3.7 & 2.5 & 10.2 & 7.6 & 5.1 \\
\hline $\mathrm{Mg}$ & 5.0 & 5.0 & 25.4 & 2.6 & 49.8 & 2.5 & 1.4 \\
\hline $\mathrm{Mn}$ & 3579.1 & 841.5 & 384.8 & 247.6 & 345.3 & 705.5 & 285.1 \\
\hline Mo & 1.9 & 1.8 & 0.9 & 0.8 & 0.7 & 0.7 & 0.7 \\
\hline $\mathrm{Na}$ & 1.0 & 1.1 & 1.0 & 1.0 & 0.9 & 0.9 & 0.7 \\
\hline $\mathrm{Ni}$ & 1.2 & 1.4 & 1.3 & 0.9 & 0.9 & 1.0 & 0.9 \\
\hline P & 1.2 & 1.2 & 1.1 & 0.9 & 0.8 & 0.9 & 0.8 \\
\hline $\mathrm{Pb}$ & 4.1 & 5.7 & 1.9 & 0.7 & 1.1 & 1.1 & 1.2 \\
\hline Sn & 4.6 & 4.2 & 0.2 & 0.4 & 0.6 & 0.4 & 0.2 \\
\hline $\mathrm{Sr}$ & 35.0 & 34.8 & 108.8 & 8.0 & 38.9 & 36.2 & 49.5 \\
\hline Tc & bd & bd & 0.5 & 0.5 & bd & bd & bd \\
\hline $\mathrm{Zn}$ & 3.3 & 2.4 & 3.0 & 0.6 & 4.1 & 3.8 & 6.2 \\
\hline $\mathrm{Zr}$ & 15.0 & 18.6 & 0.0 & 0.2 & 0.0 & 0.0 & 0.1 \\
\hline
\end{tabular}

$\mathrm{bd}=$ below detection 
Table 9 data from Batches 2 to 7 were averaged because they all used the same precipitation recipe. Results are tabulated in Table 10 for the leftmost data column under "This Work". The results of other works are also shown for comparison where data are available. The other works referenced are as follows:

241-AN-102 Small C - Reference 4

Simulant 241-AN-107 Cold CUF - Reference 2

241-AN-107 PNNL - Reference 3

These works were compared partly to draw general conclusions on precipitation process performance across the variation represented by tank 241-AN-102 and tank 241-AN-107 materials. Elements not removed in either case are, for example, easily modeled in the process flowsheet without further effort.

Table 10 Elemental Split across the Filter - ICP-ES Data, Several Works

\begin{tabular}{|c|c|c|c|c|c|}
\hline Sample: & \begin{tabular}{|l} 
AN-102 \\
(This \\
Work)
\end{tabular} & & \begin{tabular}{|l} 
AN-102 \\
Small C \\
Ref. 4
\end{tabular} & \begin{tabular}{|l|} 
Sim. AN-107 \\
Cold CUF \\
Ref. 2
\end{tabular} & $\begin{array}{l}\text { AN-107 } \\
\text { PNNL } \\
\text { Ref. } 3\end{array}$ \\
\hline & & & & & \\
\hline & Average & St Dev & & & \\
\hline$|\mathrm{Al}|$ & 0.6 & 0.37 & 0.9 & 0.9 & 1.1 \\
\hline $\mathrm{B}$ & 1.1 & 0.09 & 1.0 & & \\
\hline $\mathrm{Ba}$ & 5.5 & 3.11 & & & \\
\hline $\mathrm{Ca}$ & 1.9 & 0.40 & 1.5 & 2.4 & 1.6 \\
\hline $\mathrm{Cd}$ & 0.9 & 0.09 & 1.0 & & 1.0 \\
\hline $\mathrm{Cr}$ & 1.5 & 0.30 & 1.4 & & 2.0 \\
\hline $\mathrm{Cu}$ & 0.5 & 0.12 & 1.0 & $>10$ & \\
\hline $\mathrm{Fe}$ & 5.8 & 2.76 & 8.7 & 5.3 & 100 \\
\hline $\mathrm{Mg}$ & 16.3 & 19.00 & & & \\
\hline Mo & 0.8 & 0.09 & 0.9 & & \\
\hline $\mathrm{Na}$ & 0.9 & 0.10 & 1 & 1.0 & 1.0 \\
\hline $\mathrm{Ni}$ & 1.0 & 0.16 & 1 & 1.0 & 1.0 \\
\hline$P$ & 0.9 & 0.11 & 0.9 & 1.1 & 1.0 \\
\hline $\mathrm{Pb}$ & 1.2 & 0.41 & 1.4 & & 2.5 \\
\hline Sn & 0.4 & 0.16 & 0.4 & & \\
\hline $\mathrm{Sr}$ & 48.3 & 33.21 & 39.3 & 91 & 120 \\
\hline Tc & 0.5 & & & & \\
\hline $\mathrm{Zn}$ & 3.5 & 1.81 & 2.4 & 1.3 & \\
\hline $\mathrm{Zr}$ & 0.1 & 0.05 & 0.3 & & \\
\hline & & & & & \\
\hline $\begin{array}{l}\text { Added } \\
\text { Mn, M }\end{array}$ & 0.05 & & 0.044 & 0.04 & 0.05 \\
\hline \begin{tabular}{|l|} 
Added \\
Sr, M
\end{tabular} & 0.075 & & 0.066 & 0.075 & 0.075 \\
\hline
\end{tabular}


Aluminum, boron, cadmium, molybdenum, sodium, nickel, and phosphorus are clearly not removed by this process and remain in the filtrate whether the feed is from tank 241-AN-102 or from tank 241-AN-107. Approximately half of calcium, chromium, lead, zinc are removed. The process always has a strong interaction with iron and removes at least $80 \%$ of it.

Decontamination of strontium based on elemental totals compares well with decontaminations based on Sr-90 activity. The data from this set of samples thus supports the data shown in the Strontium Decontamination section which used total and Sr-90 data from other sample sets. This equality indicates that isotopic mixing in the process is complete. While this affirms the goal of activity reduction by isotopic dilution it also gives some credibility to the use of nonradioactive simulants to report a strontium decontamination where only data from total strontium measurements is available.

\subsubsection{Analyses of Final Filtrate Products}

All $6 \mathrm{M}$ sodium and slurry wash filtrates were composited for the sake of delivery to the cesium ion exchange process. Table 11 shows how the composite greatly exceeds the decontamination for both strontium-90 and transuranics. An analysis of this grand composite is shown in Appendix C. The material composition is pretty much as expected, and decontamination numbers from this data set show the material met decontamination requirements.

Table 11 Radiochemical Data for Final Product Composite

\begin{tabular}{|l|c|r|r|}
\hline ADS\# 145153 & & & \\
\hline Radiochem & $\begin{array}{c}\text { Dilution- } \\
\text { Corrected }\end{array}$ & & \\
\hline & dpm $/ \mathrm{mL}$ & $\mu \mathrm{Ci} / \mathrm{ml}$ & Limit for $4.8 \mathrm{M} \mathrm{Na}+$ \\
\hline Sr-90 & $2.03 \mathrm{E}+06$ & 0.9144 & $6.7 \mu \mathrm{Ci} / \mathrm{ml}$ \\
\hline & & & \\
\hline & $\mathrm{dpm} / \mathrm{mL}$ & $\eta \mathrm{Ci} / \mathrm{ml}$ & \\
\hline $\mathrm{Pu}-238$ & $2.06 \mathrm{E}+03$ & 0.9 & \\
\hline $\mathrm{Pu}-239-240$ & $1.64 \mathrm{E}+03$ & 0.7 & \\
\hline $\mathrm{Am}-241$ & $2.31 \mathrm{E}+04$ & 10.4 & Transuranic Total must be \\
\hline $\mathrm{Cm}-244$ & $2.51 \mathrm{E}+04$ & 11.3 & Less than $87.6 \eta \mathrm{Ci} / \mathrm{ml}$ \\
\hline & & & \\
\hline Cs-137 & $3.34 \mathrm{E}+08$ & 150.5 & \\
& & $\mu \mathrm{Ci} / \mathrm{ml}$ & \\
\hline Cs-137 $(\mu \mathrm{Ci} / \mathrm{ml})$ & 150.52 & & \\
\hline
\end{tabular}




\subsubsection{Chemical Analysis of Slurry Washing}

BNF-003-98-0317

The slurry concentrate in the CUF at the end of Batch \#7 filtration was washed with inhibited water $(0.01 \mathrm{M} \mathrm{NaOH})$. Four $600-\mathrm{ml}$ portions of washwater were used to generate four $600-\mathrm{ml}$ samples of spent washwater. Slurry being washed was left in the rig between each $600-\mathrm{ml}$ wash and was only removed at the end. Data from the four washwater analyses are presented below to show impacts of the washing sequence on chemistry and radioactive elements.

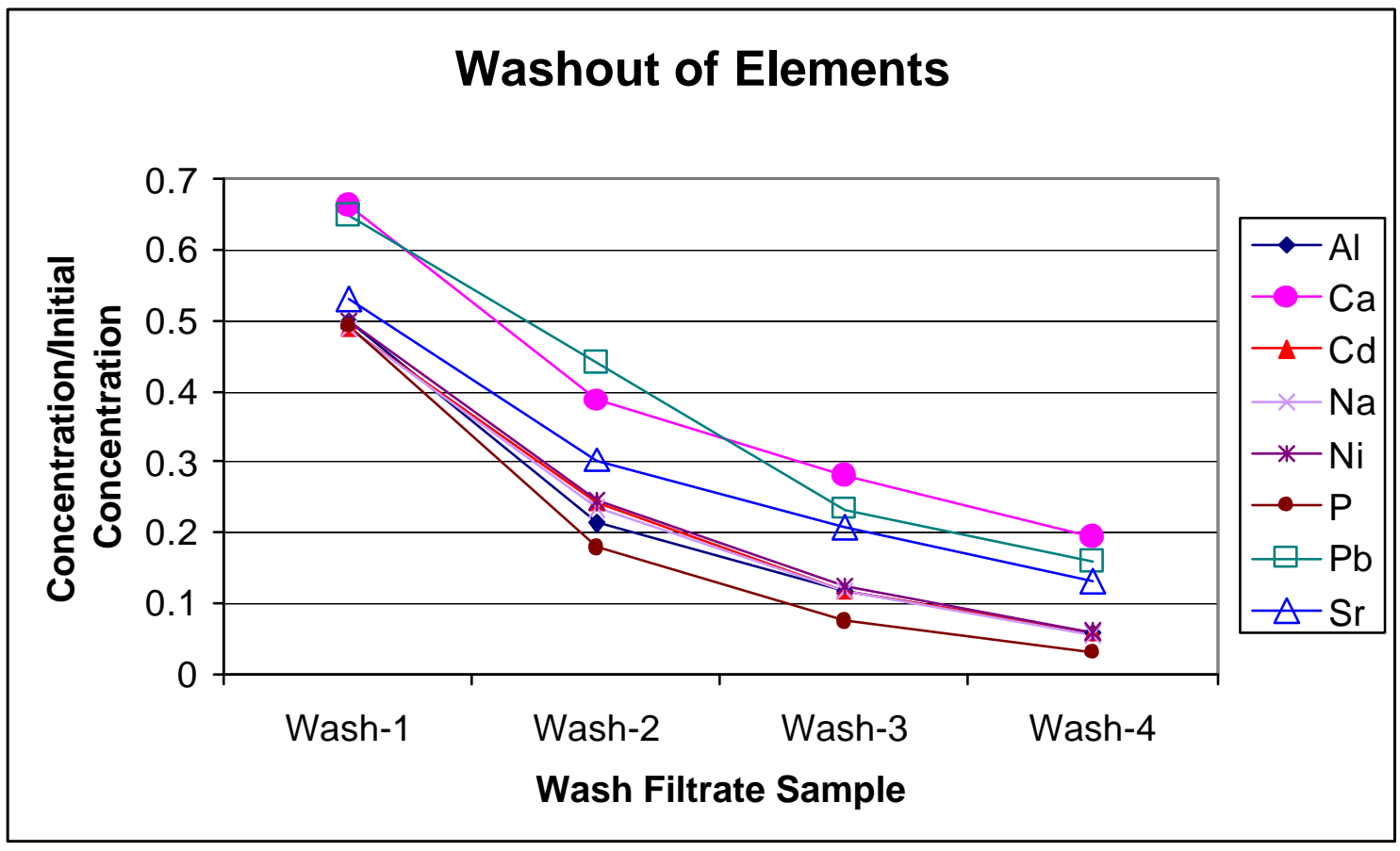

Figure 8 Washout of Elements

Elements that could be detected by ICP-ES in all four of the 600-ml "Wash-1" to "Wash-4" samples are shown in Figure 8. Two types of washout behaviors are clearly shown. These are separated in the figure by use of large versus smaller plot symbols.

Sodium, nickel, phosphorus, and cadmium appear to wash out by a dilution effect only, as if they have insignificant association with the solids in the slurry. These are shown with small plot symbols in Figure 8. The filtration rig inventory volume is estimated to be $800 \mathrm{ml}$, but the $600 \mathrm{ml}$ of washwater passed through it for each "Wash-\#" sample appears to reduce soluble concentration by half. This higher efficiency would be expected because the washwater was pumped in semi-continuously rather than all at once - the rig would not have been able to hold all $600 \mathrm{ml}$ in a one-time addition. The permanganate process in all previous work did not remove these elements. 
Calcium, strontium, and lead washed out with apparent bleed from the slurry solids. These are plotted with the larger symbols. The curves are higher than those of purely soluble elements, indicating that they are bleeding from the solids to some extent. Strontium is an important part of the slurry and would have this expected behavior. Calcium, as well, associates in some way with the manganese oxide-hydroxide solids in the slurry and thus washes out slowly. Lead has a removal factor of slightly above unity and is removed by the caustic wash solution as shown.

Manganese was below detection in the Wash-3 and -4 samples and was only $10 \mathrm{mg} / \mathrm{l}$ and $1.6 \mathrm{mg} / \mathrm{l}$ in the Wash-1 and Wash-2 samples, respectively. The form of manganese in the slurry was thus insoluble with respect to the washing operation. It did not bleed out significantly.

Figure 9 shows that sodium and Cs-137 wash out as totally-soluble components. These are plotted with heavy lines and both follow the same trend of halved concentration with each 600-ml wash. Americium-241, the most prevalent source of transuranic activity, is retained by the slurry solids and shows no significant bleed.

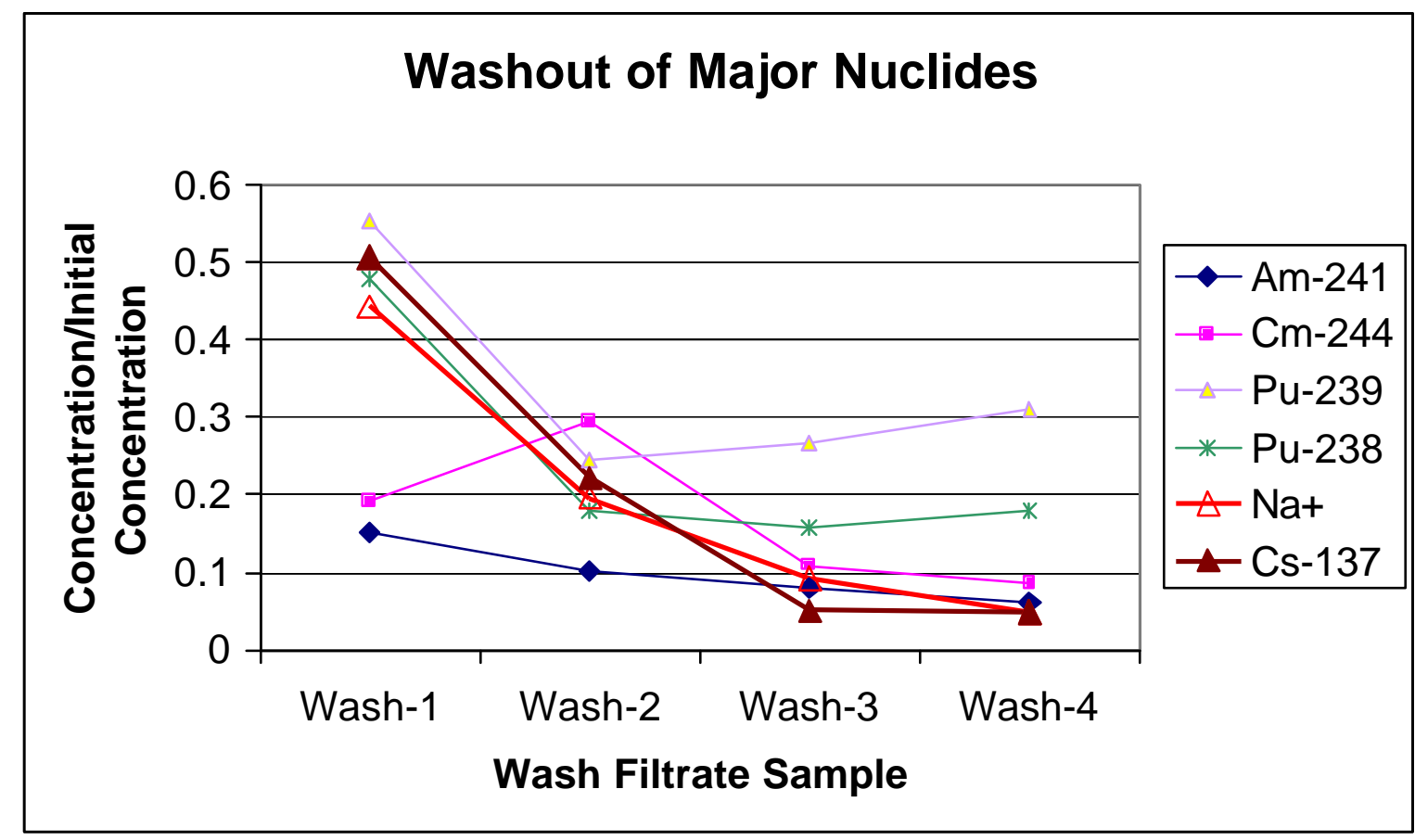

Figure 9 Washout of Major Nuclides 
WSRC-TR-2000-00506

SRT-RPP-2001-00006

BNF-003-98-0317

Plutonium behavior initially follows the trend of diluted soluble elements, but then seems to begin to wash out of the solids in the latter two washes. This is seen by its departure from the normal downward trend in Washes 3 and 4. Sodium and cesium follow a downward trend where concentrations are roughly halved with each new wash. The lower ionic strength of the slurry might have promoted this bleeding for plutonium. It is fortunate that plutonium contributes no more than about $10 \%$ of the total transuranic activity; the permanganate process thus retains the most important element (Am-241) during washing. Curium-244 behavior is uncertain at the first data point, but follows the soluble components beyond the first data point (average of two measurements). It shows little evidence of accelerated bleeding during slurry washing. This curium is not a normal part of complexant waste and contributes an insignificant amount of transuranic activity. Curium-244 has been found in higher levels alone in the sample used here due to inadvertent contamination of the 241-AN-102 sample within the SRTC hot cells.

Table 12 shows the absolute values of the product filtrate used to plot the two preceding dimensionless graphs. In all cases the measured values from filtrate sample bottles \#8, $\# 9$, and \#10 were averaged and the standard deviation of each initial value is presented as a percentage of the average value. The averaging was done so that an error could be calculated from experimental values. Bottles 8 to 10 were used because these were the last filtrate bottles, when the process using concentrated slurry would be running closest to steady state.

Table 12 Average Initial Concentration of Filtrate Product, Last Three Bottles

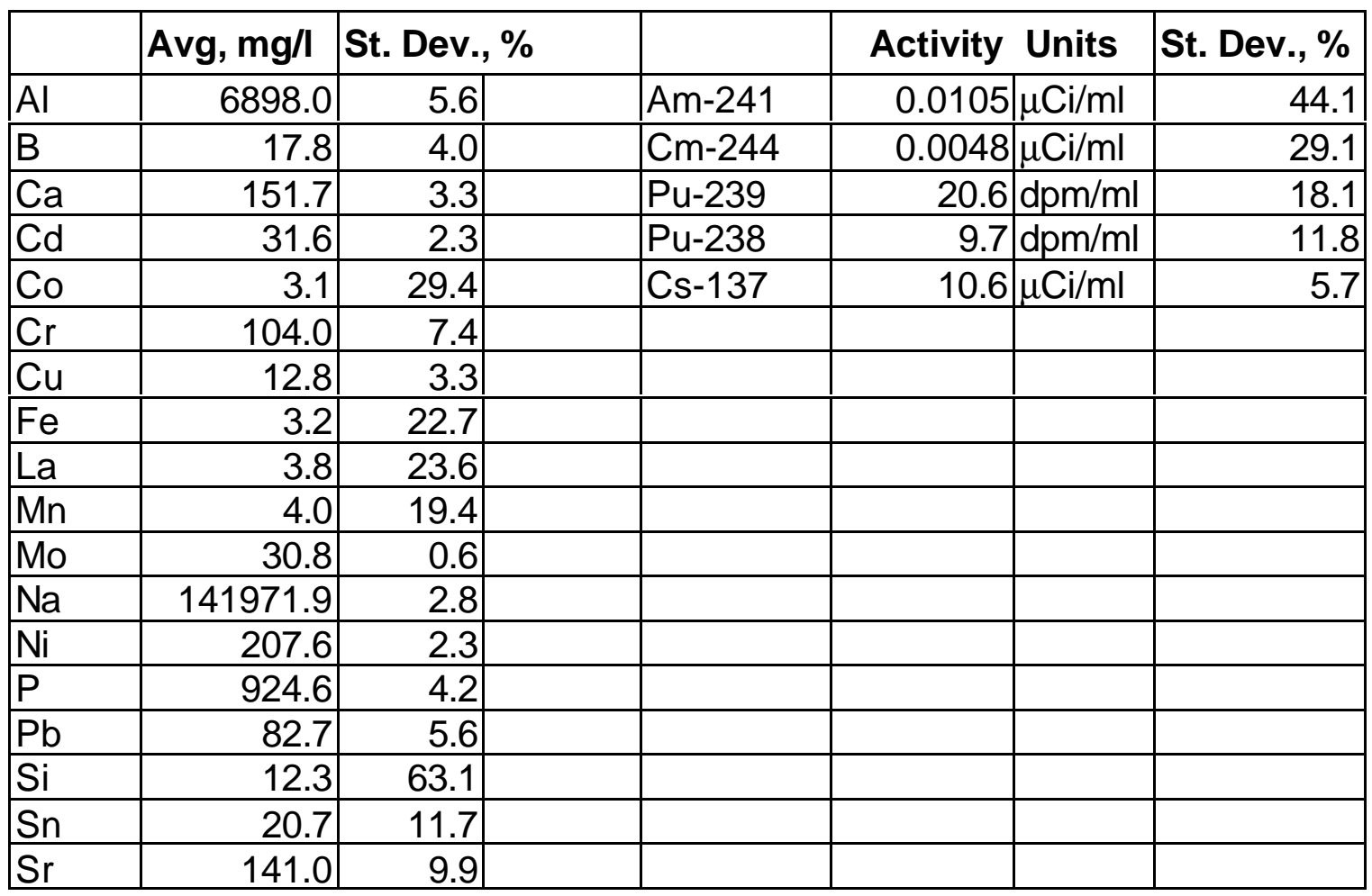




\subsubsection{Filter Cleaning - Flush Solution Compositions}

This section presents compositions of the flush solutions after they were used to clean the rig and crossflow filter. The cleaning protocol used water and $1 \mathrm{M}$ nitric acid.

After the precipitate filtration/washing series the rig was drained of slurry. Several difficulties were encountered. The washed slurry product did not drain by gravity when the drain valve was opened. The valve was closed and it was then found that the slurry pump was hard to start. Pressure applied to the air motor was cycled up and down quickly and the pump was found to start when the air pressure was spiked to $110 \mathrm{psig}$, the maximum available pressure. $300 \mathrm{ml}$ of slurry (less than half of the expected rig volume) was drained with the pump operating at slow speed. That volume was stored in its own sample bottle. This volume was replaced with $300 \mathrm{ml}$ of inhibited water. It was circulated at $3.5 \mathrm{gpm}$ (13.25 liters/min) for 10 minutes. This water drained slowly and appeared to contain a lot of slurry solids when it was drained. Only $300 \mathrm{ml}$ drained again. This was replaced with $300 \mathrm{ml}$ of inhibited water and the process repeated. This time $600 \mathrm{ml}$ of inventory was drained and the rig was thus considered ready for a cleaning operation. Work up to this point was considered to be slurry removal.

The rig was charged with $700 \mathrm{ml}$ of inhibited water. It was circulated for 30 minutes at $4 \mathrm{gpm}$ (15 liters/min). There was no backpulsing. This liquid was drained and a sample named "Waterflush" was taken. The liquid was still black, but appeared to have waterlike consistency.

The rig was then flushed with a full inventory of $1 \mathrm{M}$ nitric acid for a total of one hour. The filter was backpulsed and fluxes were measured. This acid flush still contained visible black solids. The liquid was then drained and stored as Sample "1 M Nitric" flush. The rig was charged with an inventory of deionized water. This was left to sit overnight. This flush water wash was circulated for an hour the next day, and sampled. This was called the "Final Water" sample.

Figure 10 shows elemental compositions found after the named flush samples were acid digested and diluted to one thirtieth of their as-withdrawn concentration. The figure shows that the nitric acid flush had significant effect; acid concentrations of elements were not far below values found in the initial water flush and were significantly higher than those of the water that resided in the rig overnight.

Figure 11 shows that the nitric acid flush again dissolved many of the radioactive elements that were detected. Their level descends more quickly after the use of the acid. The only exception here was Tc-99, which seemed to bleed more uniformly into all three flush samples. The holdup mechanism for Tc-99 is unknown. Both sodium from the Figure 10 and Cs-137 here show a peak during the acid use. To get correct absolute values of activities from Figure 11 it is necessary to use the scale factors in the legend for two of the elements. The value of using them was the ability to note trends for all of the active elements on one figure. 


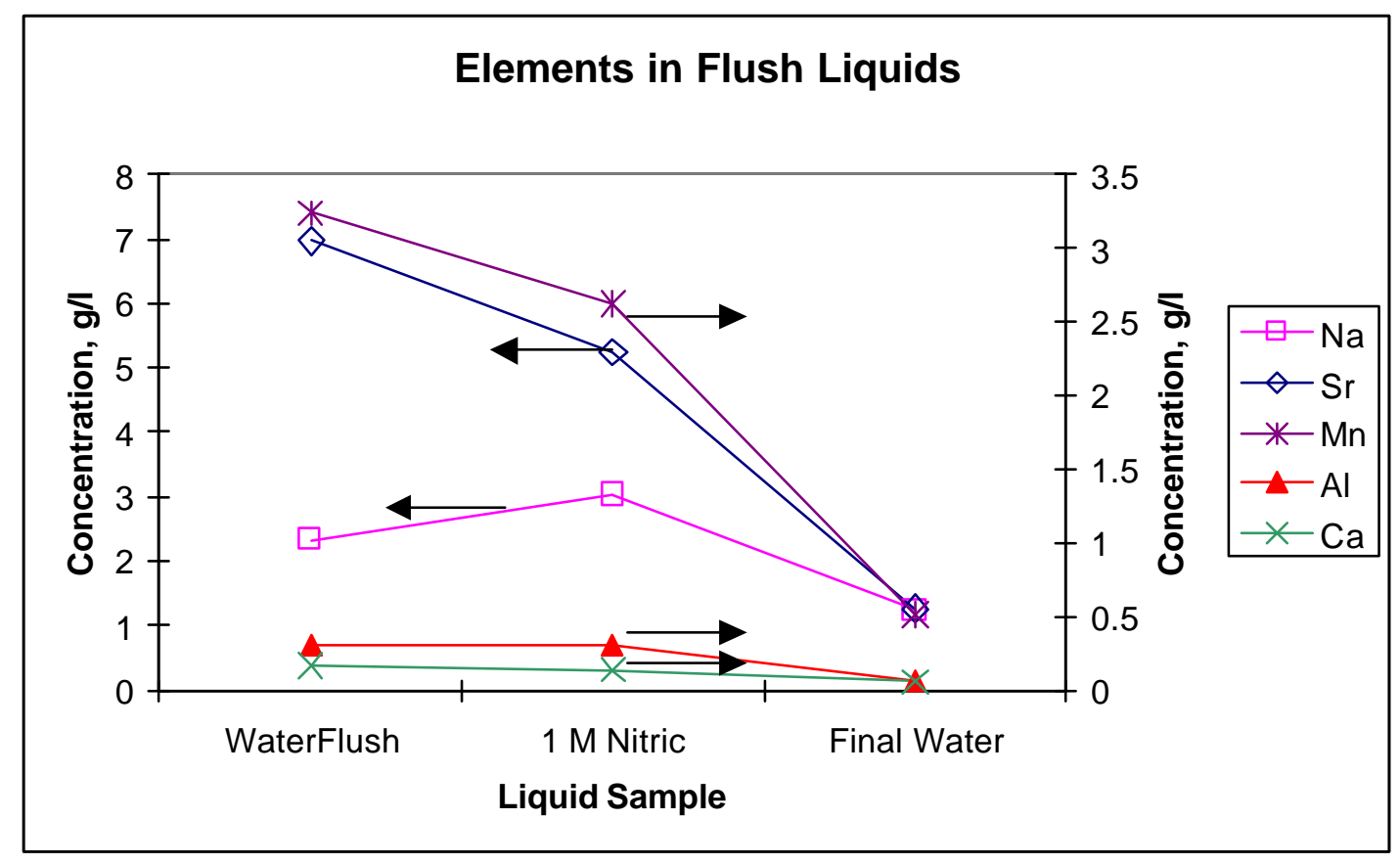

Figure 10 Elements Found in Flush Solutions

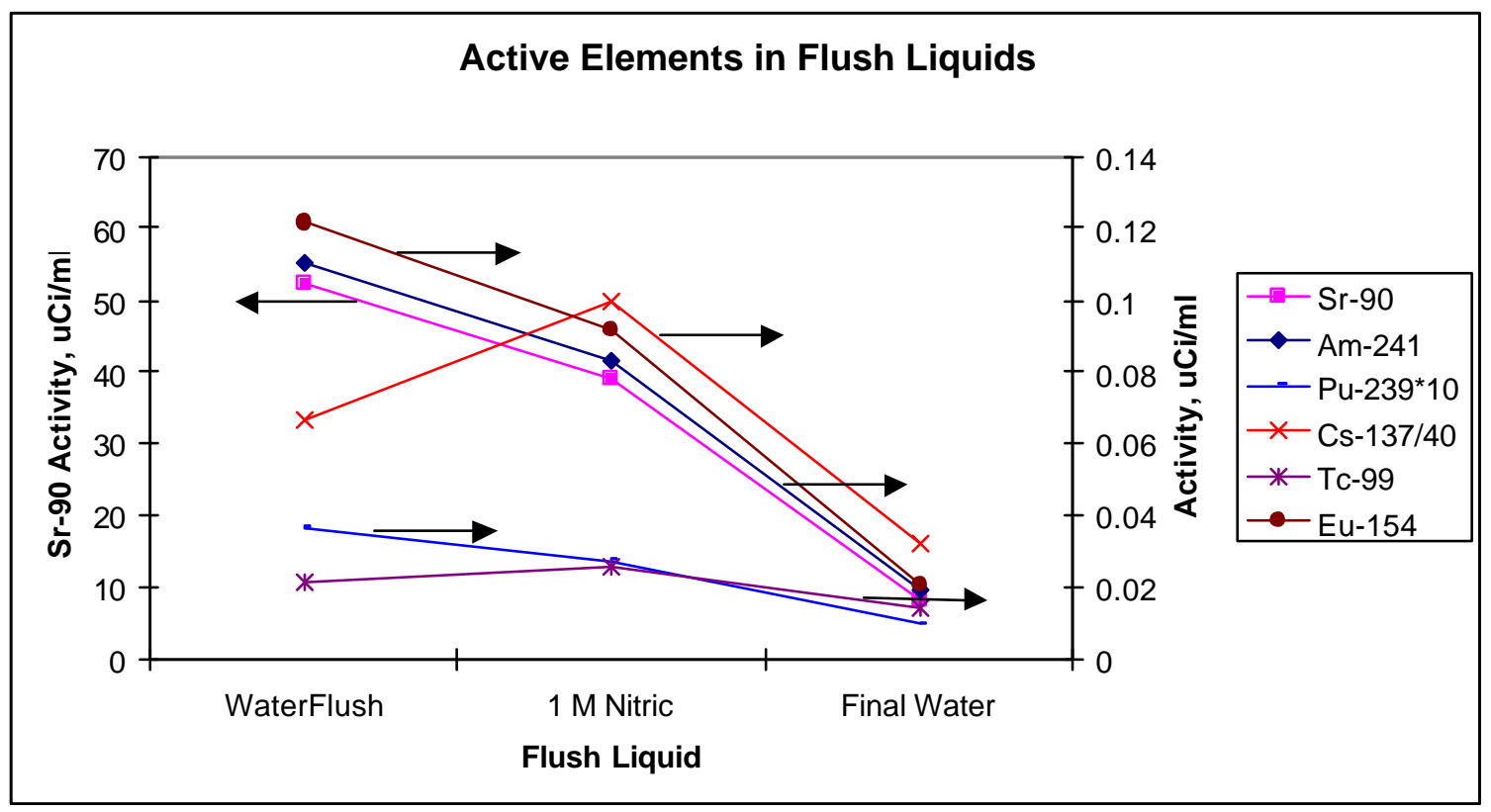

Figure 11 Active Elements in Flush Liquids 
The trends noted above depend on the geometry of the filter loop, the number of deadlegs, tank heels, and internal surface per volume. The relative amount of internal surface is high for the small cells filter rig used here, and this would affect the amount of highly concentrated slurry stuck inside after the system is drained.

\subsubsection{Final Compositions of Major Products of the Campaign}

This campaign produced two major liquids of great significance to the RPP flowsheet - a composite of all filtrate plus washwater, and a washed strontium-manganese slurry. While many samples were taken and the data presented above, the analysis of the final products sent to other unit operations is included in this report for completeness.

The grand composite for the filtrate and spent wash is in Appendix C. The sodium level as measured was $4.82 \mathrm{M}$, addition of wash filtrate being the main reason for the dilution. The Sr-90 activity was over 7 times lower than the limit for this sodium level, and transuranic activity was 4 times below that limit. These great conservatisms for this large campaign show that the process is extremely robust and that good reductions in both strontium nitrate and sodium permanganate reagents can be tolerated for processing 241AN-102 complexant waste. The inclusion of the washwater in the composite provided the benefit of lowering the sodium molarity for the sake of ion exchange - resin may float if the molarity is too high.

The washed slurry analysis in given in Appendix C. It is mainly strontium and manganese-bearing solids in a solution bearing residual sodium.

\subsubsection{Observations on Post Precipitation}

Various researchers have noted that the filtrate from permanganate precipitation appears to drop small amounts of black solid on standing. While no systematic study of this has been published, it was planned to watch the bottles of filtrate product from this campaign for such post-filtration precipitation solids.

In summary, some bottle discoloration, but no solids, was seen with the bottles of high sodium filtrate product. Free solid formation was seen with the lower sodium filtrate from washing. All Filtrate bottles \#1 to \#10 were checked after sitting in the shielded cells for two weeks after they were produced. No solids were seen in the bottles, but some discoloration of the polyethylene that was in contact with the solution in each bottle was observed. The filtrates were clear and straw-colored, while the discoloration was gray-black. Bottles containing filtrate from the first two of four washes formed visible solids within two days of standing. It was noted that the solutions in the bottles were light brown-yellow and clear. No post-filtration precipitation solids were captured or analyzed in this work. 


\subsection{FILTRATION RESULTS}

BNF-003-98-0317

\subsubsection{Filtration Flux Data Summary}

The table below summarizes the average filter fluxes obtained for each batch of precipitated Hanford AN-102 Large C waste, filter conditions and settings, and insoluble solids concentration average and range. The average flux and insoluble solids concentrations were calculated by integral average over the volume of filtrate produced.

Table 13. Summary of CUF Flux Data

\begin{tabular}{|c|c|c|c|c|c|c|c|}
\hline $\begin{array}{c}\text { Batch } \\
\quad \#\end{array}$ & $\begin{array}{l}\text { Precip. } \\
\text { Chem }\end{array}$ & TMP & $\begin{array}{l}\text { Axial } \\
\text { Veloc. }\end{array}$ & Avg. Flux & $\begin{array}{l}\text { Measurement } \\
\text { Time (min) }\end{array}$ & $\begin{array}{l}\text { Avg. IS } \\
(w t \%)\end{array}$ & $\begin{array}{c}\text { Insol. Solids (IS) } \\
\text { range }(\mathrm{wt} \%)\end{array}$ \\
\hline$\overline{1}$ & $\mathrm{Ca} / \mathrm{Sr} / \mathrm{Mn}$ & $\begin{array}{l}70 \text { psig } \\
4.8 \text { bar } \\
\end{array}$ & $\begin{array}{c}13.5 \mathrm{ft} / \mathrm{s} \\
4.1 \mathrm{~m} / \mathrm{s}\end{array}$ & $\begin{array}{c}0.074 \mathrm{gpm} / \mathrm{ft}^{2} \\
4.3 \mathrm{~m}^{3} /\left(\mathrm{m}^{2} \mathrm{day}\right)\end{array}$ & 60 & 1.3 & 1.3 \\
\hline 2 & $\mathrm{Sr} / \mathrm{Mn}$ & $\begin{array}{l}50 \text { psig } \\
3.5 \text { bar }\end{array}$ & $\begin{array}{l}12.2 \mathrm{ft} / \mathrm{s} \\
3.7 \mathrm{~m} / \mathrm{s}\end{array}$ & $\begin{array}{c}0.045 \mathrm{gpm} / \mathrm{ft}^{2} \\
2.7 \mathrm{~m}^{3} /\left(\mathrm{m}^{2} \mathrm{day}\right)\end{array}$ & 73 & 3.9 & $1.8-6.8$ \\
\hline \multirow[t]{2}{*}{3} & $\mathrm{Sr} / \mathrm{Mn}$ & $\begin{array}{l}50 \text { psig } \\
3.5 \text { bar }\end{array}$ & $\begin{array}{l}12.2 \mathrm{ft} / \mathrm{s} \\
3.7 \mathrm{~m} / \mathrm{s}\end{array}$ & $\begin{array}{c}0.034 \mathrm{gpm} / \mathrm{ft}^{2} \\
2.0 \mathrm{~m}^{3} /\left(\mathrm{m}^{2} \mathrm{day}\right)\end{array}$ & 23 & 7.3 & $6.8-8.2$ \\
\hline & $\mathrm{Sr} / \mathrm{Mn}$ & $\begin{array}{l}50 \text { psig } \\
3.5 \text { bar }\end{array}$ & $\begin{array}{l}12.2 \mathrm{ft} / \mathrm{s} \\
3.7 \mathrm{~m} / \mathrm{s}\end{array}$ & $\begin{array}{c}0.030 \mathrm{gpm} / \mathrm{ft}^{2} \\
1.8 \mathrm{~m}^{3} /\left(\mathrm{m}^{2} \mathrm{day}\right)\end{array}$ & 59 & 8.2 & $7.1-9.4$ \\
\hline \multirow[t]{3}{*}{4} & $\mathrm{Sr} / \mathrm{Mn}$ & $\begin{array}{l}50 \text { psig } \\
3.5 \text { bar }\end{array}$ & $\begin{array}{l}12.2 \mathrm{ft} / \mathrm{s} \\
3.7 \mathrm{~m} / \mathrm{s}\end{array}$ & $\begin{array}{c}0.021 \mathrm{gpm} / \mathrm{ft}^{2} \\
1.2 \mathrm{~m}^{3} /\left(\mathrm{m}^{2} \mathrm{day}\right)\end{array}$ & 110 & 11.0 & $9.4-13.0$ \\
\hline & $\mathrm{Sr} / \mathrm{Mn}$ & $\begin{array}{l}50 \text { psig } \\
3.5 \text { bar }\end{array}$ & $\begin{array}{l}12.2 \mathrm{ft} / \mathrm{s} \\
3.7 \mathrm{~m} / \mathrm{s}\end{array}$ & $\begin{array}{c}0.022 \mathrm{gpm} / \mathrm{ft}^{2} \\
1.3 \mathrm{~m}^{3} /\left(\mathrm{m}^{2} \mathrm{day}\right)\end{array}$ & 30 & 13.5 & $13.0-13.9$ \\
\hline & $\mathrm{Sr} / \mathrm{Mn}$ & $\begin{array}{l}30 \text { psig } \\
2.1 \text { bar }\end{array}$ & $\begin{array}{c}15.2 \mathrm{ft} / \mathrm{s} \\
4.6 \mathrm{~m} / \mathrm{s}\end{array}$ & $\begin{array}{c}0.016 \mathrm{gpm} / \mathrm{ft}^{2} \\
0.94 \mathrm{~m}^{3} /\left(\mathrm{m}^{2} \text { day }\right)\end{array}$ & 30 & 14.5 & 14.5 \\
\hline \multirow[t]{3}{*}{5} & $\mathrm{Sr} / \mathrm{Mn}$ & $\begin{array}{l}50 \text { psig } \\
3.5 \text { bar }\end{array}$ & $\begin{array}{l}12.2 \mathrm{ft} / \mathrm{s} \\
3.7 \mathrm{~m} / \mathrm{s}\end{array}$ & $\begin{array}{c}0.023 \mathrm{gpm} / \mathrm{ft}^{2} \\
1.3 \mathrm{~m}^{3} /\left(\mathrm{m}^{2} \mathrm{day}\right)\end{array}$ & 48 & 4.3 & $3.6-5.0$ \\
\hline & $\mathrm{Sr} / \mathrm{Mn}$ & $\begin{array}{l}30 \text { psig } \\
2.1 \text { bar }\end{array}$ & $\begin{array}{l}15.2 \mathrm{ft} / \mathrm{s} \\
4.6 \mathrm{~m} / \mathrm{s}\end{array}$ & $\begin{array}{c}0.025 \mathrm{gpm} / \mathrm{ft}^{2} \\
1.5 \mathrm{~m}^{3} /\left(\mathrm{m}^{2} \mathrm{day}\right)\end{array}$ & 30 & 5.5 & $5.0-6.0$ \\
\hline & $\mathrm{Sr} / \mathrm{Mn}$ & $\begin{array}{l}40 \text { psig } \\
2.8 \text { bar }\end{array}$ & $\begin{array}{l}15.2 \mathrm{ft} / \mathrm{s} \\
4.6 \mathrm{~m} / \mathrm{s}\end{array}$ & $\begin{array}{c}0.027 \mathrm{gpm} / \mathrm{ft}^{2} \\
1.6 \mathrm{~m}^{3} /\left(\mathrm{m}^{2} \mathrm{day}\right)\end{array}$ & 43 & 6.8 & $6.0-7.7$ \\
\hline \multirow[t]{3}{*}{6} & $\mathrm{Sr} / \mathrm{Mn}$ & $\begin{array}{l}30 \text { psig } \\
2.1 \text { bar }\end{array}$ & $\begin{array}{l}9.1 \mathrm{ft} / \mathrm{s} \\
2.8 \mathrm{~m} / \mathrm{s}\end{array}$ & $\begin{array}{c}0.015 \mathrm{gpm} / \mathrm{ft}^{2} \\
0.9 \mathrm{~m}^{3} /\left(\mathrm{m}^{2} \mathrm{day}\right)\end{array}$ & 33 & 8.1 & $7.7-8.5$ \\
\hline & $\mathrm{Sr} / \mathrm{Mn}$ & $\begin{array}{l}30 \text { psig } \\
2.1 \mathrm{bar}\end{array}$ & $\begin{array}{l}15.2 \mathrm{ft} / \mathrm{s} \\
4.6 \mathrm{~m} / \mathrm{s}\end{array}$ & $\begin{array}{c}0.022 \mathrm{gpm} / \mathrm{ft}^{2} \\
1.3 \mathrm{~m}^{3} /\left(\mathrm{m}^{2} \mathrm{day}\right)\end{array}$ & 15 & 8.9 & $8.6-9.1$ \\
\hline & $\mathrm{Sr} / \mathrm{Mn}$ & $\begin{array}{l}50 \text { psig } \\
3.5 \text { bar }\end{array}$ & $\begin{array}{l}12.2 \mathrm{ft} / \mathrm{s} \\
3.7 \mathrm{~m} / \mathrm{s}\end{array}$ & $\begin{array}{c}0.018 \mathrm{gpm} / \mathrm{ft}^{2} \\
1.1 \mathrm{~m}^{3} /\left(\mathrm{m}^{2} \text { day }\right)\end{array}$ & 29 & 9.5 & $9.1-9.9$ \\
\hline \multirow[t]{4}{*}{7} & $\mathrm{Sr} / \mathrm{Mn}$ & $\begin{array}{l}25 \text { psig } \\
1.7 \text { bar }\end{array}$ & $\begin{array}{l}15.2 \mathrm{ft} / \mathrm{s} \\
4.6 \mathrm{~m} / \mathrm{s}\end{array}$ & $\begin{array}{c}0.021 \mathrm{gpm} / \mathrm{ft}^{2} \\
1.2 \mathrm{~m}^{3} /\left(\mathrm{m}^{2} \mathrm{day}\right)\end{array}$ & 30 & 10.3 & $9.9-10.6$ \\
\hline & $\mathrm{Sr} / \mathrm{Mn}$ & $\begin{array}{l}30 \text { psig } \\
2.1 \mathrm{bar}\end{array}$ & $\begin{array}{l}15.2 \mathrm{ft} / \mathrm{s} \\
4.6 \mathrm{~m} / \mathrm{s}\end{array}$ & $\begin{array}{c}0.023 \mathrm{gpm} / \mathrm{ft}^{2} \\
1.3 \mathrm{~m}^{3} /\left(\mathrm{m}^{2} \mathrm{day}\right)\end{array}$ & 30 & 11.0 & $10.6-11.4$ \\
\hline & $\mathrm{Sr} / \mathrm{Mn}$ & $\begin{array}{l}30 \text { psig } \\
2.1 \text { bar }\end{array}$ & $\begin{array}{l}15.2 \mathrm{ft} / \mathrm{s} \\
4.6 \mathrm{~m} / \mathrm{s}\end{array}$ & $\begin{array}{c}0.019 \mathrm{gpm} / \mathrm{ft}^{2} \\
1.1 \mathrm{~m}^{3} /\left(\mathrm{m}^{2} \text { day }\right)\end{array}$ & 156 & 13.1 & $11.4-14.7$ \\
\hline & $\mathrm{Sr} / \mathrm{Mn}$ & $\begin{array}{l}30 \text { psig } \\
2.1 \text { bar }\end{array}$ & $\begin{array}{l}15.2 \mathrm{ft} / \mathrm{s} \\
4.6 \mathrm{~m} / \mathrm{s}\end{array}$ & $\begin{array}{c}0.015 \mathrm{gpm} / \mathrm{ft}^{2} \\
0.9 \mathrm{~m}^{3} /\left(\mathrm{m}^{2} \mathrm{day}\right)\end{array}$ & 34 & 14.7 & $14.5-15.0$ \\
\hline
\end{tabular}

The remaining filtration discussion focuses on comparing specific conditions (e.g., different transmembrane pressures (TMP) and fluid axial velocity at constant insoluble 
WSRC-TR-2000-00506

SRT-RPP-2001-00006

BNF-003-98-0317

solids contents, different insoluble solids contents for the same TMP and axial velocity, etc.) summarized in Table 13 above.

\subsubsection{Pre- and Post-Run Clean Water Fluxes}

Figures 12 and 13 show the permeate fluxes and permeances, respectively, of the Cells Unit Filter (CUF) before and after filtration of approximately $19.8 \mathrm{~L}$ of precipitated Large $\mathrm{C}$ (AN-102) feed material.
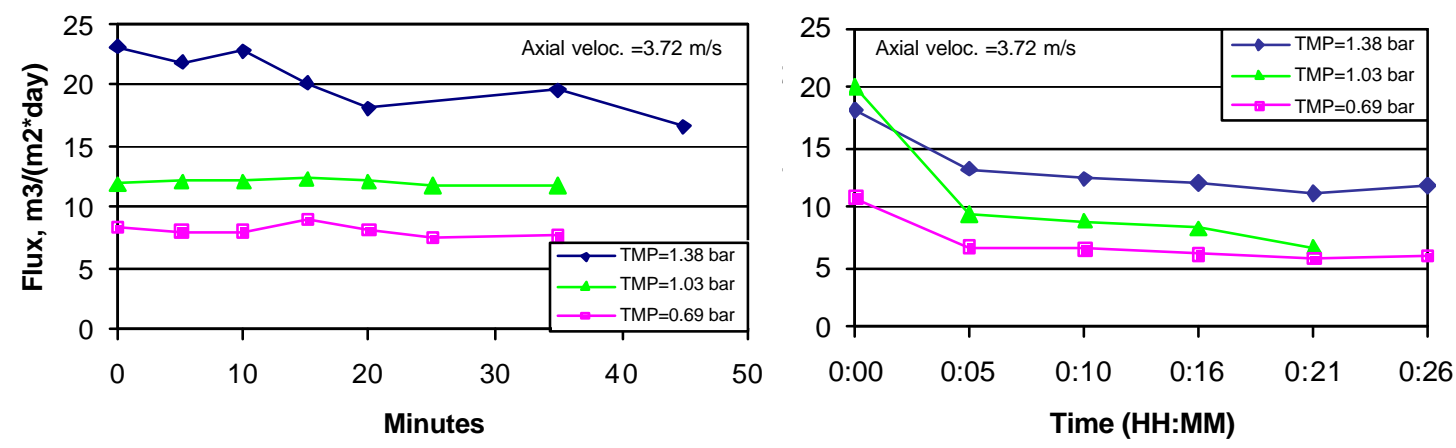

Figure 12 Clean water fluxes of the CUF from the filtration of deionized water before and after precipitated Large $C$ filtration.
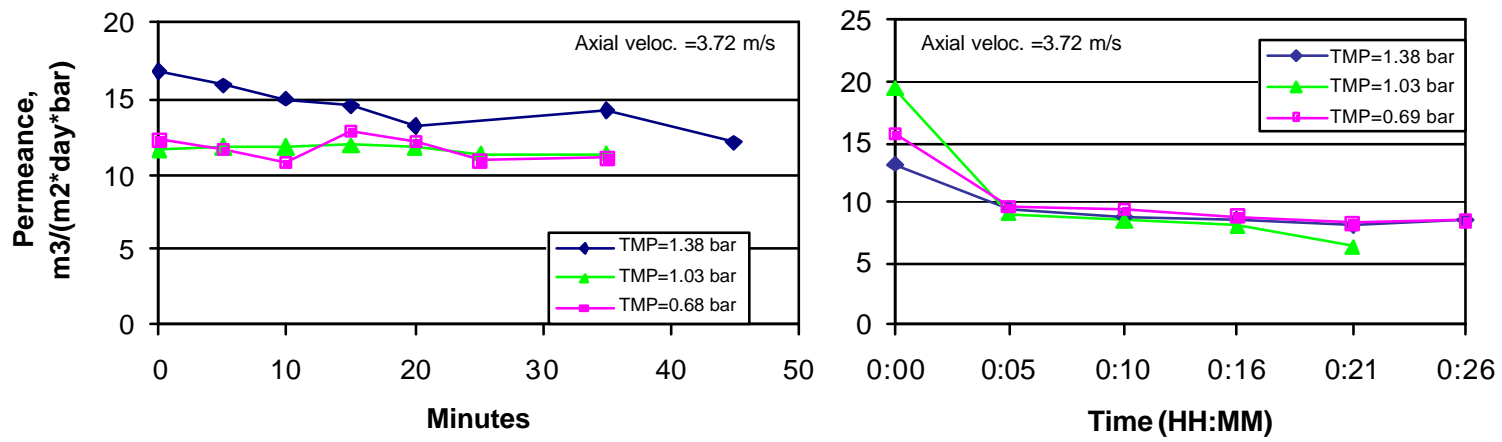

Figure 13 Clean water permeances of the CUF from the filtration of deionized water before and after precipitated Large $C$ filtration.

Of the $19.8 \mathrm{~L}$, approximately $16.4 \mathrm{~L}$ was an average $6.06 \mathrm{M} \mathrm{Na}$ Large C Envelope feed material. The axial fluid velocity for all clean water data was nominally $3.7 \mathrm{~m} / \mathrm{s}$ $(12 \mathrm{ft} / \mathrm{sec})$, and transmembrane pressures (TMP) between 0.69 and 1.38 bar (10 and $20 \mathrm{psi}$ ) were tested. The pre-run clean water fluxes are of order half those seen for the small Envelope $\mathrm{C}$ precipitation and filtration study ${ }^{21}$ performed with this equipment just prior, likely caused by some filter pore obstruction as a result of filtering entrained solids from an unprecipitated Small C AN-102 sample. 
Figures 12 and 13 suggest an approximately $25-35 \%$ deterioration in the steady state filter performance as a result of the filtration of Hanford Large Envelope C waste. However, the comparable initial fluxes obtained in both cases after backpulsing the crossflow filter indicates that the filtration of precipitated Large $\mathrm{C}$ did not permanently foul the $0.1 \mu \mathrm{m}$ Mott filter through additional pore occlusion. As a result, no adjustment of the permeate flux and permeance data due to gradually deteriorating filter performance was deemed necessary. However, the rapid degradation of both permeate flux and permeance in the post-run data soon after backpulsing of the CUF does suggest that the post-run cleaning process used does leave some solids in the CUF, likely disturbed from accumulated material in "dead" spots expected in any experimental apparatus.

\subsubsection{Ca Precipitation Data}

To further assess the filterability of precipitate from the calcium-strontium-permanganate chemistry, a 1.2 L "small" batch of Large C (AN-102) was initially precipitated and filtered in the CUF immediately after emptying water from the initial clean water flux measurements. Total solids and insoluble solids contents for this precipitated solution were $35 \mathrm{wt} . \%$ and $1.29 \mathrm{wt} . \%$, respectively. Without initially producing any filtrate, a test matrix ${ }^{22}$ varying transmembrane pressure (2.06-4.83 bar, 30-70 psi) and axial velocity $(2.77-5.03 \mathrm{~m} / \mathrm{s}, 9-16 \mathrm{ft} / \mathrm{s})$ was run, with the produced filtrate being recycled back to the CUF reservoir ("recycle" mode). Figure 14 shows all of the data in the order taken.

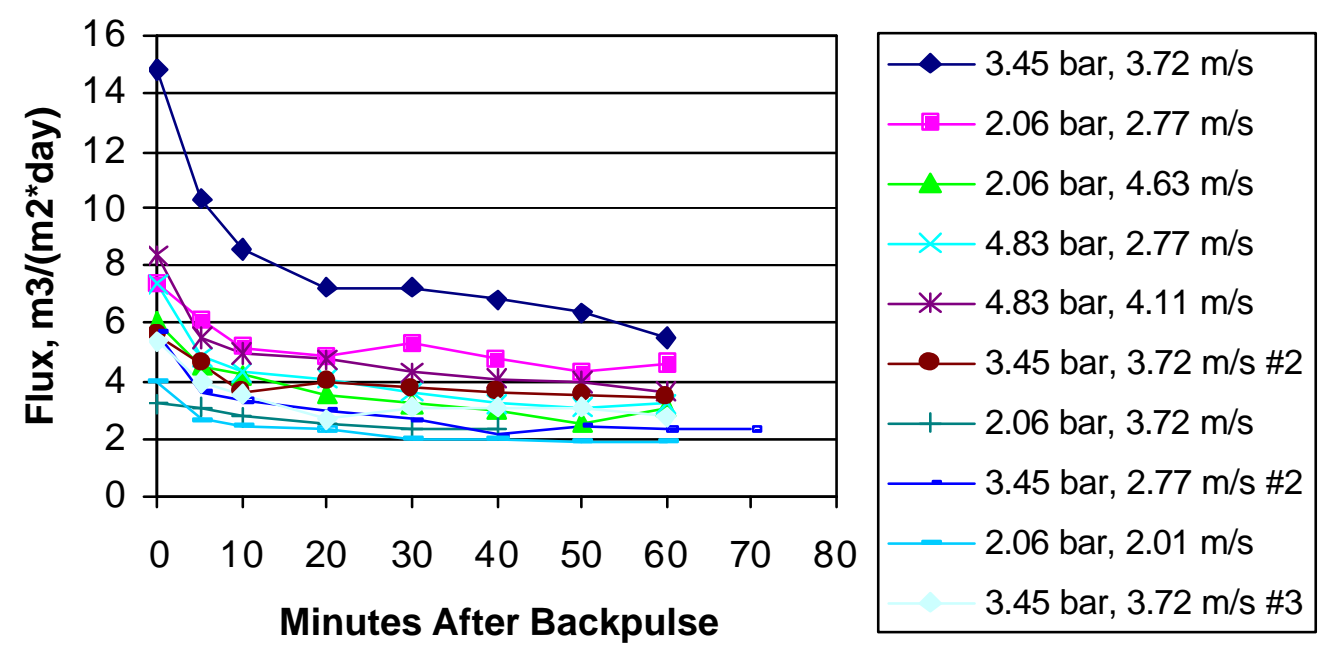

Figure 14 Permeate flux data from the $\mathrm{Ca} / \mathrm{Sr}$ nitrate and permanganate precipitated solution filtration.

Comparison of fluxes from the first two conditions ( 3.45 bar and $3.72 \mathrm{~m} / \mathrm{s}, 2.06$ bar and $2.77 \mathrm{~m} / \mathrm{s}$ ) against identical or similar conditions subsequently run suggests that those fluxes are inordinately high due to the time necessary to build up a layer of solids onto the Mott filter. Excluding these two data sets from the analysis, the expected trends were 
WSRC-TR-2000-00506

SRT-RPP-2001-00006

BNF-003-98-0317

obtained with fluxes increasing with both TMP (Figure 15) and axial velocity (Figure 16). Filter permeance is often used to measure power usage efficiency of the filtration process. Figure 17 shows that low TMP (2.06 bar, 30 psi) and high axial velocity (4.63 $\mathrm{m} / \mathrm{s}, 15 \mathrm{ft} / \mathrm{s}$ ) was the most favorable of the conditions studied.
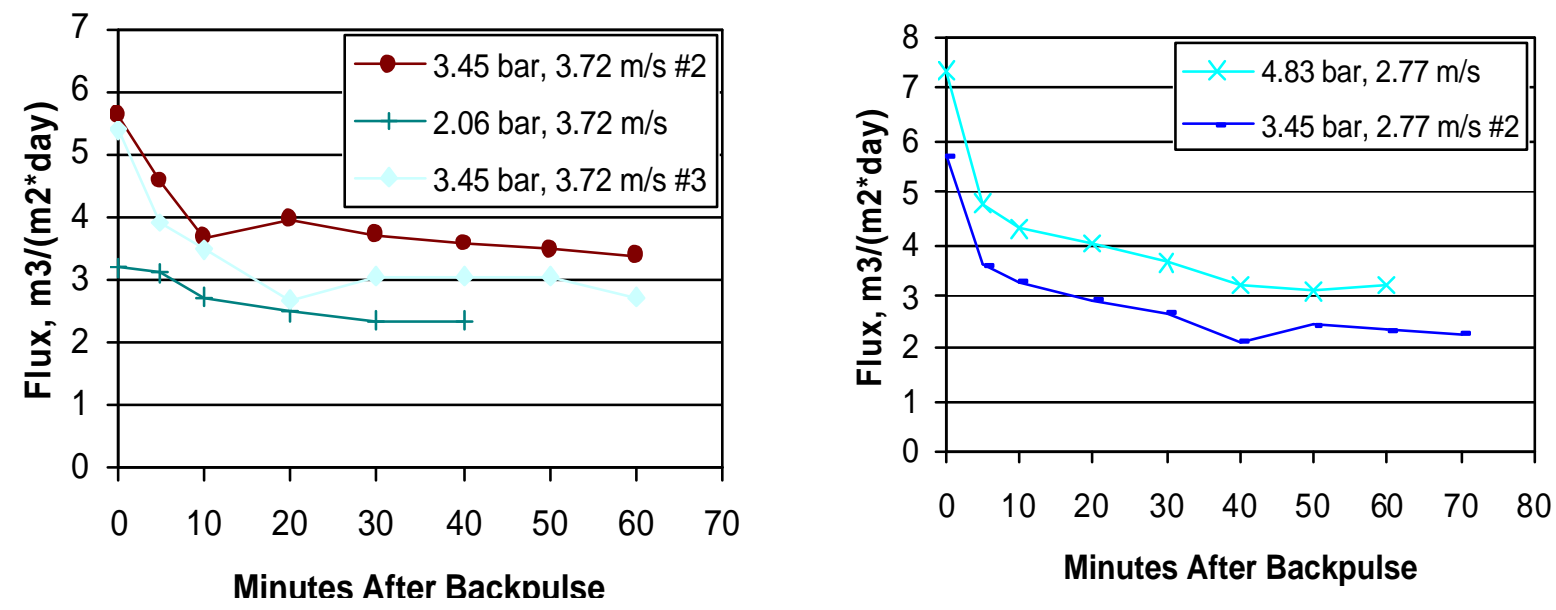

Figure 15 Permeate flux data from $\mathrm{Ca} / \mathrm{Sr}$ nitrate and permanganate precipitate filtration as affected by filter transmembrane pressure.
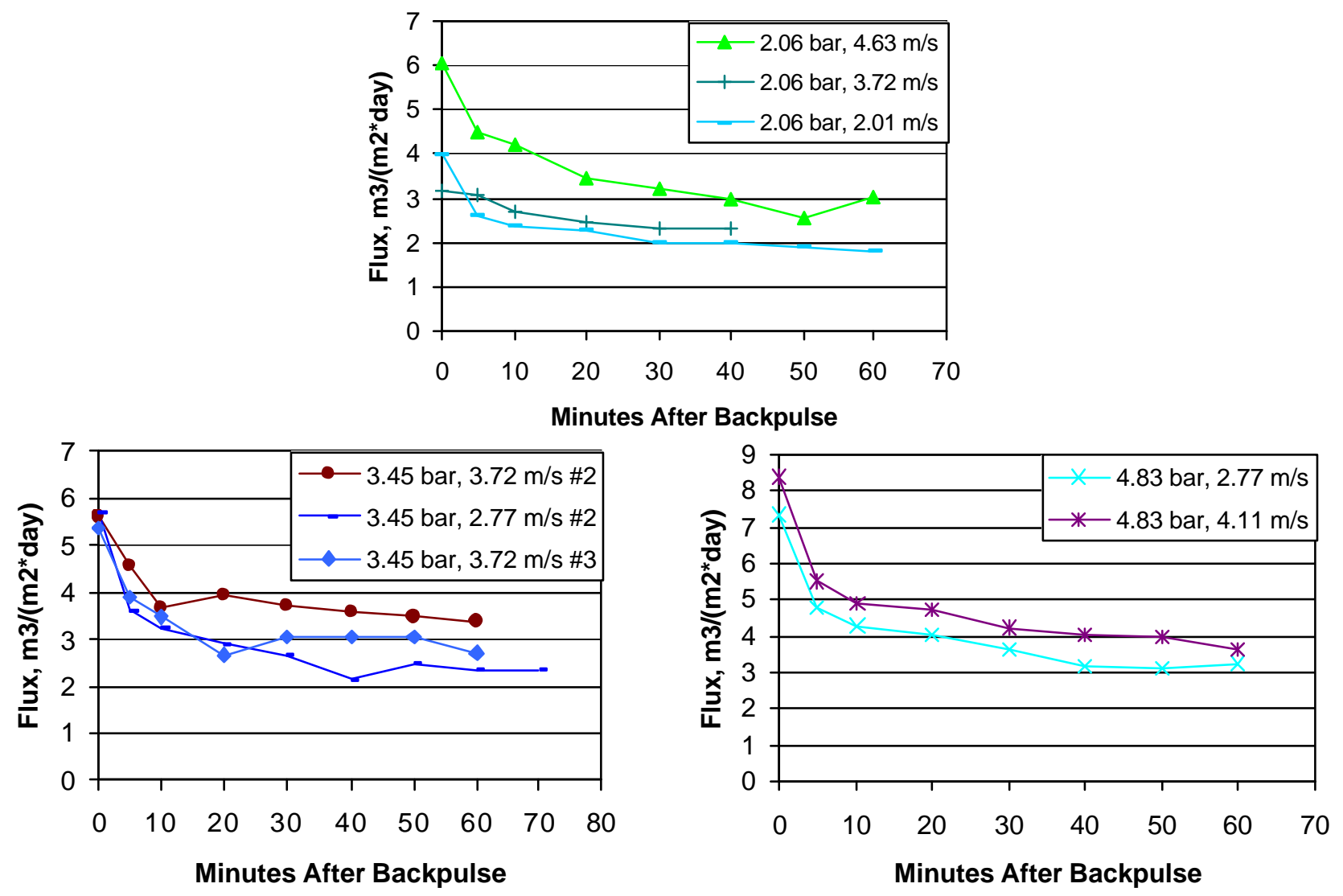

Figure 16 Permeate flux data from $\mathrm{Ca} / \mathrm{Sr}$ nitrate and permanganate precipitate filtration as affected by filter axial velocity. 


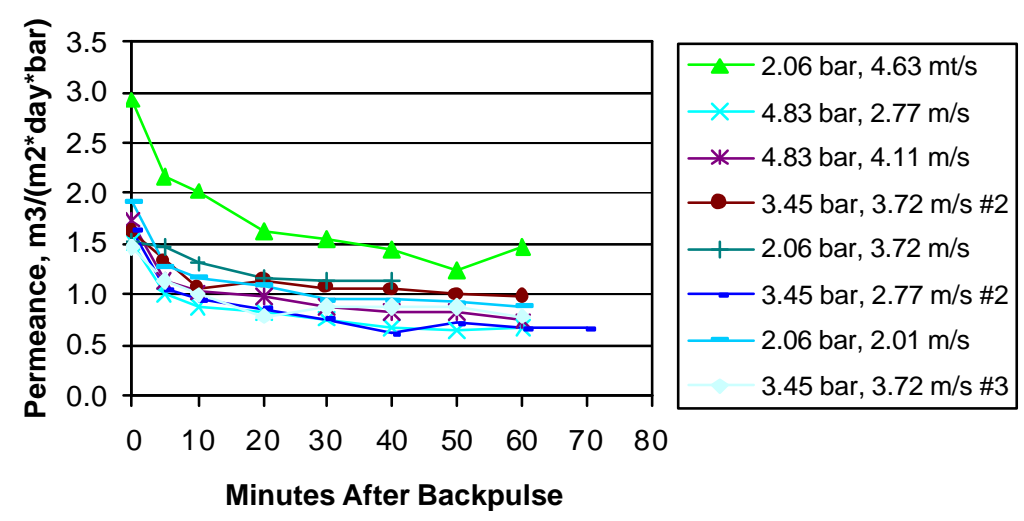

\section{Figure 17 Permeance data from the $\mathrm{Ca} / \mathrm{Sr}$ nitrate and permanganate precipitated solution filtration.}

When compared to previous work at SRTC, the steady state fluxes obtained are comparable to the approximate 1.77 to $5.87 \mathrm{~m}^{3} /\left(\mathrm{m}^{2} *\right.$ day) $\left[0.03\right.$ to $\left.0.1 \mathrm{gpm} / \mathrm{ft}^{2}\right]$ range obtained in the small C AN-102 study ${ }^{23}$ where the strontium nitrate/sodium permanganate chemistry with no calcium was used in the exact same filtering equipment used in this work. Very similar steady state permeate flux $\left(\sim 2.05-4.40 \mathrm{~m}^{3} /\left(\mathrm{m}^{2} *\right.\right.$ day $)$, $\left.\sim 0.035-0.075 \mathrm{gpm} / \mathrm{ft}^{2}\right)$ and permeance $\left(\sim 0.43-1.87 \mathrm{~m}^{3} /\left(\mathrm{m}^{2 *}\right.\right.$ day*bar $), \sim 0.0005-0.0022$ $\left.\mathrm{gpm} /\left(\mathrm{ft}^{2} * \mathrm{psi}\right)\right)$ ranges were obtained in the $\mathrm{AN}-107$ simulant pilot-scale studies containing $\sim 2 \mathrm{wt} \%$ insoluble solids performed at the Thermal Fluids Laboratory ${ }^{24}$. These steady state permeate fluxes are 3-4 times higher at the same operating conditions than those obtained immediately after backpulse when approximately 2.5 times more $\mathrm{Ca}$ and $30 \%$ more permanganate were added to a $\mathrm{AN}-107$ simulant, and a $0.2 \mu \mathrm{m}$ nominal pore diameter $1.27 \mathrm{~cm}\left(0.5\right.$ inch) ID Mott filter was used ${ }^{25}$. Investigators at PNNL cross-flow filtered an actual AN-107 sample precipitated at slightly higher $\mathrm{pH}$ (free $\mathrm{OH}^{-}$raised by 1 $\mathrm{M}$, rather than $0.875 \mathrm{M}$ here) and demonstrated near steady-state permeate fluxes of order 4.7 to $5.9 \mathrm{~m}^{3} /\left(\mathrm{m}^{2} *\right.$ day) $\left[0.08\right.$ to $\left.0.1 \mathrm{gpm} / \mathrm{ft}^{2}\right]$, although filter pore size of their filtration equipment was not reported ${ }^{26}$.

\subsubsection{High Insoluble Solids Concentration Flux Data}

The only other portion of the filtration experiment where the produced filtrate was "recycled" back to the CUF reservoir was for the collection of permeate flux data under high insoluble solids loads. The purpose of these runs was to test the effect of changing conditions around the "standard" operating conditions of TMP $=3.45$ bar (50 psi) and $3.72 \mathrm{~m} / \mathrm{s}(12 \mathrm{ft} / \mathrm{s})$ axial velocity. To produce a fluid with high insoluble solids content, freshly prepared feed material was semi-continuously pumped into the CUF reservoir to produce filtrate without concentrate being removed from the system, except for small samples. This process was carried out from mid-way through Batch \#3 (about 60\% feed 
WSRC-TR-2000-00506

SRT-RPP-2001-00006

BNF-003-98-0317

remaining) to the end of Batch \#4 to produce a fluid with a measured $45.4 \mathrm{wt} \%$ total solids and 13.9 wt.\% insoluble solids.

Upon comparison of the matrix operating conditions with the flux at "standard" conditions obtained just prior (Figure 18), raising the TMP from 3.45 to 4.83 bar (50 to $70 \mathrm{psi}$ ) has no effect on permeate flux and lowering the axial velocity only reduced the permeate production. Permeate flux and permeance increase when both the TMP is lowered to 2.06 bar (30 psi) and the axial velocity is increased from 3.72 to $4.63 \mathrm{~m} / \mathrm{s}$ (12 to $15 \mathrm{ft} / \mathrm{s})$.
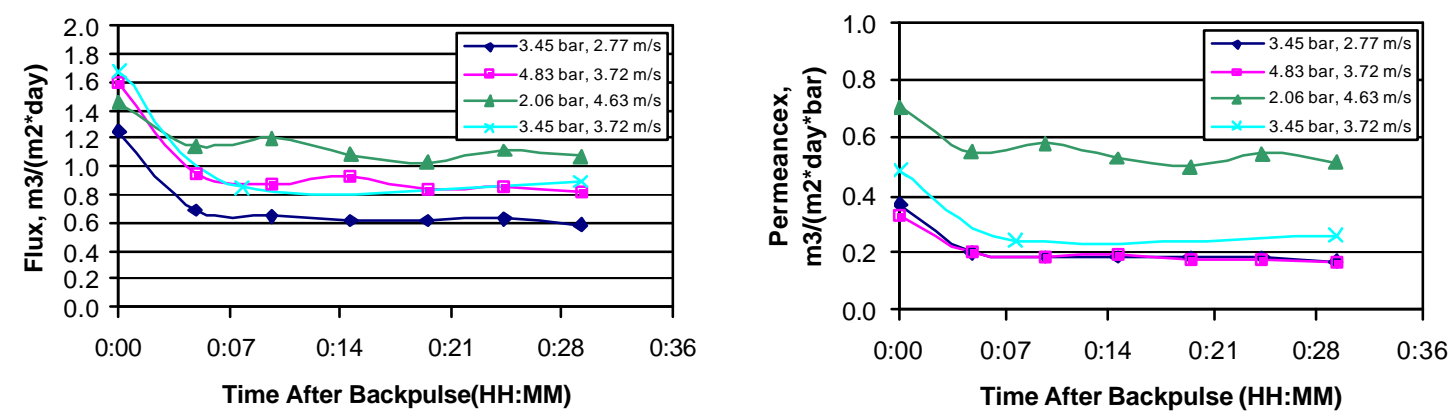

\section{Figure 18 Permeate flux and permeance from filtration of $13.9 \mathrm{wt} \% \%$ insoluble solids fluid after successive $\mathrm{Sr}\left(\mathrm{NO}_{3}\right)_{2} / \mathrm{NaMnO}_{4}$ precipitations.}

The permeate fluxes and permeances obtained experimentally are almost identical to those obtained for a $14 \mathrm{wt} \%$ insoluble solids concentrate of precipitated AN-107 Csimulant filtered at TMP=2.06 bar (30 psi), $4.63 \mathrm{~m} / \mathrm{s}(15 \mathrm{ft} / \mathrm{sec})$ and TMP=3.45 bar (50 $\mathrm{psi}), 3.72 \mathrm{~m} / \mathrm{s}(12 \mathrm{ft} / \mathrm{sec})$ in the Thermal Fluids Laboratory ${ }^{27}$.

\subsubsection{Insoluble Solids Content and Effect of Backpulse}

As expected (Figures 13-17), the filterability and the effect of the backpulse can be lessened as solids concentration rises. Some of these changes in filter performance and optimal filter operations observed were subtle. At low insoluble solids concentration, the backpulse can approximately double the initial permeate flux and permeance over the steady state values, independent of filter operating conditions. At high insoluble solids concentrations, the doubling effect is seen only for the lowest fluxes and permeances (Figure 18). At the "best" conditions (TMP=2.06 bar [30 psi] and $4.63 \mathrm{~m} / \mathrm{s}[15 \mathrm{ft} / \mathrm{s}]$ ), the backpulse effect is lessened to $\sim 40-50 \%$ improvement, likely due to more rapid solids buildup on the filter at higher solids loading or thick higher consistency slurry being less easily removed from the filter surface.

As discussed earlier, "optimal" filtrate or permeate fluxes for low insoluble solids loadings were observed with high transmembrane pressure (TMP) and high axial velocity. However for high solids content, low TMP and high axial velocity showed the 


\section{WSRC-TR-2000-00506}

SRT-RPP-2001-00006

BNF-003-98-0317

best permeate fluxes. In the case of filter permeance, low TMP and high axial velocity yielded the best values at both low and high solids concentration.

The results suggest two possible filtration strategies when concentrating insoluble solids: 1) initially begin with high TMP and high axial velocity, lowering TMP as solids concentration increases, or 2) filter continuously at low TMP and high axial velocity over the entire solids concentration range while accepting a sacrifice in permeate flux at lower solids contents.

\subsubsection{Product Data Comparisons}

Aside from the two periods discussed above where filtrate was recycled back to the CUF reservoir for low $\mathrm{Ca} / \mathrm{Sr} / \mathrm{MnO}_{4}$ solids and $\mathrm{Sr} / \mathrm{MnO}_{4}$ high solids data, the CUF was almost always being run in "production" mode where permeate was being produced and moved to $2 \mathrm{~L}$ polyethylene filtrate bottles. There were long production periods where the same identical run conditions were used, allowing for an assessment of the change of filterability over a range of insoluble solids contents. Best examples are throughout the filtration of Batches 7 ( 10-15 wt.\% insoluble solids, 2.06 bar [30 psi], $4.63 \mathrm{~m} / \mathrm{s}$ [15 $\mathrm{ft} / \mathrm{s}]), 4(\sim 10-14 \mathrm{wt} \%$ solids, $3.45 \mathrm{bar}[50 \mathrm{psi}], 3.72 \mathrm{~m} / \mathrm{s}[12 \mathrm{ft} / \mathrm{s}])$, and $2(\sim 2-7 \mathrm{wt} \%$ insoluble solids, 3.45 bar [50 psi], $3.72 \mathrm{~m} / \mathrm{s}$ [12 ft/s]).

Insoluble solids data was taken only for end-of-batch samples, and hence the insoluble solids content for much of the data was calculated. The insoluble solids were estimated by using the end-of-batch measurements and back-calculating by subtracting solids fed as precipitated $\mathrm{AN}-102$ at the prior flux measurement. It was assumed that the volume of precipitated AN-102 fed equaled the volume of filtrate produced, and the volume of filtrate produced was obtained by trapezoid-rule integration between filtrate flux data points. Precipitated AN-102 feed solids content was estimated based on 2.4 L AN-102 material becoming $2.95 \mathrm{~L}$ of precipitated feed containing $1.5 \mathrm{wt} \%$ solids, as was obtained in earlier studies. The quantity of solids formed was assumed constant in cases where the volume of $\mathrm{AN}-102$ added to the precipitation recipe was larger than $2.4 \mathrm{~L}$. Solids fed as precipitated AN-102 were estimated by multiplying volume of filtrate produced and the estimated precipitated feed insoluble solids content. An assumed CUF internal volume of $800 \mathrm{ml}$ (estimated volume observed from repeated emptying and refilling of the CUF during the experiment), a precipitated AN-102 feed density of 1.26 $\mathrm{g} / \mathrm{ml}$ (based on $\mathrm{Na}$ molarity and simulant data), and a 15-second period of filtrate production loss to fill empty CUF tubing during each flux measurement were also assumed in the calculation.

To illustrate the efficacy of this estimation method, the end of batch calculated insoluble solids contents were compared to analytically obtained results for Batches 1 and 6 . Using end of batch measured insoluble solids concentrations of 6.8 and $15.1 \mathrm{wt} \%$. for Batches 2 and 7, respectively, the calculated end of batch estimates of 1.1 and $9.5 \mathrm{wt} \%$, respectively, compared favorably with the analytically obtained values of 1.8 and 9.9 $\mathrm{wt} \%$, respectively. The calculated estimates are thought to be low due to the expected 
WSRC-TR-2000-00506

SRT-RPP-2001-00006

BNF-003-98-0317

filtrate volume over-estimation by trapezoid rule integration as well as the rough nature of the $1.5 \mathrm{wt} \%$ precipitated feed solids estimate, although there is also some uncertainty in the end and beginning of run insoluble solids analytical measurements.

Table 14. Measured vs. Calculated Insoluble Solids Content for CUF Concentrate (End of Precipitation Batch)

\begin{tabular}{|c|c|c|}
\hline \multirow{2}{*}{ Batch \# } & \multicolumn{2}{|c|}{ End of Batch Insoluble Solids Content (wt\%) } \\
\cline { 2 - 3 } & Measured & Calculated Backward \\
\hline 1 & 1.8 & 1.1 \\
\hline 2 & 6.8 & (HIGHCONC1 $^{*}$ ) \\
\hline 3 & ----- & $9.4,10.0$ \\
\hline 4 & $13.9,14.5$ & (HIGHCONC2*) \\
\hline 5 & 7.7 & (HIGHCONC3 $)$ \\
\hline 6 & 9.9 & 9.5 \\
\hline 7 & 15.1 & ----- \\
\hline \multicolumn{2}{|c|}{$*$ Could not calculate due to uncertain quantities before } \\
draining CUF into bottle HIGHCONC $x$
\end{tabular}

In the filtration of Batch 7, transmembrane pressure and axial velocity were nominally $2.06 \mathrm{bar}(30 \mathrm{psi})$ and $4.63 \mathrm{~m} / \mathrm{s}(15 \mathrm{ft} / \mathrm{s})$, respectively. Figure 19 shows that increasing insoluble solids content reduces the permeate fluxes obtained when concentrating between calculated solids contents of 10.3 and $15.0 \mathrm{wt} . \%$. Also a continuous decline in permeate flux as solids are concentrated was seen. The effect of CUF restarts without backpulsing was also examined (Figure 19) at high insoluble solids concentration, where restarts such as between the 12.1 and 12.2 wt.\% solids data points do show some potential to restore higher permeate fluxes temporarily, but the improvements will likely be several times below that of a backpulse. Permeance data was found to mirror the permeate flux data. Concentrations ranged from 9.5 to $10.2 \mathrm{wt} . \%$ (calculated) using TMP=1.72 bar ( $25 \mathrm{psi})$ and axial velocity of $4.63 \mathrm{~m} / \mathrm{s}(15 \mathrm{ft} / \mathrm{s})$, not shown, was tested but yielded a lower steady state flux $\left(\sim 12.3 \mathrm{~m}^{3} /\left(\mathrm{m}^{2} *\right.\right.$ day $)\left[\sim 0.21 \mathrm{gpm} / \mathrm{ft}^{2}\right]$ compared to $\sim 13.5$ $\mathrm{m}^{3} /\left(\mathrm{m}^{2}\right.$ *day) $\left[\sim 0.23 \mathrm{gpm} / \mathrm{ft}^{2}\right]$ at $\mathrm{TMP}=2.06$ bar [30 psi] immediately after) and caused large fluctuations $( \pm 10-15 \mathrm{psi})$ in P1 leading to test discontinuance.

Filtration of Batch 4, operated nominally at TMP=3.45 bar (50 psi) and $3.72 \mathrm{~m} / \mathrm{s}(12 \mathrm{ft} / \mathrm{s})$ axial velocity and concentrating the solution from a calculated $10.3 \mathrm{wt} \%$ to an analytically measured 13.9 wt.\%, confirms the observations at high insoluble solids concentration seen in Batch 7 filtration. Again, permeate flux decreased with increasing insoluble solids content, with a steady decline as insoluble solids levels increased, and CUF restarts without a backpulse only slightly increases permeate flux compared to a backpulse. Calculated permeances again mirrored the trends in the permeate flux. When Figures 19 and 20 are compared, very similar fluxes are obtained over the similar insoluble solids content ranges at both operating conditions. 
WSRC-TR-2000-00506

SRT-RPP-2001-00006

BNF-003-98-0317
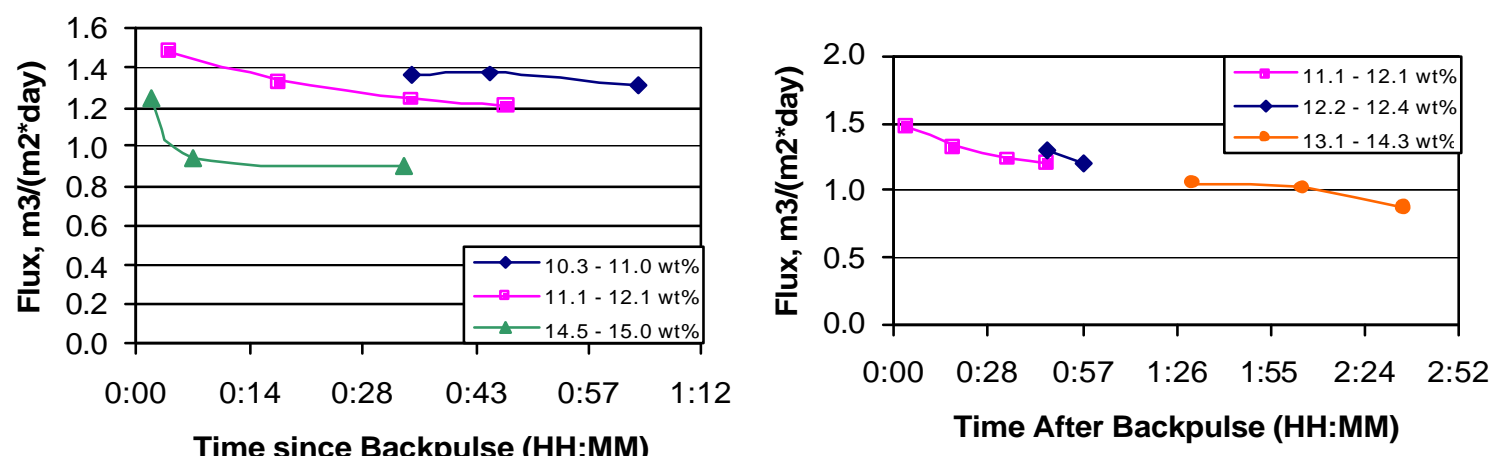

Figure 19 Permeate flux during filtration of Batch 7 as affected by high insoluble solids content, and as affected by restart without backpulse. TMP = 2.06 bar $(30 \mathrm{psi})$, axial velocity $=4.63 \mathrm{~m} / \mathrm{s}(15 \mathrm{ft} / \mathrm{s})$, nominally .

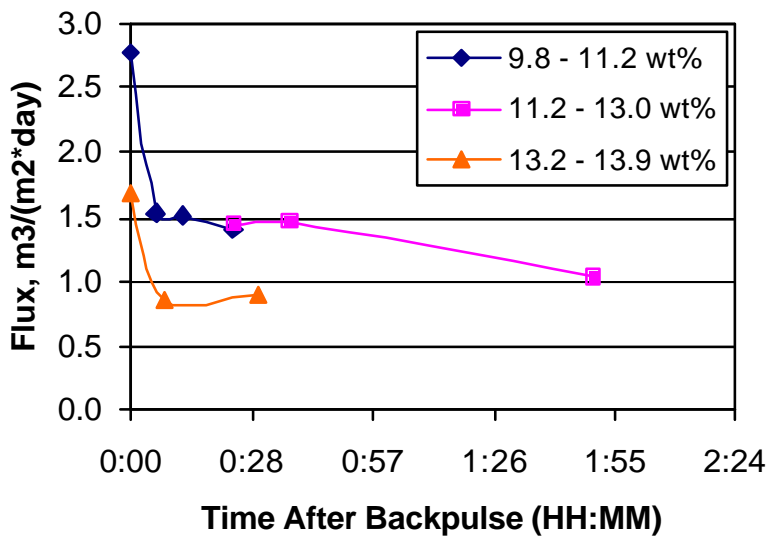

Figure 20 Permeate flux during filtration of Batch 4 as affected by high insoluble solids content, and as affected by restart without backpulse. TMP = 3.45 bar (50 psi), axial velocity $=3.72 \mathrm{~m} / \mathrm{s}(12 \mathrm{ft} / \mathrm{s})$, nominally.

A similar analysis was done for Batch \#2 filtration data at lower insoluble solids loadings at TMP=3.45 bar (50 psi) and $3.72 \mathrm{~m} / \mathrm{s}(12 \mathrm{ft} / \mathrm{s})$ axial velocity. Figure 21 shows that filtration behavior is very different at low rather than high insoluble solids concentrations. The "spike" between the second $(3.9-4.5$ wt $\%$ insoluble solids, calculated) and third ( $4.5-6.3 \mathrm{wt} \%$ insoluble solids, calculated) curves illustrates that a CUF restart without a backpulse acts in the same way as a backpulse in restoring higher permeate fluxes. If the third curve is displaced left by 7 minutes, this and the first curve $(1.1-3.8 \mathrm{wt} \%$ insoluble solids, calculated) overlap indicating that permeate fluxes are essentially independent of insoluble solids content in the $\sim 1.5-6.5 \mathrm{wt} \%$ range. 
WSRC-TR-2000-00506

SRT-RPP-2001-00006

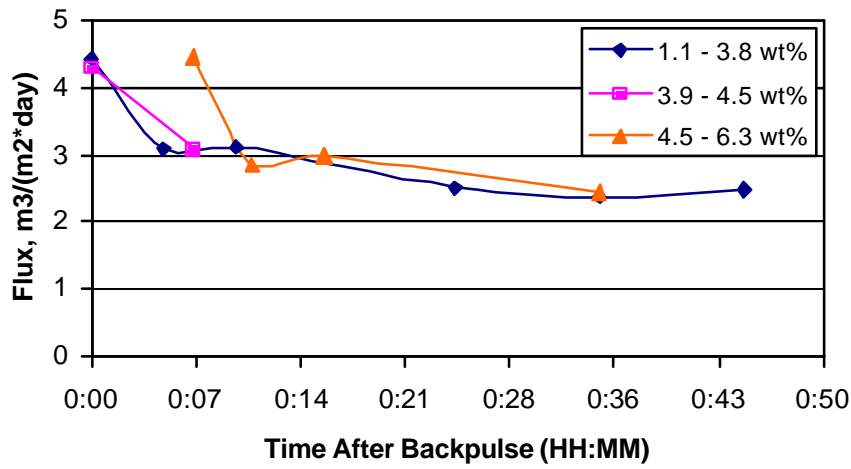

BNF-003-98-0317

Figure 21 Permeate flux during filtration of Batch 2 as affected by low insoluble solids content, and as affected by restart without backpulse. TMP $=3.45 \mathrm{bar}(50 \mathrm{psi})$, axial velocity $=3.72 \mathrm{~m} / \mathrm{s}(12 \mathrm{ft} / \mathrm{s})$, nominally.

The initial filtration of Batch 3 began without a backpulse and a simple restart of the CUF. Comparison of Figures 21 and 22 indicates that CUF restart begins to lose effectiveness as a backpulse substitute in restoring higher permeate fluxes at insoluble solids loadings above $6.8 \mathrm{wt} \%$, and the steady state flux has also begun to drop. The calculated insoluble solids concentrations in Figures 21 and 22 are based on an analytically measured value of $6.8 \mathrm{wt} \%$ obtained for an end of Batch 2 filtration concentrate sample.

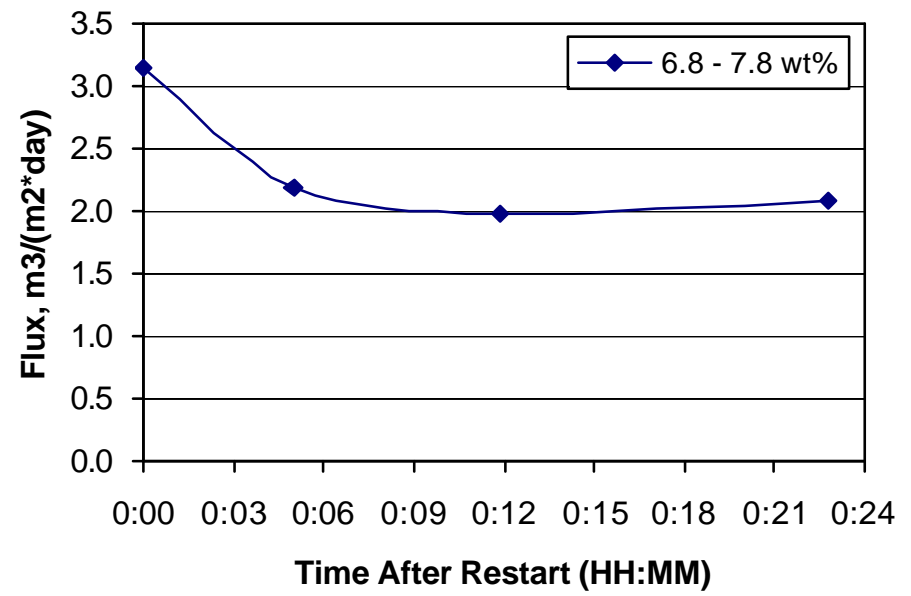

Figure 22 Permeate flux data at the beginning of Batch 3 filtration. TMP = $3.45 \mathrm{bar}(50 \mathrm{psi}), 3.75 \mathrm{~m} / \mathrm{s}(12 \mathrm{ft} / \mathrm{s})$ axial velocity, nominal.

Due to the difficulty in obtaining concentrate samples from the CUF for solids analysis, the opportunities to perform direct comparisons of the data without calculating insoluble solids content are very few. In the data collected, the most suitable comparison that can be made is of the high insoluble solids concentration flux data discussed previously (13.9 and $14.5 \mathrm{wt} . \%$ by independent analyses) and the flux data at the end of Batch 7 (finishing with 15.1 wt.\%). Both were filtered at TMP $=2.06$ bar (30 psi) and $4.63 \mathrm{~m} / \mathrm{s}$ 
WSRC-TR-2000-00506

SRT-RPP-2001-00006

BNF-003-98-0317

$(15 \mathrm{ft} / \mathrm{s})$ axial velocity. The insoluble solids contents for both slurries were obtained analytically. Figure 23 compares filterability at the two conditions (permeance data mirrored the permeate flux data). The lower permeate flux at the end of Batch 7 is likely due to the slightly higher insoluble solids content.

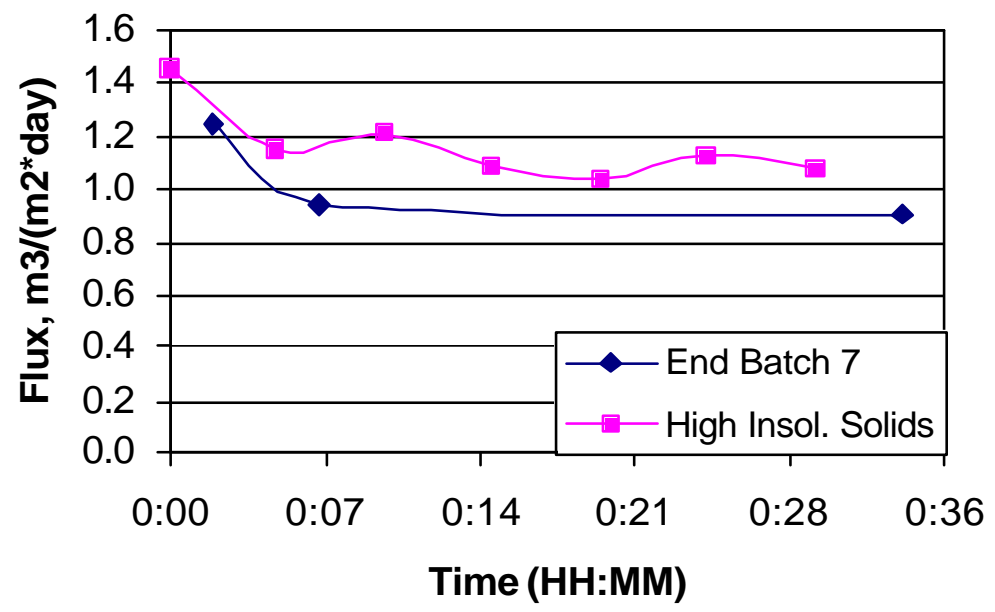

Figure 23 Permeate flux comparison between flux data taken at high insoluble solids concentration and at the end of Batch 7. TMP = 2.06 bar (30 psi), 4.63 (15 ft/s) nominal axial velocity.

\subsubsection{Reduced Reagent Precipitation Batch}

The optimization study by Rosencrance ${ }^{28}$ recommended high hydroxide $(1 \mathrm{M})$, strontium $(0.075 \mathrm{M})$, and permanganate $(0.05 \mathrm{M})$ addition to maximize $\mathrm{Sr} / \mathrm{TRU}$ removal and filterability of treated AN-102. Currently, Sr-90 removal is thought to be removed by isotopic dilution and TRU removal by co-precipitation with manganese dioxide. To challenge these mechanisms and observe process sensitivity to precipitant addition levels, Batch \#6 of the AN-102 Hanford waste was treated with a lower than recipe-specified precipitant quantities. Additionally as the full-scale process is expected to batch precipitate on top of recycled cross-flow filter concentrate until $20 \mathrm{wt} \%$ insoluble solids is attained in the precipitation tank, a test of the $\mathrm{Sr} / \mathrm{MnO}_{4}$ precipitation with pre-existing $\mathrm{Sr} / \mathrm{MnO}_{4}$ chemistry insoluble solids was also sought since this aspect has not been studied previously. Hence, a $700 \mathrm{~mL}$ portion of the concentrate produced in Batch \#5 was included with 1.7 L fresh AN-102 feed material prior to addition of strontium nitrate and sodium permanganate in Batch \#6.

In detail, at the end of Batch \#5 with nearly $1 \mathrm{~L}$ feed remaining, the CUF was drained of concentrate and the CUF refilled with feed. The concentrate was then mixed with approximately $400 \mathrm{ml}$ of remaining Batch \#5 feed to yield approximately $1 \mathrm{~L}$ of slurry. Of this feed/concentrate mixture, approximately $300 \mathrm{ml}$ was used to "top off" the CUF. To the remaining $\sim 700 \mathrm{ml}$ feed/concentrate, $1700 \mathrm{ml}$ of untreated AN-102 material was added to the $4 \mathrm{~L}$ Erlenmeyer, followed by $\sim 220 \mathrm{ml}$ of $\sim 0.3 \mathrm{M} \mathrm{Sr}\left(\mathrm{NO}_{3}\right)_{2}$ and $\sim 147 \mathrm{ml} \sim 0.4$ 


\section{WSRC-TR-2000-00506}

SRT-RPP-2001-00006

BNF-003-98-0317

$\mathrm{M} \mathrm{NaMnO}_{4}$. These reduced quantities of precipitating agents and feed translate to nominally $\sim 2 \% \mathrm{Sr}\left(\mathrm{NO}_{3}\right)_{2}$ and $\sim 56 \% \mathrm{NaMnO}_{4}$ of the recipe cited in the Experimental section. The final total strontium and manganese concentrations (Table 7) of 0.040 and $0.041 \mathrm{M}$, respectively, represent a "middle-middle" addition level cited by Rosencrance above as acceptable for filterability.

Similar to the end of Batch \#7 where permeate fluxes had slowed, filtration of Batch 6 was also interrupted and the CUF contents emptied due to slow permeate production rates. The steady state permeate flux in Batch \#6 dropped to $0.56 \mathrm{~m}^{3} /\left(\mathrm{m}^{2} *\right.$ day $)[0.010$ $\left.\mathrm{gpm} / \mathrm{ft}^{2}\right]$ by the time the calculated insoluble solids content in the CUF concentrate had risen to 10.1 wt.\% (8.7 \pm 0.4 wt.\% by analytical measurement), compared to 0.9 $\mathrm{m}^{3} /\left(\mathrm{m}^{2} *\right.$ day $)\left[0.015 \mathrm{gpm} / \mathrm{ft}^{2}\right]$ when the concentrate insoluble solids content rose to $14.6-$ 15.1 wt.\% for Batch \#7. Hence, the effect of precipitating with lower precipitating agent quantities appeared to significantly lower the filterability of the resulting precipitated slurry despite the contribution of filterable Batch \#5 insoluble solids.

To help elucidate the quantity of insoluble solids formed as a function of precipitating reagent input, a comparison of measured and calculated insoluble solids concentration was performed for sample HIGHCONC3 as was done in the previous section for end-ofbatch insoluble solids levels. HIGHCONC3 was a thick concentrate produced and drained from the CUF during Batch \#6. In this case, the end of Batch \#5 insoluble solids content of $7.7 \mathrm{wt} \%$ was used as a starting point, and the insoluble solids content was calculated forward based on filtrate production. A linear scaling assumption for precipitate generation was used, where an estimated $35 \%$ of the typical $1.5 \mathrm{wt} \%$ insoluble solids per batch was generated since $30 \%$ and $40 \%$ of the typical quantities of $\operatorname{Sr}\left(\mathrm{NO}_{3}\right)_{2}$ and $\mathrm{NaMnO}_{4}$, respectively, were added. Although there is some uncertainty in the measurements (data ranged from $8.4-9.0 \mathrm{wt} . \%$ ), the $10.1 \mathrm{wt} \%$ calculated insoluble solids content suggests that the linear scaling assumption likely overestimates insoluble solids production, and that a certain minimum precipitant addition threshold must be attained before significant precipitated solids are generated.

\subsubsection{Insoluble Solids Wash Runs}

At the end of the production of filtered precipitated feed, a high insoluble-solids content (15.1 wt\%), highly-viscous concentrate was then washed with four aliquots of $0.01 \mathrm{M}$ $\mathrm{NaOH}$ (inhibited water) to remove interstitial Hanford liquids. In each wash step, $600 \mathrm{ml} 0.01 \mathrm{M} \mathrm{NaOH}$ was added to the CUF reservoir to produce $\sim 600 \mathrm{ml}$ of filtrate at TMP $=30 \mathrm{psi}$ and $15 \mathrm{ft} / \mathrm{s}$ axial velocity, the optimal filtration conditions identified for high-insoluble solids content fluids. The only exception was Wash Run \#4, where the "standard" conditions of $50 \mathrm{psig}$ and $12 \mathrm{ft} / \mathrm{s}$ were used. Figure 24 shows that the low TMP and high axial velocity continued to be favorable compared to the "standard." 

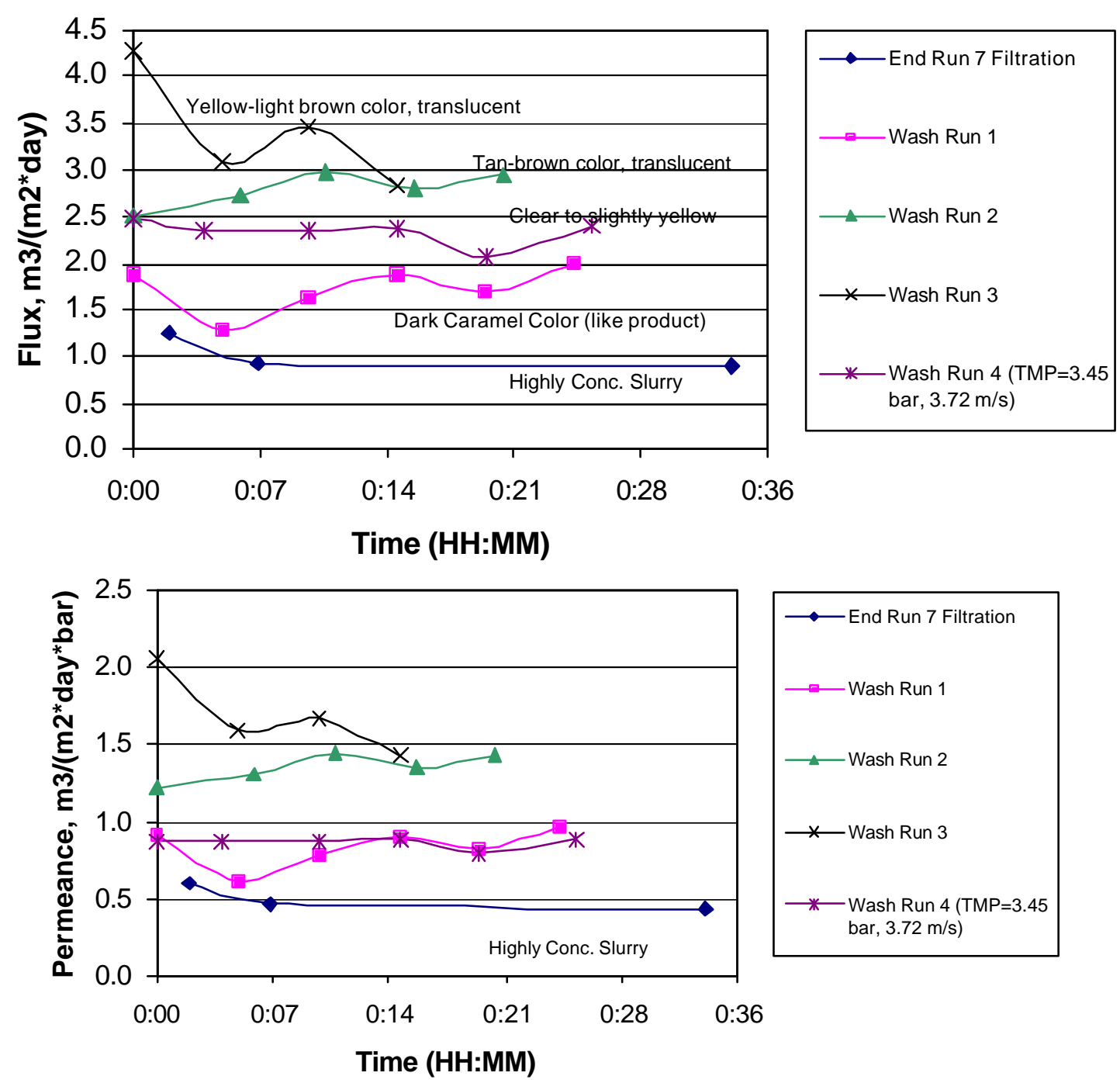

Figure 24 Permeate flux and permeance of each $0.01 \mathrm{M} \mathrm{NaOH}$ solution wash vs. the end of filtration results.

With each successive wash, permeate flux and permeance increased with the third wash yielding up to 3-4 times the flux obtained just at the end of precipitate filtration. Each wash also yielded successively lighter filtrates starting from a dark caramel to a yellowish-light brown liquid (uncorrected for color skew from Shielded Cell window and halogen lighting). Each filtrate produced was a translucent liquid, except for the second wash which showed only a slight trace of a "fluffy" dark solids at the bottom of the sample bottle. The CUF concentrate insoluble solids content drop from $15.1 \mathrm{wt} \%$ at the end of filtration to the $12.8 \mathrm{wt} \%$ ( $1 \mathrm{wt} \%$ std. dev.) at the end of the four washes, along with the successive loss of filtrate color, does suggest that some solids or salts are being removed during each wash step. 


\section{WSRC-TR-2000-00506}

SRT-RPP-2001-00006

BNF-003-98-0317

The total solids concentration of the CUF concentrate after washes was $16.6 \mathrm{wt} \%$ (0.16 wt \% std. dev.), indicating that deactivated water ( $\sim .04 \mathrm{wt} \%$ calculated total solids) has replaced of order $90-95 \%$ of the salt-laden supernatant liquid/filtrate. The expected replacement percentage was expected to be $95 \%$, based on washing with 3 CUF internal volumes and assuming the CUF is well-stirred. Another interesting observation was that the CUF recirculation pump could not be easily restarted after completing the last wash indicating poor flow characteristics of the wash slurry.

\subsubsection{Task Plan Deviations}

As cited in Section 3.2 "Precipitation Recipes", the added free hydroxide was 0.95 and $1.0 \mathrm{M}$ for the $\mathrm{Ca} / \mathrm{Sr} / \mathrm{MnO}_{4}$ and $\mathrm{Sr} / \mathrm{MnO}_{4}$ precipitation chemistry recipes, respectively, rather than the $0875 \mathrm{M}$ additional free hydroxide target.

The cross-flow filtration experiments was performed per the specifications and Table 2 in the Technical Task Plan cited in the Introduction with a few deviations in the prescribed tests noted in Table 15 (next page). The transmembrane pressures in Tests 1-3 and 25 were reduced to obtain fluxes more similar to actual operating conditions. In Test 10, the transmembrane pressure was reduced from 40 to $30 \mathrm{psi}$ ( 2.76 to $2.06 \mathrm{bar}$ ) as the system was found to be less sensitive to TMP than expected.

As TMP=50 psi (3.45 bar) and $12.2 \mathrm{ft} / \mathrm{s}(3.72 \mathrm{~m} / \mathrm{s})$ was determined to be the "optimum" conditions at that time (for Test 13), Tests 10-12 were modified to examine the effect of reduced axial velocity and/or transmembrane pressure. Test 14 was omitted as increased TMP was not found earlier to increase permeate flux, and Tests 15-16 were not performed as these duplicated earlier conditions.

As dewatering in Test 17 was performed at TMP $=50$ psi $(3.45 \mathrm{bar})$ and $12.2 \mathrm{ft} / \mathrm{s}(3.72$ $\mathrm{m} / \mathrm{s}$ ), Tests 18-20 became a study to quantify the effects of increased TMP (Test 20 unchanged), reduced axial velocity (Test 19), and a combination of reduced TMP and higher axial velocity (Test 18 ) at higher insoluble solids loading.

Tests 21-22 were deemed unnecessary, since TMP $=30 \mathrm{psi}(2.06 \mathrm{bar})$ and $15.2 \mathrm{ft} / \mathrm{s}$ $(4.63 \mathrm{~m} / \mathrm{s})$ was observed to yield the highest permeate flux and the CUF pump was beginning to labor.

Rheology measurements for samples of insoluble solids concentrates remaining in the CUF after filtration of Batches 1, 4 and 7 were performed, and the results are cited in a separate report by Rosencrance ${ }^{29}$. 
WSRC-TR-2000-00506

SRT-RPP-2001-00006

BNF-003-98-0317

Table 15 Technical Task Plan (Table 2) with deviations noted in parentheses

\begin{tabular}{|c|c|c|c|}
\hline Test no. & Sample & $\begin{array}{c}\text { Transmembrane pressure } \\
\text { (psi) }\end{array}$ & Crossflow Velocity (ft/s) \\
\hline 1 & Demin water & $30(10)$ & 12.2 \\
\hline 2 & Demin water & $40(15)$ & 12.2 \\
\hline 3 & Demin water & $55(20)$ & 12.2 \\
\hline 4 & Feed & 50 & 12.2 \\
\hline 5 & Feed & 30 & 9.1 \\
\hline 6 & Feed & 30 & 15.2 \\
\hline 7 & Feed & 70 & 9.1 \\
\hline 8 & Feed & 70 & $12.2-15.2$ \\
\hline 9 & Feed & 50 & 12.2 \\
\hline 10 & Feed & $40(30)$ & 12.2 \\
\hline 11 & Feed & $55(50)$ & $12.2(9.1)$ \\
\hline 12 & Feed & $70(30)$ & $12.2(6.6)$ \\
\hline 13 & Feed & optimum from 4-12 (50) & $9.1(12.2)$ \\
\hline 14 & Feed & $\begin{array}{l}\text { optimum from } \\
4-12 \text { (omitted) }\end{array}$ & 15.2 (omitted) \\
\hline 15 & Feed & 55 (omitted) & 12.2 (omitted) \\
\hline 16 & Feed & 30 (omitted-see 12) & 6.6 (omitted-see 12) \\
\hline 17 & De-watering & optimum from 4-12 & Optimum from 4-16 \\
\hline 18 & Solids Concentration & $40(30)$ & $12.2(15.2)$ \\
\hline 19 & Solids Concentration & $55(50)$ & $12.2(9.1)$ \\
\hline 20 & Solids Concentration & 70 & 12.2 \\
\hline 21 & Solids Concentration & $\begin{array}{l}\text { optimum from } \\
18-20 \text { (omitted) }\end{array}$ & 9.1 (omitted) \\
\hline 22 & Solids Concentration & $\begin{array}{l}\text { optimum from } \\
18-20 \text { (omitted) }\end{array}$ & 15.2 (omitted) \\
\hline 23 & De-watering & $\begin{array}{l}\text { optimum from } \\
18-22(\mathbf{3 0})\end{array}$ & $\begin{array}{l}\text { Optimum from } \\
18-22(\mathbf{1 5 . 2 )}\end{array}$ \\
\hline 24 & Acid Clean & $\mathrm{N} / \mathrm{A}$ & $\mathrm{N} / \mathrm{A}$ \\
\hline 25 & $\begin{array}{l}\text { Demin water (post } \\
\text { acid clean) }\end{array}$ & $40(10,15,20)$ & 12.2 \\
\hline
\end{tabular}

\subsection{CONCLUSIONS}

\section{Precipitation Chemistry Study}

- The most significant observation on decontamination was that the level of reagent additions were found to be conservatively large. The low level composite filtrate had about one seventh the Sr-90 activity and one quarter of the TRU activity permitted for low level glass loading. This shows that reduced reagent addition will be permissible for the flowsheet. 


\section{WSRC-TR-2000-00506}

SRT-RPP-2001-00006

BNF-003-98-0317

- Removal or passage of elements match past observations. Al, B, Cd, Mo, Na, Ni, $\mathrm{S}$, and $\mathrm{P}$ were not removed. Very small amounts of $\mathrm{Ca}, \mathrm{Cr}, \mathrm{Pb}$, and $\mathrm{Zn}$ were removed. About $80 \%$ of the $\mathrm{Fe}$ is removed.

- This process does not remove technetium-99 from the solution.

- Am-241 does not wash out of the slurry during washing; plutonium shows some washout behavior.

- Nitric acid showed some effectiveness over water alone in dissolving residual matter in the filter rig.

Filterability Study

- At low insoluble solids levels, high transmembrane pressure and high axial velocity favors filterability, although the effect of transmembrane pressure is smaller. Permeance data suggests highest energy usage efficiency at low transmembrane pressure and high axial velocity.

- At high insoluble solids levels ( $14 \mathrm{wt} \%)$, low transmembrane pressure (2.06 bar, $30 \mathrm{psi})$ and high axial velocity $(4.63 \mathrm{~m} / \mathrm{s}, 15 \mathrm{ft} / \mathrm{s})$ favors filterability.

- Cells Unit Filter (CUF) restart is equivalent to a backpulse up to $\sim 7$ wt.\% insoluble solids, in providing higher initial fluxes.

- Washing of solids filterability is best at low transmembrane pressure and high axial velocity, with flux increasing with increased rinsing with inhibited water.

- No significant difference in filterability was observed when the calcium nitratestrontium nitrate-sodium permanganate strike data obtained was compared with previous literature for the strontium nitrate-sodium permanganate chemistry.

- Although no data was obtained to directly address the design basis filter flux "optimum" of $3.8 \mathrm{~m}^{3} / \mathrm{m}^{2} *$ day $\left(0.065 \mathrm{gpm} / \mathrm{ft}^{2}\right)$ for a Tank AN-102 waste with $2 \%$ insoluble solids (P. Townson, BNFL Memorandum CCN \#011449, March 17, 2000), similar filter fluxes were experimentally obtained. Extensive data at 1.3 wt $\%$ insoluble solids presented in this study suggests the optimum is possible, but production data at $1.1-3.8 \mathrm{wt} \%$ insoluble solids was not encouraging. However, this experimental data was taken with largely unprecipitated solids which are expected to be less filterable than those from the $\mathrm{Sr} / \mathrm{MnO}_{4}$ chemistry. 


\subsection{RECOMMENDATIONS}

BNF-003-98-0317

- Future testing of the strontium and permanganate process should focus on reduction of added strontium and permanganate while still producing low level filtrate. Reduced levels of sodium hydroxide in the initial caustic adjustment would also provide a benefit of adding less sodium to the low level glass. It is possible that the precipitation reagents do not consume free hydroxide, though some is needed to assure that aluminum does not precipitate.

- Darkening of filtrate product bottles indicated some post-precipitation mechanism. This mechanism needs further study.

- Precipitation at lower temperatures need investigation for practicality. While not a focus of the current study, some room temperature precipitation has been tested in past "beaker" studies and would simplify the process.

- Rheology of the (sheared) precipitate at $15-20 \mathrm{wt} \%$ insoluble solids needs study. The $15 \mathrm{wt} \%$ material caused pumping difficulties in the narrow tubing of the cells filter unit.

- Backpulse frequency needs to be investigated to improve overall average filter fluxes.

\subsection{REFERENCES}

${ }^{1}$ Herting, D. L., "Report on Scouting Study on Precipitation of Strontium, Plutonium, and Americium from Hanford Complexant Concentrate Waste, Westinghouse Hanford Company, WHC-SD-WM-DTR-040, September 5, 1995.

${ }^{2}$ Nash, C. A., Rosencrance, S. W., Wilmarth, W. R., and Walker, B. W., "Investigation of Varied Strontium-Transuranic Precipitation Chemistries for Crossflow Filtration," BNF-003-98-0171, Rev. 0, April 19, 2000.

${ }^{3}$ Hallen, R. T., Brooks, K. P., Jagoda, L. K., "Demonstration of Entrained Solids and Sr/TRU Removal Processes with Archived AN-107 Waste," Pacific Northwest National Laboratories, BNFL-RPT-026, PNWD-3033, July, 2000.

${ }^{4}$ Nash, C. A., Rosencrance, S. W., Wilmarth, B. R., "Entrained Solids, StrontiumTransuranic Precipitation, and Crossflow Filtration of AN102 Small C," Savannah River Technology Center, BNF-003-98-218, June 12, 2000.

${ }^{5}$ Wilmarth, W. R., Nash, C. A., Eibling, R. E., Edwards, T. B., Rosencrance, S. W., "Task Technical and Quality Assurance Plan for Sr/TRU Precipitation of Hanford High Level Waste," BNF-98-003-0012, rev. 3, June 11, 1999.

6 Townson, P.S., "TWRS-P Contract No DE-AC06-96RL13308-W375, Dr/TRU Precipitation and Ultra Filtration Test Specification," Reference No. 1389, Jan. 22, 1999. 
${ }^{7}$ Hay, M. S., Bronikowski, M. G., Hsu, C. W., White, T. L., "Chemical Characterization of an Envelope C Sample from Hanford Tank 241-AN-102," Savannah River Technology Center, BNF-98-003-0250, July 31, 2000.

${ }^{8}$ Bostick, D. T., Arnold, W. D., Burgess, M. W., "Strontium Removal from Caustic Carbonate Waste Solutions using Carrier Coprecipitation," Waste Management '94 conference, Tucson, AZ, February 27-March 3, 1994.

${ }^{9}$ Herting, D. L., "Report of Scouting Study on Precipitation of Strontium, Plutonium, and Americium from Hanford Complexant Concentrate Waste," Pacific Northwest National Laboratories, WHC-SD-WM-DTR-040, September 5, 1995.

${ }^{10}$ Nash, C. A., Rosencrance, S. W., Walker, B. W., Wilmarth, B. R., op. cit., April 19, 2000 .

${ }^{11}$ Hallen, R. T., Brooks, K. P., Jagoda, L. K., op. cit., July, 2000.

${ }^{12}$ Campbell, J. A., Clauss, S. A., Grant, K. E., Hoopes, V., Mong, G. M., Steele, R., Bellofatto, D., Sharma, A., "Organic Analysis Progress Report FY 1997", PNNL11738, April 1998, Pacific Northwest National Laboratory, Richland, WA.

${ }^{13}$ Rollosson, D.I., Amato, L.C., Hulse, N.L., Wilmarth, S.R., "Tank Characterization Report for Double-Shell Tank 241-AN-102",HNF-SD-WM-ER-545, Rev. 2, July 1999.

${ }^{14}$ Hay, M. S., Bronikowski, M. G., Hsu, C. W., White, T. Lop. cit., 2000.

${ }^{15}$ Rosencrance, S. W., Dewberry, R.A., DiPrete, D. P., Edwards, T. B., Emory, S. J., Nash, C. A., Smith, S. C., Wilmarth, W. R., "Precipitation Results for AN-102: A Statistically Designed Approach to Evaluate Filterability and Sr/TRU Decontamination", BNF-003-98-0161, September, 1999.

${ }^{16}$ Prather, M. C., and C. A. Nash, BNFL Cells Filter Unit Drawings, SRS Numbers EES22561-R4-001 to EES-22561-R4-006 (six drawings), August, 1999

${ }^{17}$ Nash, C. A., Procedure for the Operation of the Shielded Cells Unit Filter (U), L12.1 procedure IWT-OP-088, rev. 3, July 21, 1997.

${ }^{18}$ Laboratory notebook WSRC-NB-96-741, issued to C. A. Nash, pp. 122 to 142.

19 King, W. D., Hassan, N. M., McCabe, D. J., "Intermediate-Scale Ion Exchange Removal of Cesium and Technetium from Hanford Tank 241-AN-102", WSRC-TR2000-00420, SRT-RPP-2000-00014, BNF-003-98-0244, December 6, 2000.

${ }^{20}$ Hay, M. S., Bronikowski, M. G., Hsu, C. W., White, T. Lop. cit., 2000. 
${ }^{21}$ Nash, C. A., Rosencrance, S. W., Wilmarth, B. R., op. cit., June 12, 2000.

${ }^{22}$ Nash, C. A., "Cells Unit Filter Operation Using Active Hanford Samples AN102 and AZ102," BNF-003-98-0113, pg. 5, July 12, 1999.

${ }^{23}$ Nash, C. A., Rosencrance, S. W., Wilmarth, B. R., op. cit., June 12, 2000.

${ }^{24}$ Duignan, M. R., "Final Report: Pilot-scale Cross-flow Ultrafiltration Test Using a Hanford Site Tank 241-AN-107 Waste Simulant - Envelope C + Entrained Solids + Strontium-Transuranic Precipitation," Savannah River Technology Center, BNF-00398-0226, March 24, 2000.

${ }^{25}$ Nash, C. A., Rosencrance, S. W., Walker, B. W., Wilmarth, B. R., op. cit.., April 18, 2000 .

${ }^{26}$ Hallen, R. T., Brooks, K. P., Jagoda, L. K., op. cit., July, 2000.

${ }^{27}$ Duignan, M. R., op. cit., March 24, 2000.

${ }^{28}$ Rosencrance, S. W., op. cit., September, 1999.

${ }^{29}$ Rosencrance, S. W., King, W. D., Nash, C. A., "Physical Characterization for Hanford Tank Waste Samples AN-102, AN-103, and AZ-102", WSRC-TR-2000-00026, SRTRPP-2000-00352, January, 2001. 


\section{APPENDIX A}

\section{SAMPLE AND ANALYSIS PLAN AND BATCH VOLUME ESTIMATES}

Basic information on the sample bottles, estimated sample and batch volume, and analysis tables is listed in this appendix. Volumes were estimated beforehand and do not necessarily match the campaign exactly. The following analyses were used in the program:

- ICP-ES: Inductively-Coupled Plasma Emission Spectroscopy provides over a dozen elements, mostly metals.

- AA(element): Atomic Absorption measures (element) concentration.

- Gamma: Gamma counting measures Cs-137, Eu-154, Eu-155, Co-60.

- $\quad$ Sr-90 was measured by a counting method.

- Am-241, plutonium, and curium were measured by a TTA counting technique. A related series of procedures for the same sample provides these.

- ISE: Ion selective electrode for $\mathrm{Cl}, \mathrm{F}$

- IC Anions: Ion Chromatography for common anions

- Tc-99 was measured by Inductively-Coupled Plasma Mass Spectroscopy.

- Uranium was measured by a wet chemical method commonly called "Chemcheck".

- Weight percents were measured with standard filtration, drying, and weighing methods.

A "lollipop" is a shielded sample bottle. The shielding is of at least half an inch plastic that is effective in reducing alpha-beta dosage to extremities. 


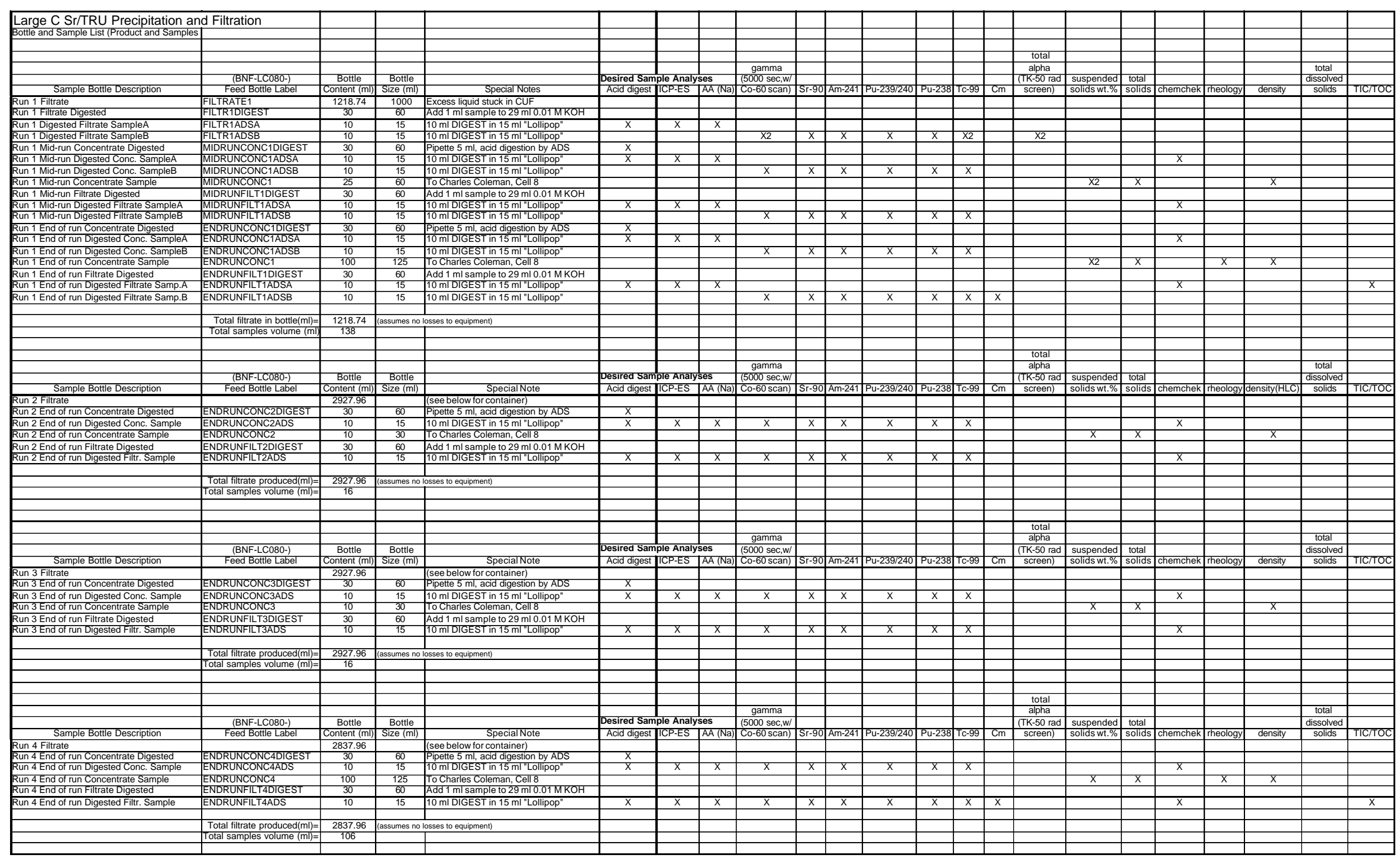




\begin{tabular}{|c|c|c|c|c|c|c|c|c|c|c|c|c|c|c|c|c|c|c|c|c|c|c|}
\hline Sample BC $\mathrm{BC}$ & $\begin{array}{l}\text { (BNF-LCO80-) } \\
\text { Feed Bottle Label }\end{array}$ & $\begin{array}{l}\text { Bottle } \\
\text { Content (mil) }\end{array}$ & \begin{tabular}{|l|} 
Bottle \\
Size $(\mathrm{mll})$ \\
\end{tabular} & & \begin{tabular}{|l} 
|Desired Sam \\
Acid digest \\
\end{tabular} & $\begin{array}{l}\text { pleAnaly } \\
\text { plicP-ES }\end{array}$ & $\begin{array}{l}\text { ses } \\
\text { AA(Na) } \\
\end{array}$ & \begin{tabular}{|l}
$\frac{(5000 \mathrm{sec}, \mathrm{W} /}{(00-60 \text { scan }}$ \\
\end{tabular} & Sr-90 & Am-241 & Pu-239/240 & Pu-238 & c-99 & $\mathrm{cm}$ & \begin{tabular}{|l|l|} 
T(TK-50 rad \\
screen $)$ \\
\end{tabular} & $\begin{array}{l}\text { suspended } \\
\text { solids wi:\% } \\
\end{array}$ & \begin{tabular}{|l|} 
total \\
Solids \\
\end{tabular} & nemchek & freolog & density & $\begin{array}{l}\frac{\text { dissolved }^{-}}{\text {solids }} \\
\end{array}$ & ताC/TOC \\
\hline Run 5 Filtrate & & 2927.96 & & 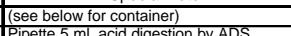 & & & & & & & & & & & & & & & & & & \\
\hline 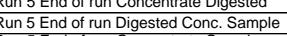 & 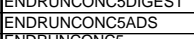 & $\frac{30}{10}$ & \begin{tabular}{|l|l|}
60 \\
15 \\
\end{tabular} & 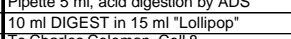 & \begin{tabular}{|c|c}
$x$ \\
$x$
\end{tabular} & $x$ & $x$ & $x$ & $\mathrm{x}$ & $\mathrm{x}$ & $\mathrm{x}$ & $x$ & $x$ & & & & $\sqrt{5}+5$ & $x$ & & & & \\
\hline 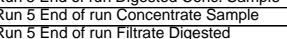 & $\begin{array}{l}\text { ENDRUNCONCS } \\
\text { ENDRUNFILITDIGEST }\end{array}$ & $\frac{10}{30}$ & $\frac{30}{60}$ & 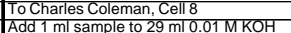 & & & & & & & & & & & & $x$ & $x$ & & & $x$ & & \\
\hline \multirow{6}{*}{ Run 5 End of run Digested Filtr. Sample } & ENDRUNFILT TADS & $\frac{50}{10}$ & 15 & 10 m DIGEST in $15 \mathrm{ml}$ " LOllipop" & $x$ & $x$ & $x$ & $x$ & $x$ & $x$ & $x$ & $x$ & $x$ & & & & & $x$ & & & & \\
\hline & Total filtrate produced(m) $=$ & $\begin{array}{ll}2927.96 \\
\end{array}$ & aassumes no & losses to equipment) & & & & & & & & & & & & & & & & & & \\
\hline & Total samples volume $(\mathrm{ml})=$ & & & & & & & & 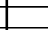 & & & & & & & & & & & & & \\
\hline & & & & & & & & & + & & & & + & & & & & & & & & \\
\hline & & & & & & & & sammas & & & & & & & total & & & & & & total & \\
\hline & \begin{tabular}{|l} 
(BNF-LCO80-) \\
\end{tabular} & Bottle & Bottle & & DesiredSam & $\frac{1}{\text { nple Analy }}$ & ises & $\frac{15000 \mathrm{sec}, \mathrm{w} / \mathrm{t}}{5}$ & & & & & & & 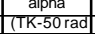 & susperined & total & & & & Itissolved & \\
\hline Sample Bottle Description & Feed Bottle Label & Content (mI) & Size (m) & Specialnote & \begin{tabular}{|l|} 
Acid digest \\
\end{tabular} & IICP-ES & $\mathrm{AA}(\mathrm{Na})$ & (Co-60 scan) & ST-90 & Am-241 & Pu-239/240 & Pu-238 & $3 \mid c-99$ & $\mathrm{~cm}$ & screen) & solids w.\% & Solids & chemchek & heolor & density & solids & ICT/C \\
\hline 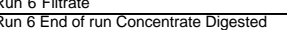 & ENDRU & 2927.96 & 60 & $\begin{array}{l}\text { (sisee below for contalaner) } \\
\text { Piipette } 5 \mathrm{ml} \text {, acid digestion by ADS }\end{array}$ & & & & & & & & & & & & & & & & & & \\
\hline uun 6 End of run Digested Conc. Sample & ENDRUNCONCGADS & $\frac{30}{10}$ & 15 & 10 mI DIGEST in 15 ml "Lollipop" & $\hat{x}$ & $x$ & $x$ & $x$ & $x$ & $x$ & $\mathrm{x}$ & $x$ & $x+1$ & & & & & $x$ & & & & \\
\hline 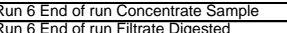 & ENDRUNCONC6 & $\frac{10}{30}$ & $\frac{30}{60}$ & $\begin{array}{l}\text { To Charles Coleman, Cell } 8 \\
\text { Add } 1 \mathrm{ml} \text { sample to } 29 \mathrm{ml0} \text {.01 } \mathrm{MKOH}\end{array}$ & & & & & & & & & & & & $x$ & $x$ & & & $x$ & & \\
\hline \multirow[t]{6}{*}{ Run 6 End of run Digested Filtr. Sample } & ENDRUNFILTGADS & 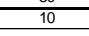 & 15 & 10 ml DIGEST in $15 \mathrm{ml}$ " "Lollipop" & $x$ & $x$ & $x$ & $x$ & $x$ & $x$ & $x$ & $x$ & $x$ & & & & & $x$ & & & & \\
\hline & Total filtrate produced(m) & 2927.96 & aassumes no & losses to equipment) & & & & & 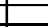 & & & & 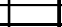 & & & & & & & & & \\
\hline & Total samples volume $(\mathrm{m})=$ & 16 & & & & & & & $-5+2>$ & & & & & & & & & & & & & \\
\hline & & & & & & & & & $\Gamma+5+2$ & & & & & & & & & & & & & \\
\hline & & & & & & & & gamma & & & & & & & alpha & & & & & & total & \\
\hline & (BNF-LCWOBO-) & Bottle & 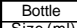 & & DesiredSam & ple Analy & ses & $(5000 \mathrm{sec}, \mathrm{w} t$ & & & & & & & $\mid$ (TK-50 rad & suspended & total | & & & & dissolved & \\
\hline $\begin{array}{l}\text { Sample Bottle Description } \\
\text { Sun } 7 \text { Fitrate }\end{array}$ & \begin{tabular}{|l|l|} 
Feed Bottle Label \\
\end{tabular} & $\begin{array}{l}\frac{C}{C} \text { Content (m) } \\
2837.96\end{array}$ & Size $(\mathrm{ml})$ & | & Acid digest & |CICP-ES & AA(Na) & Co-60 scan) & Sr-90 & Am-241 & Pu-239/240 & Pu-238 & Tc-99 & $\mathrm{cm}$ & screen) & solids wt.\% & 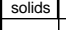 & chemchek & heology & density & solids & TI/TOC \\
\hline Run 7 End of run Concentrate Digested & ENDRUNCONCTDIGEST & 30 & 60 & Pipette 5 ml, acid digestion by ADS & $x$ & 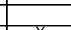 & 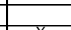 & $\sqrt{5}+2>$ & 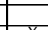 & 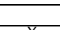 & $\sqrt{5}+2>$ & 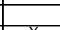 & - & & & & & 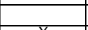 & & & & \\
\hline $\begin{array}{l}\text { ed Conc. Sample } \\
\text { ntrate Sample }\end{array}$ & \begin{tabular}{|l|} 
ENDDUNCONC7AS \\
ENDRUNCONC7
\end{tabular} & $\frac{10}{100}$ & $\frac{15}{125}$ & $\begin{array}{l}10 \mathrm{mlDT} \\
10 \text { Chart }\end{array}$ & $x$ & $x$ & $x$ & $x$ & $x$ & $x$ & $x$ & $x$ & $x$ & & & $\bar{x},+3$ & $x$ & $x$ & $x$ & $\bar{x}+2+$ & & \\
\hline jun 7 End of run Filtrate Digested & ENDRUNFILTTDIGEST & 30 & 60 & Add $1 \mathrm{ml}$ sample & & & & & & & & & & & & & $x$ & & & & & \\
\hline \multirow[t]{3}{*}{$\begin{array}{l}\text { Run } 7 \text { End of run Digested Filtr. Sample } \\
\end{array}$} & ENDRUNFILTAADS & 10 & $\frac{15}{15}$ & f 10 ml DIGEST i in 15 ml "Lollipop" & $x$ & $x$ & $x$ & $x$ & $x$ & $x$ & $\bar{x}$ & $x$ & $x$ & $\mathrm{x}$ & & & & $x$ & & & & $x$ \\
\hline & Total filtrate produced(m) & $\begin{array}{l}2837.96 \\
106\end{array}$ & aassumes no & losses to equipment) & & & & & & & & & & & & & & & & & & \\
\hline & & & & & & & & & & & & & & & & & & & & & & \\
\hline
\end{tabular}


WSRC-TR-2000-00506

\begin{tabular}{|c|c|c|c|c|c|c|c|c|c|c|c|c|c|c|c|c|c|c|c|c|c|}
\hline & $\begin{array}{l}\text { (BNF-LC080-) } \\
\text { Feed Bottle Label }\end{array}$ & $\begin{array}{l}\text { Bottle } \\
\text { Content(ml }\end{array}$ & $\begin{array}{l}\text { Bottle } \\
\text { Size (mll) }\end{array}$ & & \begin{tabular}{|l|} 
Desired Sa \\
Aciddiges \\
\end{tabular} & 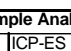 & $\begin{array}{l}\text { Iyses } \\
\text { AA (Na) }\end{array}$ & $\mid \begin{array}{l}(5000 \text { sec,wl } \\
\text { (co-60 scan })\end{array}$ & $|S r-90|$ & $\mid$ Am-241 & Pu-239/240 & Pu-238 & Tc-99 & $\mathrm{cm}$ & \begin{tabular}{|c|} 
TK-50 rad \\
screen)
\end{tabular} & \begin{tabular}{|l|} 
suspended \\
solids wt.\% \\
\end{tabular} & \begin{tabular}{|l|} 
total \\
solids \\
\end{tabular} & chemchek & & density & $\begin{array}{l}\text { dissolved } \\
\text { solids }\end{array}$ \\
\hline $\begin{array}{l}\text { Sample Bomle Uescinfirion } \\
\text { Used NaOH, Wash Volume } 1\end{array}$ & & $\frac{60}{600}$ & $\frac{S z e(\min )}{1000}$ & & & & & & & & Pu-239/240 & & & & & & & & & density & \\
\hline Used NaOH, Wash Vol. 1 Digested \#1 & WASH1DIGEST1 & 30 & 60 & Add $1 \mathrm{ml}$ sample to $29 \mathrm{ml} 0.01 \mathrm{M} \mathrm{KOH}$ & & & & & & & & & & & & & & & & & \\
\hline Used NaOH Digested, Wash Vol. 1 Samp\#1 & & 10 & 15 & & $\bar{x}$ & $\mathrm{X}$ & $\mathrm{X}$ & $\mathrm{x}$ & $\mathrm{x}$ & $\mathrm{X}$ & $\bar{x}$ & $\mathrm{X}$ & & & & & & & & & \\
\hline Used NaOH, Wash Vol. 1 Digested \#2 & WASH1DIGEST2 & 30 & 60 & Add $1 \mathrm{ml}$ sample to $29 \mathrm{ml} 0.01 \mathrm{M} \mathrm{KOH}$ & & & & & & & & & & & & & & & & & \\
\hline Used NaOH Digested, Wash Vol. 1 Samp\#2 & $\begin{array}{l}\text { WASH1ADS2 } \\
\text { WASHSAMP }\end{array}$ & $\frac{10}{25}$ & $\frac{15}{30}$ & 10 mI DIGEST in $15 \mathrm{ml}$ "Lollipop" & $x$ & $x$ & $x$ & $\mathrm{x}$ & $x$ & $x$ & $x$ & $\mathrm{x}$ & & & & & & & & & \\
\hline \begin{tabular}{|l} 
Used NaOH, Wash Vol. 1 Sample \\
Used NaOH, Wash Volume 2
\end{tabular} & $\begin{array}{l}\text { WASHSAMP } \\
\text { WASH2 }\end{array}$ & $\frac{25}{600}$ & $\frac{30}{1000}$ & Sample at end of run & & & & & & & & & & & & & & & & & $\bar{x}$ \\
\hline Used NaOH, Wash Vol. 2 Digested \#1 & WASH2DIGEST1 & 30 & 60 & Add $1 \mathrm{ml}$ sample to $29 \mathrm{ml} 0.01 \mathrm{M} \mathrm{KOH}$ & & & & & & & & & & & & & & & & & \\
\hline Used NaOH Digested, Wash Vol. 2 Samp\#1 & WASH2ADS1 & 10 & 15 & 10 mI DIGEST in $15 \mathrm{ml}$ " "Lollipop" & $\bar{x}$ & $\mathrm{x}$ & $\mathrm{x}$ & $\mathrm{x}$ & $\mathrm{x}$ & $x$ & $\bar{x}$ & $x$ & & & & & & & & & \\
\hline & WASH2DIGEST2 & 30 & 60 & Add $1 \mathrm{ml}$ sample to $29 \mathrm{ml} 0.01 \mathrm{M} \mathrm{KOH}$ & & & & & & & & & & & & & & & & & \\
\hline Used NaOH Digested, Wash Vol. 2 Samp\#2 & $\begin{array}{l}\text { WASH2ADS2 } \\
\text { WASTSAMP }\end{array}$ & $\frac{10}{25}$ & 15 & $10 \mathrm{ml}$ DIGEST in $15 \mathrm{ml}$ "Lollipop" & $x$ & $\mathrm{x}$ & $x$ & $x$ & $x$ & $\mathrm{x}$ & $\mathrm{x}$ & $\mathrm{x}$ & & & & & & & & & $\overline{7} \times$ \\
\hline $\begin{array}{l}\text { Used NaOH, Wash Vol. } 2 \text { Sample } \\
\text { Used NaOH, Wash Volume } 3\end{array}$ & $\begin{array}{l}\text { WASHESAMP } \\
\text { WASH }\end{array}$ & $\frac{25}{600}$ & $\frac{30}{1000}$ & Sample at end of run & & & & & & & & & & & & & & & & & $x$ \\
\hline Used $\mathrm{NaOH}$, Wash Vol. 3 Digested \#1 & WASH3DIGEST1 & 30 & 60 & Add $1 \mathrm{ml}$ sample to $29 \mathrm{ml} 0.01 \mathrm{M} \mathrm{KOH}$ & & & & & & & & & & & & & & & & & \\
\hline Used NaOH Digested, Wash Vol. 3 Samp\#1 & WASH3ADS1 & $\frac{10}{30}$ & 15 & 10 mI DIGEST in $15 \mathrm{ml}$ " Lollipop" & $x$ & $\mathrm{x}$ & $\mathrm{x}$ & $\mathrm{x}$ & $\mathrm{x}$ & $\mathrm{x}$ & $\mathrm{x}$ & $\mathrm{X}$ & & & & & & & & & \\
\hline Used NaOH, Wash Vol. 3 Digested \#2 & WASH3DIGEST2 & & 60 & Add $1 \mathrm{ml}$ sample to $29 \mathrm{ml} 0.01 \mathrm{M} \mathrm{KOH}$ & & & & & & & & & & & & & & & & & \\
\hline Used NaOH Digested, Wash Vol. 3 Samp\#2 & WASH3ADS2 & $\frac{10}{25}$ & $\frac{15}{30}$ & $10 \mathrm{ml}$ DIGEST in $15 \mathrm{ml}$ "Lollipop" & $\mathrm{x}$ & $\mathrm{x}$ & $x$ & $\mathrm{x}$ & $x$ & $\mathrm{x}$ & $\mathrm{X}$ & $x$ & & & & & & & & & $\bar{x},{ }^{2}$ \\
\hline $\begin{array}{l}\text { Used NaOH, Wash Vol. } 3 \text { Sample } \\
\text { Used NaOH, Wash Volume } 4\end{array}$ & $\begin{array}{l}\text { WASSBSAMP } \\
\text { WASH4 }\end{array}$ & $\frac{25}{600}$ & $\frac{30}{1000}$ & Sample at end of run & & & & & & & & & & & & & & & & & \\
\hline Used NaOH, Wash Vol. 4 Digested \#1 & WASH4DIGEST1 & 30 & $\frac{100}{60}$ & Add $1 \mathrm{ml}$ sample to $29 \mathrm{ml} 0.01 \mathrm{M} \mathrm{KOH}$ & & & & & & & & & & & & & & & & & \\
\hline Used NaOH Digested, Wash Vol. 4 Samp\#1 & WASHAADS & 10 & 15 & $10 \mathrm{ml} \mathrm{DIGEST} \mathrm{in} 15 \mathrm{ml}$ "Lollipp & 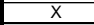 & $x$ & $x$ & $x$ & $x$ & $x$ & 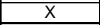 & $x$ & & & & & & & & & \\
\hline Used NaOH, Wash Vol. 4 Digested \#2 & WASH4DIGEST2 & 30 & 60 & Add $1 \mathrm{ml}$ sample to $29 \mathrm{ml} 0.01 \mathrm{M} \mathrm{KOH}$ & & & & & & & & & & & & & & & & & \\
\hline Used NaOH Digested, Wash Vol. 4 Samp\#2 & $\begin{array}{l}\text { WASH4ADS2 } \\
\text { WAS4SAMP }\end{array}$ & $\frac{10}{25}$ & $\frac{15}{30}$ & 10 mI DIGEST' in $15 \mathrm{ml}$ "Lollipop" & $\mathrm{X}$ & $\mathrm{x}$ & $x$ & $\bar{x}$ & $x$ & $\mathrm{x}$ & $\mathrm{X}$ & $x$ & & & & & & & & & \\
\hline $\begin{array}{l}\text { Weash Concentrate, Wash Vol. } 1 \text { Digested\#1 } \\
\text { Walle }\end{array}$ & WASHCONC1DIGEST1 & 30 & 60 & $\begin{array}{l}\text { Pipette } 5 \mathrm{ml} \text {, acid digestion by ADS } \\
\text { Pand }\end{array}$ & $\mathrm{x}$ & & & & & & & & & & & & & & & & \\
\hline Digested Wash Conc., Vol. 1 Sample \#1 & WASHCONC1ADS1 & 10 & 15 & 10 ml DIGEST in 15 ml "Lollipop" & $\mathrm{X}$ & $\mathrm{X}$ & $\mathrm{X}$ & $\mathrm{X}$ & $\mathrm{x}$ & $\mathrm{X}$ & $\mathrm{X}$ & $\mathrm{X}$ & & & & & & $x$ & & & \\
\hline Wash Concentrate, Wash Vol. 1 Digested\#2 & WASHCONC1DIGEST2 & 30 & 60 & Pipette $5 \mathrm{ml}$, acid digestion by ADS & $\mathrm{X}$ & & & & & & & & & & & & & & & & \\
\hline Digested Wash Conc., Vol. 1 Sample \#2 & WASHCONC1 & 10 & 15 & $10 \mathrm{ml}$ DIGEST in $15 \mathrm{ml}$ "Lollipop" & $x$ & $x$ & $x$ & $x$ & $x$ & $x$ & $x$ & $x$ & & & & ר & Y) & $x$ & & קo & \\
\hline \begin{tabular}{|l} 
Wash Concentrate Sample, Wash Vol. 1 \\
Wash Concentrate, Wash Vol. 2 Digested\#1
\end{tabular} & $\begin{array}{l}\text { WASHCONC1SAMP } \\
\text { WASHCONC2DIGEST1 }\end{array}$ & $\frac{10}{30}$ & $\begin{array}{r}30 \\
60\end{array}$ & $\begin{array}{l}\text { To Charles Coleman, Cell } 8 \\
\text { Pipette } 5 \text { ml, acid digestion by ADS }\end{array}$ & $\bar{x}$ & & & & & & & & & & & $x_{2}$ & $x_{2}$ & & & $x_{2}$ & \\
\hline Digested Wash Conc.. Vol. 2 Sample \#1 & WASHCONC2ADS1 & 10 & 15 & 10 ml DIGEST in 15 ml "Lollipop" & $\bar{x}$ & $x$ & $x$ & $\mathrm{x}$ & $\mathrm{x}$ & $\mathrm{x}$ & $\mathrm{X}$ & $\mathrm{X}$ & & & & & & $\bar{x}$ & & & \\
\hline Wash Concentrate, Wash Vol. 2 Digested\#2 & WASHCONC2DIGEST2 & 30 & 60 & acid digestion by ADS & $\mathrm{X}$ & & & & & & & & & & & & & & & & \\
\hline Digested Wash Conc., Vol. 2 Sample \#2 & WASHCONC2ADS2 & 10 & 15 & 10 ml DIGEST in $15 \mathrm{ml}$ "Lollip & $x$ & $x$ & $x$ & $\bar{x}$ & $\mathrm{x}$ & $x$ & $x$ & $x$ & & & & & & $x$ & & & \\
\hline Wash Concentrate Sample, Wash Vol. 2 & WASHCONC2SAMP & 10 & 30 & To Charles Coleman, Cell 8 & & & & & & & & & & & & $\times 2$ & $x_{2}$ & & & $x 2$ & \\
\hline \begin{tabular}{|l} 
Wash Concentrate, Wash Vol. 3 Digested\#1 \\
Digested Wash Conc. Vol. 3 Sample \#1
\end{tabular} & WASHCONCBDIGEST1 & $\frac{30}{10}$ & $\frac{60}{15}$ & $\begin{array}{l}\text { Pipette } 5 \mathrm{ml} \text {, acid digestion by ADS } \\
10 \mathrm{mI} \mid \mathrm{IIGEST} \text { in } 15 \mathrm{ml} \text { "olliopop" }\end{array}$ & $\frac{x}{x}$ & $x$ & $x$ & 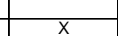 & $x$ & $x$ & $x$ & $x$ & & & & & & $x$ & & & \\
\hline Wash Concentrate, Wash Vol. 3 Digested\#2 & WASHCONC3DIGEST2 & 30 & 60 & Pipette $5 \mathrm{ml}$, acid digestion by ADS & $x$ & & & & & & & & & & & & & & & & \\
\hline Digested Wash Conc., Vol. 3 Sample \#2 & WASHCONC3ADS2 & 10 & 15 & 10 mI DIGEST in 15 ml "Lollipop" & $x$ & $\mathrm{x}$ & $x$ & $\mathrm{X}$ & $\mathrm{x}$ & $\mathrm{x}$ & $x$ & $\mathrm{x}$ & & & & & & $\bar{x}$ & & & \\
\hline Wash Concentrate Sample, Wash Vol. 3 & WASHCONC & 10 & 30 & To Charles C & & & & & & & & & & & & $x_{2}$ & $\mathrm{X} 2$ & & & $\underline{x 2}$ & \\
\hline Wash Concentrate, Wash Vol. 4 Digested\#1 & WASHCONC4DIGEST1 & 30 & 60 & $\begin{array}{l}\text { Pipette } 5 \mathrm{ml} \text {, acid digestion by ADS } \\
\text { Apent }\end{array}$ & $\frac{x}{x}$ & $x$ & $x$ & $x$ & $x$ & $x$ & $x$ & $x$ & & & & & & $\bar{x}$ & & & \\
\hline \begin{tabular}{|l} 
Digested Wash Conc., Vol. 4 Sample \#1 \\
Whash Concentrate Wash Wol L Digested\#2
\end{tabular} & WASHCONC4ADS1 & $\frac{10}{30}$ & 15 & $10 \mathrm{ml}$ DIGEST in $15 \mathrm{ml}$ "Lollipop" & $\frac{x}{x}$ & $\mathrm{x}$ & $x$ & $x$ & $\mathrm{x}$ & $x$ & $x$ & $x$ & & & & & & $x$ & & & \\
\hline $\begin{array}{l}\text { Wash Concentrate, Wash Vol. } 4 \text { D Digested\#2 } \\
\text { Digested Wash Conc., Vol. } 4 \text { Sample \#2 }\end{array}$ & $\frac{1}{\text { WAASHCONC }}$ & $\frac{30}{10}$ & $\frac{60}{15}$ & 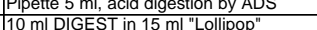 & $\frac{x}{x}$ & $x$ & $x$ & $\mathrm{x}$ & $x$ & $x$ & $\mathrm{x}$ & $x$ & & & & & & $\bar{x}$ & & & \\
\hline Wash Concentrate Sample, Wash Vol. 4 & WASI & 10 & 30 & To Charles Coleman, Cell 8 & & & & & & & & & & & & $\mathrm{X} 2$ & $x_{2}$ & & & $\underline{x 2}$ & \\
\hline End of Project Concentr & HIGHCONC1 & $? ? ?$ & 1000 & & & & & & & & & & & & & & & & & & \\
\hline End of Project Concentrate, Bott & $\mathrm{HIGHCONC}$ & & 1000 & & & & & & & & & & & & & & & & & & \\
\hline
\end{tabular}


WSRC-TR-2000-00506

\begin{tabular}{|c|c|c|c|c|c|c|c|c|c|c|c|c|c|}
\hline & (BNF-LC080-) & Bottle & Bottle & & Desired San & nple Ana & yses & $(5000 \mathrm{sec}, \mathrm{w} /$ & & & & & \\
\hline Sample Bottle Description & Feed Bottle Label & Content (ml & Size $(\mathrm{ml}$ & Special Note & $\begin{array}{l}\text { Acid digest } \\
\end{array}$ & ICP-ES & $\mathrm{AA}(\mathrm{Na}$ & (oo-60 scan) & Sr-90 & Am-241 & Pu-239/240 & Pu-238 & \\
\hline Filtrate, Bottle 2 & FILTRATE2 & 1700 & 2000 & Graduated, baled top and bottom & & & & & & & & & \\
\hline Filtrate, Bottle 2 (Digested) & FILTRATE2DIGEST & 30 & 60 & Add $1 \mathrm{ml} \mathrm{sample} \mathrm{to} 29 \mathrm{ml} 0.01 \mathrm{M} \mathrm{KOH}$ & & & & & & & & & \\
\hline Digested Filtrate Sample, Bottle 2 & $\begin{array}{l}\text { FILTRATE2ADS } \\
\end{array}$ & 10 & 15 & $10 \mathrm{ml}$ DIGEST in $15 \mathrm{ml}$ "Lollipop" & $\mathrm{x}$ & $\mathrm{X}$ & $\mathrm{x}$ & $\mathrm{X} 2$ & $\mathrm{x}$ & $\mathrm{x}$ & $\mathrm{x}$ & $\mathrm{x}$ & $\mathrm{x} 2$ \\
\hline Filtrate, Bottle 3 & FILTRATE3 & 1700 & 2000 & Graduated, baled top and bottom & & & & & & & & & \\
\hline Filtrate, Bottle 3 (Digested) & FILTRATE3DIGEST & 30 & 60 & Add $1 \mathrm{ml} \mathrm{sample}$ to $29 \mathrm{ml} 0.01 \mathrm{M} \mathrm{KOH}$ & & & & & & & & & \\
\hline Digested Filtrate Sample, Bottle 3 & FILTRATE3ADS & 10 & 15 & $10 \mathrm{ml}$ DIGEST in $15 \mathrm{ml}$ "Lollipop" & $\mathrm{x}$ & $\mathrm{x}$ & $\mathrm{x}$ & $\mathrm{X} 2$ & $\mathrm{x}$ & $\mathrm{x}$ & $\mathrm{x}$ & $\mathrm{x}$ & $\mathrm{X} 2$ \\
\hline Filtrate, Bottle 4 & FILTRATE4 & 1700 & 2000 & Graduated, baled top and bottom & & & & & & & & & \\
\hline Filtrate, Bottle 4 (Digested) & FILTRATE4DIGEST & 30 & 60 & Add $1 \mathrm{ml} \mathrm{sample}$ to $29 \mathrm{ml} 0.01 \mathrm{M} \mathrm{KOH}$ & & & & & & & & & \\
\hline Digested Filtrate Sample, Bottle 4 & FILTRATE4ADS & 10 & 15 & $10 \mathrm{ml}$ DIGEST in $15 \mathrm{ml}$ "Lollipop" & $\mathrm{x}$ & $\mathrm{x}$ & $\mathrm{x}$ & $\mathrm{X} 2$ & $\mathrm{x}$ & $\mathrm{x}$ & $\mathrm{x}$ & $\mathrm{x}$ & $\mathrm{x} 2$ \\
\hline $\begin{array}{l}\text { Filtrate, Bottle } 5 \\
\end{array}$ & FILTRATE5 & 1700 & 2000 & Graduated, baled top and bottom & & & & & & & & & \\
\hline Filtrate, Bottle 5 (Digested) & FILTRATE5DIGEST & 30 & 60 & Add $1 \mathrm{ml} \mathrm{sample} \mathrm{to} 29 \mathrm{ml} 0.01 \mathrm{M} \mathrm{KOH}$ & & & & & & & & & \\
\hline Digested Filtrate Sample, Bottle 5 & FILTRATE5ADS & 10 & 15 & $10 \mathrm{ml}$ DIGEST in $15 \mathrm{ml}$ "Lollipop" & $\mathrm{x}$ & $\mathrm{X}$ & $x$ & $\mathrm{X} 2$ & $x$ & $x$ & $\mathrm{x}$ & $\mathrm{X}$ & $\mathrm{x} 2$ \\
\hline Filtrate, Bottle 6 & FILTRATE6 & 1700 & 2000 & Graduated, baled top and bottom & & & & & & & & & \\
\hline Filtrate, Bottle 6 (Digested) & FILTRATE6DIGEST & 30 & 60 & Add $1 \mathrm{ml} \mathrm{sample} \mathrm{to} 29 \mathrm{ml} 0.01 \mathrm{M} \mathrm{KOH}$ & & & & & & & & & \\
\hline Digested Filtrate Sample, Bottle 6 & FILTRATE6ADS & 10 & 15 & $10 \mathrm{ml}$ DIGEST in $15 \mathrm{ml}$ "Lollipop" & $\mathrm{x}$ & $\mathrm{x}$ & $\mathrm{x}$ & $\mathrm{X} 2$ & $\mathrm{x}$ & $\mathrm{x}$ & $\mathrm{x}$ & $\mathrm{x}$ & $\mathrm{x} 2$ \\
\hline $\begin{array}{l}\text { Filtrate, Bottle } 7 \\
\end{array}$ & $\begin{array}{l}\text { FILTRATE7 } \\
\end{array}$ & 1700 & 2000 & Graduated, baled top and bottom & & & & & & & & & \\
\hline Filtrate, Bottle 7 (Digested) & FILTRATE7DIGEST & 30 & 60 & Add $1 \mathrm{ml} \mathrm{sample} \mathrm{to} 29 \mathrm{ml} 0.01 \mathrm{M} \mathrm{KOH}$ & & & & & & & & & \\
\hline Digested Filtrate Sample, Bottle 7 & FILTRATE7ADS & 10 & 15 & 10 ml DIGEST in $15 \mathrm{ml}$ "Lollipop" & $\mathrm{x}$ & $\mathrm{x}$ & $\mathrm{x}$ & $\mathrm{X} 2$ & $\mathrm{x}$ & $\mathrm{x}$ & $\mathrm{x}$ & $\mathrm{x}$ & $\mathrm{x} 2$ \\
\hline Filtrate, Bottle 8 & FILTRATE8 & 1700 & 2000 & Graduated, baled top and bottom & & & & & & & & & \\
\hline Filtrate, Bottle 8 (Digested) & FILTRATE8DIGEST & 30 & 60 & Add $1 \mathrm{ml} \mathrm{sample} \mathrm{to} 29 \mathrm{ml} 0.01 \mathrm{M} \mathrm{KOH}$ & & & & & & & & & \\
\hline Digested Filtrate Sample, Bottle 8 & FILTRATE8ADS & 10 & 15 & 10 ml DIGEST in $15 \mathrm{ml}$ "Lollipop" & $\mathrm{X}$ & $\mathrm{X}$ & $\mathrm{X}$ & $\mathrm{x} 2$ & $\mathrm{X}$ & $\mathrm{X}$ & $\mathrm{X}$ & $\mathrm{X}$ & $\mathrm{x} 2$ \\
\hline Filtrate, Bottle 9 & FILTRATE9 & 1700 & 2000 & Graduated, baled top and bottom & & & & & & & & & \\
\hline Filtrate, Bottle 9 (Digested) & FILTRATE9DIGEST & 30 & 60 & Add $1 \mathrm{ml} \mathrm{sample} \mathrm{to} 29 \mathrm{ml} 0.01 \mathrm{M} \mathrm{KOH}$ & & & & & & & & & \\
\hline Digested Filtrate Sample, Bottle 9 & FILTRATE9ADS & 10 & 15 & $10 \mathrm{ml}$ DIGEST in $15 \mathrm{ml}$ "Lollipop" & $\mathrm{X}$ & $\mathrm{X}$ & $\mathrm{x}$ & $\mathrm{X} 2$ & $\mathrm{X}$ & $\mathrm{X}$ & $\mathrm{x}$ & $\mathrm{x}$ & $\mathrm{X} 2$ \\
\hline Filtrate, Bottle 10 & FILTRATE10 & 1700 & 2000 & Graduated, baled top and bottom & & & & & & & & & \\
\hline Filtrate, Bottle 10 (Digested) & FILTRATE10DIGEST & 30 & 60 & Add $1 \mathrm{ml} \mathrm{sample} \mathrm{to} 29 \mathrm{ml} 0.01 \mathrm{M} \mathrm{KOH}$ & & & & & & & & & \\
\hline Digested Filtrate Sample, Bottle 10 & FILTRATE10ADS & $\frac{50}{10}$ & 15 & 10 ml DIGEST in $15 \mathrm{ml}$ "Lollipop" & $\mathrm{x}$ & $\mathrm{x}$ & $\mathrm{x}$ & $\mathrm{X} 2$ & $\mathrm{x}$ & $\mathrm{x}$ & $\mathrm{x}$ & $\mathrm{x}$ & $\mathrm{x} 2$ \\
\hline \begin{tabular}{|l} 
Filtrate, Bottle 11 \\
\end{tabular} & FILTRATE11 & 1700 & 2000 & Graduated, baled top and bottom & & & & & & & & & \\
\hline Filtrate, Bottle 11 (Digested) & FILTRATE11DIGEST & 30 & 60 & Add $1 \mathrm{ml} \mathrm{sample}$ to $29 \mathrm{ml} 0.01 \mathrm{M} \mathrm{KOH}$ & & & & & & & & & \\
\hline Digested Filtrate Sample, Bottle 11 & FILTRATE11ADS & 10 & 15 & 10 ml DIGEST in $15 \mathrm{ml}$ "Lollipop" & $x$ & $x$ & $x$ & $\mathrm{X} 2$ & $\mathrm{x}$ & $x$ & $x$ & $x$ & $\mathrm{X} 2$ \\
\hline \begin{tabular}{|l|l|l|l|l|l} 
Filtrate, Bottle 12 \\
\end{tabular} & FILTRATE12 & 1700 & 2000 & Graduated, baled top and bottom & & & & & & & & & \\
\hline Filtrate, Bottle 12 (Digested) & FILTRATE12DIGEST & 30 & 60 & Add $1 \mathrm{ml}$ sample to $29 \mathrm{ml} 0.01 \mathrm{M} \mathrm{KOH}$ & & & & & & & & & \\
\hline Digested Filtrate Sample, Bottle 12 & FILTRATE12ADS & 10 & 15 & 10 ml DIGEST in $15 \mathrm{ml}$ "Lollipop" & $\mathrm{x}$ & $\mathrm{x}$ & $\mathrm{x}$ & $\mathrm{X} 2$ & $x$ & $x$ & $\mathrm{X}$ & $\mathrm{X}$ & $\mathrm{x} 2$ \\
\hline \begin{tabular}{|l|} 
Filtrate, Bottle 13 \\
\end{tabular} & FILTRATE13 & 1700 & 2000 & Graduated, baled top and bottom & & & & & & & & & \\
\hline Filtrate, Bottle 13 (Digested) & FILTRATE13DIGEST & 30 & 60 & Add $1 \mathrm{ml}$ sample to $29 \mathrm{ml} 0.01 \mathrm{M} \mathrm{KOH}$ & & & & & & & & & \\
\hline Digested Filtrate Sample, Bottle 13 & $\begin{array}{l}\text { FILTRATE13ADS } \\
\end{array}$ & 10 & 15 & $10 \mathrm{ml}$ DIGEST in $15 \mathrm{ml}$ "Lollipop" & $\mathrm{x}$ & $\mathrm{x}$ & $\mathrm{x}$ & $\mathrm{X} 2$ & $\mathrm{x}$ & $\mathrm{x}$ & $\mathrm{x}$ & $\mathrm{x}$ & $\mathrm{x} 2$ \\
\hline
\end{tabular}





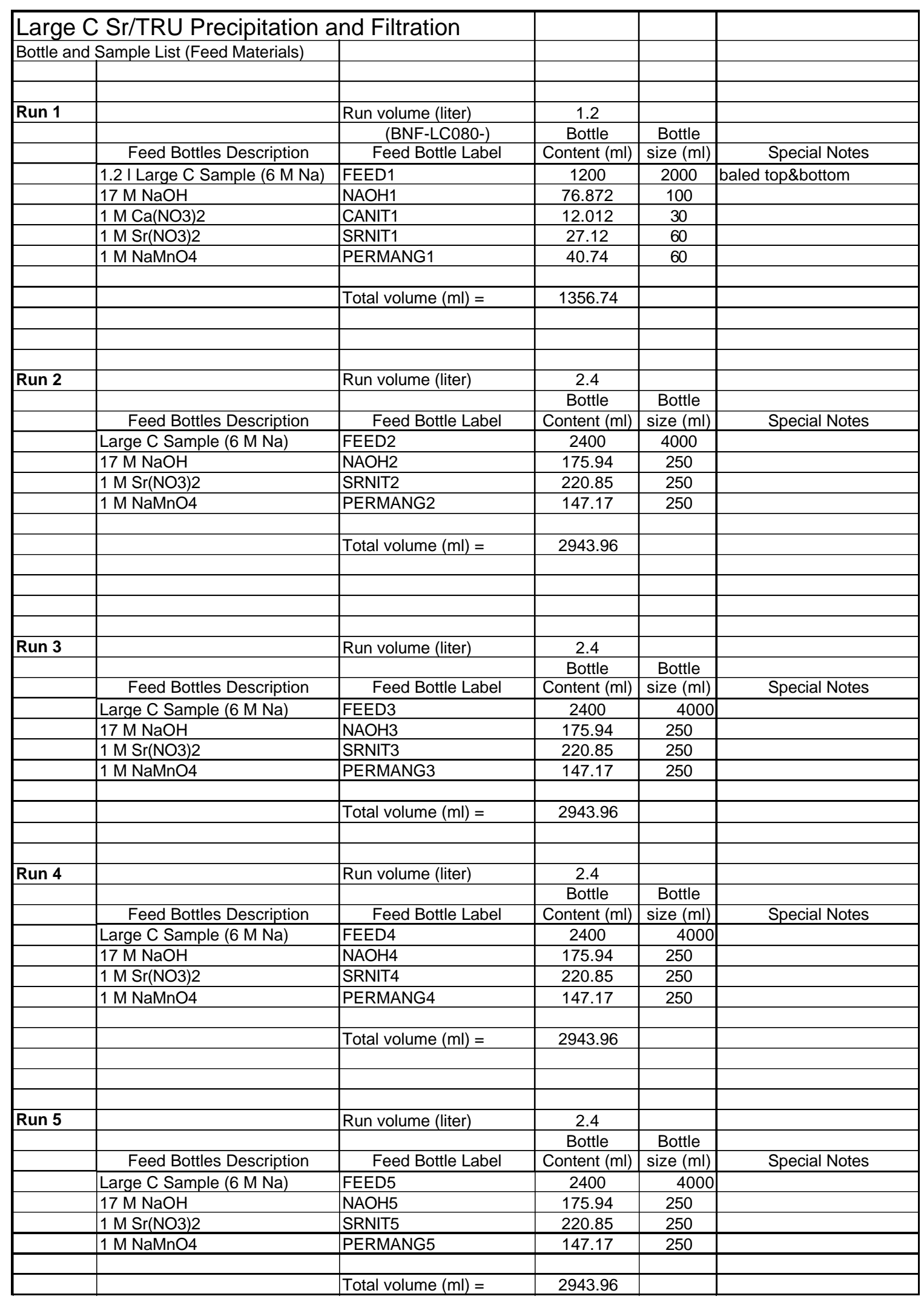




\section{Large C Precipitation and Filtration Reagent Bottle List and Volumes}

\begin{tabular}{|c|c|c|c|c|c|}
\hline Run 6 & & Run volume (liter) & 2.4 & & \\
\hline & & & Bottle & Bottle & \\
\hline & Feed Bottles Description & Feed Bottle Label & Content (ml) & size $(\mathrm{ml})$ & Special Notes \\
\hline & Large C Sample (6 M Na) & FEED6 & 2400 & 4000 & \\
\hline & $17 \mathrm{M} \mathrm{NaOH}$ & NAOH6 & 175.94 & 250 & \\
\hline & $1 \mathrm{M} \mathrm{Sr}(\mathrm{NO} 3) 2$ & SRNIT6 & 220.85 & 250 & \\
\hline & $1 \mathrm{M} \mathrm{NaMnO} 4$ & PERMANG6 & 147.17 & 250 & \\
\hline & & & & & \\
\hline & & Total volume $(\mathrm{ml})=$ & 2943.96 & & \\
\hline & & & & & \\
\hline & & & & & \\
\hline & & & & & \\
\hline & & & & & \\
\hline Run 7 & & Run volume (liter) & 2.4 & & \\
\hline & & & Bottle & Bottle & \\
\hline & Feed Bottles Description & Feed Bottle Label & Content (ml) & size $(\mathrm{ml})$ & Special Notes \\
\hline & Large C Sample (6 M Na) & FEED7 & 2400 & 4000 & \\
\hline & $17 \mathrm{M} \mathrm{NaOH}$ & $\mathrm{NAOH} 7$ & 175.94 & 250 & \\
\hline & $1 \mathrm{M} \mathrm{Sr}(\mathrm{NO} 3) 2$ & SRNIT7 & 220.85 & 250 & \\
\hline & $1 \mathrm{M} \mathrm{NaMnO} 4$ & PERMANG7 & 147.17 & 250 & \\
\hline & & & & & \\
\hline & & Total volume $(\mathrm{ml})=$ & 2943.96 & & \\
\hline & & & & & \\
\hline & & & & & \\
\hline
\end{tabular}




\section{APPENDIX B}

\section{CALCULATIONS}

\section{Calculations below were made for reagent additions}

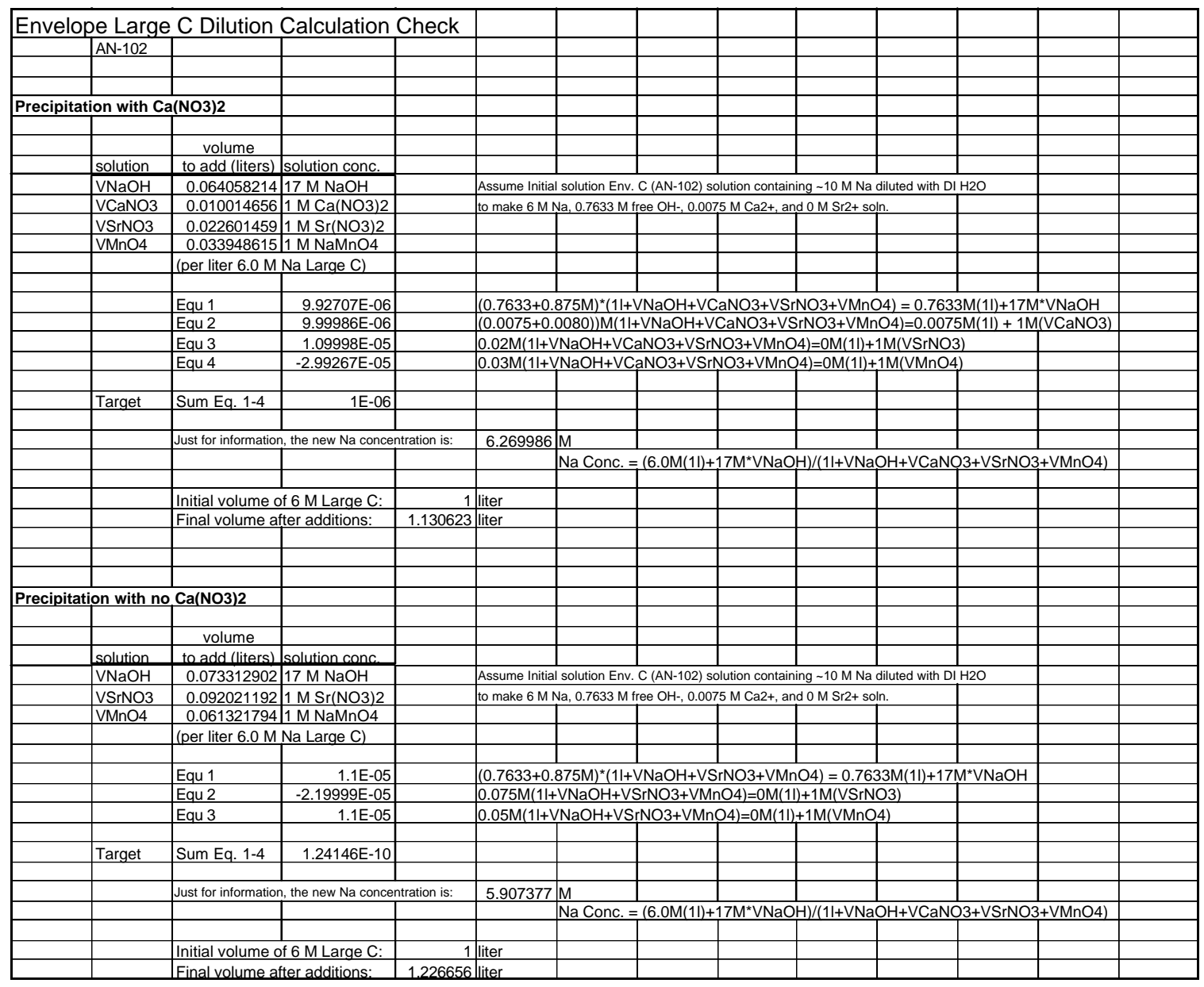




\section{APPENDIX C}

\section{FINAL PRODUCT COMPOSITE ANALYSES}

Main products from the Large $\mathrm{C}$ precipitation and filtration campaign are provided on the pages C-2 and C-3, following. The filtrate product was sampled after all 10 filtrate bottles plus four bottles of $600-\mathrm{ml}$ of wash solution were composited. This product was then forwarded to cesium ion exchange.

The washed slurry product was acid-digested with a final dilution factor of 30 to create the samples for analysis. Acid dissolution changes some analytes like anions so final analysis is not as extensive as that for filtrate. However, the metals and radioactive elemental analysis is valuable data for evaluating the process. It was planned that this product would be mixed with an Envelope D high level sludge for a vitrification test. 
Table C-1. Measured Composition of the Grand Filtrate Product Composite

\section{4}

ChemChek

U

\section{5}

\section{ICP-ES}

Analyte

$\mathrm{Ag}$

Al

$\mathrm{B}$

$\mathrm{Ca}$

$\mathrm{Cd}$

Co

$\mathrm{Cr}$

$\mathrm{Cu}$

$\mathrm{La}$
$\mathrm{Li}$

$\mathrm{Mg}$

$\mathrm{Mn}$

$\mathrm{Mo}$

$\mathrm{Ni}$

$\mathrm{P}$

$\mathrm{Pb}$

Sn

$\mathrm{Sr}$

$\mathrm{Ti}$

$\mathrm{Zn}$

$\mathrm{Zr}$

\section{3}

\section{Radiochem}

Sr-90

Pu-238

Pu-239-240

Am-241

$\mathrm{Cm}-244$

Cs-137

Cs-137 (uCi/mL)
Dilution-Corrected

$\mathrm{mg} / \mathrm{L}$

$$
\mathrm{mg} / \mathrm{L}
$$$$
0.126 \quad 12.6
$$

$\begin{array}{cc} & \\ & \mathrm{mg} / \mathrm{L} \\ & 0.006 \\ & 57.75 \\ & 0.156 \\ < & 0.002 \\ & 0.979 \\ & 0.241 \\ & 0.016 \\ & 0.93 \\ & 0.097 \\ & 0.025 \\ & 0.011 \\ & 0.002 \\ & 0.003 \\ & 0.012 \\ & 0.229 \\ & 1107.809 \\ 1.624 \\ 8.282 \\ & 0.581 \\ & 0.084 \\ & 0.175 \\ & 1.471 \\ & 0.002 \\ & 0.003 \\ & 0.027 \\ & 0.01\end{array}$

Dilution-Corrected

$\mathrm{mg} / \mathrm{L}$

0.6
5775

5775
15.6

< $\quad 0.2$

97.9

24.1

1.6

93
9.7

2.5

1.1

$<\quad 0.2$

0.3
1.2

22.9

110780.9

162.4

828.2

58.

8.4
17.5

147.1

$<\quad 0.2$

$\begin{array}{lll}1.471 & < & 0.2 \\ 0.003 & < & 0.3\end{array}$

0.01

\section{6}

F

\section{6}

Free $\mathrm{OH}$
Total $\mathrm{OH}$

\section{7}

IC Anion

Formate

Chloride

Nitrite

Nitrate

Phosphate

Sulfate

$4.82 \mathrm{M} \mathrm{Na}$

Oxalate

300145158

AA

$\mathrm{Na}$

mg/L

9.939
Dilution-Corrected

$$
\mathrm{mg} / \mathrm{L}
$$$$
1000
$$$$
1810
$$

Dilution-Corrected

$$
\text { Molarity }
$$

1.25

**Total less than free

Dilution-Corrected

$$
\mathrm{mg} / \mathrm{L}
$$

$$
600
$$

4200

2500

30300

82400

10000

\begin{tabular}{|c|c|c|}
\hline $\mathrm{dpm} / \mathrm{mL}$ & $\begin{array}{l}\text { Dilution-Corrected } \\
\mathrm{dpm} / \mathrm{mL}\end{array}$ & $\mathrm{uCi} / \mathrm{ml}$ \\
\hline $2.03 E+04$ & $2.03 E+06$ & 0.9144 \\
\hline $2.06 \mathrm{E}+01$ & $2.06 \mathrm{E}+03$ & 0.0009 \\
\hline $1.64 \mathrm{E}+01$ & $1.64 \mathrm{E}+03$ & 0.0007 \\
\hline $2.31 \mathrm{E}+02$ & $2.31 \mathrm{E}+04$ & 0.0104 \\
\hline $2.51 \mathrm{E}+02$ & $2.51 \mathrm{E}+04$ & 0.0113 \\
\hline $3.34 \mathrm{E}+06$ & $3.34 \mathrm{E}+08$ & 150.5225 \\
\hline
\end{tabular}

5000

10000
1

K

150.52 
Table C-2. Measured Composition of the Final Washed Precipitate Slurry

\begin{tabular}{|c|c|c|c|}
\hline Element & g/liter & & \\
\hline All & 1.037 & & \\
\hline $\mathrm{B}$ & 0.006 & & \\
\hline $\mathrm{Ba}$ & 0.026 & Cs-137 & $2.79 \mathrm{E}+07 \mathrm{dpm} / \mathrm{ml}$ \\
\hline $\mathrm{Ca}$ & 0.717 & Am-241 & $1.16 \mathrm{E}+06 \mathrm{dpm} / \mathrm{ml}$ \\
\hline $\mathrm{Cd}$ & 0.003 & Cm-244 & $4.94 \mathrm{E}+05 \mathrm{dpm} / \mathrm{ml}$ \\
\hline $\mathrm{Co}$ & 0.002 & Pu-239 & $3.51 \mathrm{E}+04 \mathrm{dpm} / \mathrm{ml}$ \\
\hline $\mathrm{Cr}$ & 0.303 & Pu-238 & $3.87 \mathrm{E}+04 \mathrm{dpm} / \mathrm{ml}$ \\
\hline $\mathrm{Cu}$ & 0.004 & & \\
\hline $\mathrm{Fe}$ & 0.121 & Sr-90 & $2.36 \mathrm{E}+08 \mathrm{dpm} / \mathrm{ml}$ \\
\hline $\mathrm{La}$ & 0.048 & Total U* & $6.9345 \mathrm{mg} / \mathrm{liter}$ \\
\hline $\mathrm{Li}$ & 0.001 & & \\
\hline $\mathrm{Mg}$ & 0.001 & & \\
\hline $\mathrm{Mn}$ & 13.728 & & \\
\hline $\mathrm{Mo}$ & 0.002 & & \\
\hline $\mathrm{Na}$ & 10.461 & & \\
\hline $\mathrm{Ni}$ & 0.073 & & \\
\hline $\mathrm{P}$ & 0.259 & & \\
\hline $\mathrm{Pb}$ & 0.140 & & \\
\hline $\mathrm{Si}$ & 3.681 & & \\
\hline $\mathrm{Sn}$ & 0.005 & & \\
\hline $\mathrm{Sr}$ & 30.306 & & \\
\hline $\mathrm{Tc}$ & 0.003 & & \\
\hline $\mathrm{Ti}$ & 0.001 & & \\
\hline $\mathrm{V}$ & 0.001 & & \\
\hline $\mathrm{Zn}$ & 0.019 & & \\
\hline $\mathrm{Zr}$ & 0.023 & & \\
\hline
\end{tabular}




\section{APPENDIX D}

\section{RAW ANALYTICAL DATA}

Analytical data for the campaign is archived in this appendix. Note that all samples were diluted 30 times; concentrations and activities in this section need to be multiplied by 30 to obtain sample values. 
Table D-2. Compositions for Digested Slurries (Concentrates) and Batch (Instantaneous) Filtrate Samples

Units: $\mathrm{mg} / \mathrm{liter}$

\begin{tabular}{|c|c|}
\hline \multicolumn{2}{|c|}{ Conc-5 } \\
\hline All & 33.698 \\
\hline $\mathrm{B}$ & 0.698 \\
\hline $\mathrm{Ba}$ & 0.193 \\
\hline $\mathrm{Ca}$ & 9.399 \\
\hline $\mathrm{Cd}$ & 0.853 \\
\hline Co & 0.050 \\
\hline $\mathrm{Cr}$ & 5.738 \\
\hline $\mathrm{Cu}$ & 0.209 \\
\hline $\mathrm{Fe}$ & 0.637 \\
\hline $\mathrm{La}$ & 0.155 \\
\hline $\mathrm{Li}$ & 0.020 \\
\hline $\mathrm{Mg}$ & 0.077 \\
\hline $\mathrm{Mn}$ & 163.461 \\
\hline Mo & 0.706 \\
\hline $\mathrm{Na}$ & 4192.144 \\
\hline $\mathrm{Ni}$ & 6.606 \\
\hline$P$ & 29.428 \\
\hline $\mathrm{Pb}$ & 3.273 \\
\hline $\mathrm{Si}$ & 144.580 \\
\hline $\mathrm{Sn}$ & 0.150 \\
\hline $\mathrm{Sr}$ & 311.051 \\
\hline $\mathrm{Tc}$ & 0.101 \\
\hline $\mathrm{Ti}$ & 0.020 \\
\hline $\mathrm{V}$ & 0.030 \\
\hline $\mathrm{Zn}$ & 0.181 \\
\hline $\mathrm{Zr}$ & 0.040 \\
\hline
\end{tabular}

\begin{tabular}{rrrr} 
Conc-6 & Filt-6 & \multicolumn{1}{l}{ Conc-7 } & Filt-7 \\
124.32 & 223.046 & 21.244 & 247.486 \\
0.641 & 0.57 & 0.628 & 0.587 \\
0.095 & 0.02 & 0.192 & 0.020 \\
7.741 & 4.964 & 9.235 & 5.057 \\
0.819 & 0.969 & 0.813 & 1.083 \\
0.05 & 0.085 & 0.050 & 0.100 \\
4.929 & 3.389 & 6.249 & 3.257 \\
0.201 & 0.384 & 0.201 & 0.446 \\
0.685 & 0.09 & 0.575 & 0.113 \\
0.11 & 0.11 & 0.110 & 0.110 \\
0.02 & 0.02 & 0.020 & 0.020 \\
0.025 & 0.01 & 0.014 & 0.010 \\
95.951 & 0.136 & 158.806 & 0.557 \\
0.722 & 0.978 & 0.689 & 1.050 \\
4246.906 & 4700.967 & 3715.728 & 5234.326 \\
6.156 & 6.374 & 6.191 & 7.213 \\
26.688 & 29.217 & 27.762 & 34.310 \\
2.539 & 2.378 & 3.235 & 2.668 \\
93.134 & 0.314 & 126.611 & 0.287 \\
0.247 & 0.611 & 0.151 & 0.818 \\
169.736 & 4.684 & 263.598 & 5.324 \\
0.07 & & 0.081 & \\
0.02 & 0.02 & 0.020 & 0.020 \\
0.03 & 0.035 & 0.030 & 0.030 \\
0.113 & 0.03 & 0.186 & 0.030 \\
0.04 & 1.144 & 0.040 & 0.497
\end{tabular}

Note: Data for the Filt-5 sample (instantaneous grab sample of Batch \#5 filtrate) are not available because of a dilution error for the ICP-ES method. 
Table D-3. Filtrate Product Bottle Compositions for the Ten Bottles

\begin{tabular}{|c|c|c|c|c|c|c|c|c|c|c|c|}
\hline \multirow[b]{2}{*}{ Below Det.: } & \multicolumn{2}{|c|}{ ALL } & ENTRIES & \multicolumn{2}{|c|}{$\mathrm{mg} / \mathrm{liter}$} & \multirow[b]{2}{*}{ Bottle 3} & \multirow[b]{2}{*}{$\begin{array}{l}\text { Bottle } 2 \\
5865.12\end{array}$} & \multirow[b]{2}{*}{$\begin{array}{l}\text { Bottle } 4 \\
5867.55\end{array}$} & \multirow[b]{2}{*}{$\begin{array}{l}\text { Bottle } 5 \\
6000.06\end{array}$} & \multirow[b]{2}{*}{$\begin{array}{l}\text { Bottle } 8 \\
6826.62\end{array}$} & \multirow[b]{2}{*}{$\begin{array}{r}\text { Bottle } 10 \\
7318.26\end{array}$} \\
\hline & $\begin{array}{l}\text { Element } \\
\mathrm{Al}\end{array}$ & $\begin{array}{l}\text { Bottle1 } \\
7318.26\end{array}$ & $\begin{array}{l}\text { Bottle } 6 \\
6720.945\end{array}$ & $\begin{array}{l}\text { Bottle } 7 \\
7069.56\end{array}$ & $\begin{array}{l}\text { Bottle } 9 \\
6549.09\end{array}$ & & & & & & \\
\hline \multirow{8}{*}{$x$} & $\mathrm{~B}$ & 18.39 & 16.935 & 17.13 & 17.01 & 18.93 & 17.49 & 15.93 & 16.59 & 17.97 & 18.39 \\
\hline & $\mathrm{Ba}$ & 0.6 & 0.3 & 0.6 & 0.6 & 2.55 & 2.37 & 2.4 & 2.28 & 0.87 & 0.6 \\
\hline & $\mathrm{Ca}$ & 151.71 & 112.185 & 121.44 & 156.72 & 140.58 & 232.98 & 96.84 & 100.05 & 146.67 & 151.71 \\
\hline & $\mathrm{Cd}$ & 32.34 & 28.425 & 30.06 & 30.9 & 28.71 & 26.19 & 24.09 & 25.17 & 31.59 & 32.34 \\
\hline & Co & 2.7 & 2.46 & 2.61 & 2.52 & 7.56 & 7.35 & 6.51 & 6.3 & 4.2 & 2.7 \\
\hline & $\mathrm{Cr}$ & 95.22 & 104.43 & 108.21 & 109.77 & 111.24 & 97.2 & 96 & 99.84 & 106.89 & 95.22 \\
\hline & $\mathrm{Cu}$ & 12.99 & 11.49 & 12.12 & 12.3 & 14.31 & 13.53 & 12.15 & 12.81 & 13.05 & 12.99 \\
\hline & $\mathrm{Fe}$ & 2.76 & 3.03 & 2.67 & 2.82 & 7.17 & 6.54 & 6.39 & 6.45 & 4.05 & 2.76 \\
\hline$x$ & $\mathrm{La}$ & 3.3 & 1.68 & 3.3 & 3.3 & 19.62 & 17.88 & 18.33 & 17.46 & 4.86 & 3.3 \\
\hline$x$ & $\mathrm{Li}$ & 0.6 & 0.3 & 0.6 & 0.6 & 3.33 & 3.03 & 3.15 & 3.03 & 0.99 & 0.6 \\
\hline \multirow[t]{10}{*}{$x$} & $\mathrm{Mg}$ & 0.3 & 0.15 & 0.3 & 0.3 & 0.3 & 0.42 & 0.33 & 0.3 & 0.3 & 0.3 \\
\hline & $\mathrm{Mn}$ & 3.84 & 3.615 & 2.31 & 3.33 & 7.68 & 2.34 & 2.52 & 5.37 & 4.86 & 3.84 \\
\hline & Mo & 30.6 & 27.75 & 29.52 & 30.93 & 28.32 & 25.86 & 24.54 & 25.29 & 30.84 & 30.6 \\
\hline & $\mathrm{Na}$ & 141383.04 & 137299.59 & 138780.69 & 146209.08 & 143753.22 & 119324.67 & 135310.65 & 136062.48 & 138323.7 & 141383.04 \\
\hline & $\mathrm{Ni}$ & 212.88 & 190.53 & 200.88 & 206.43 & 193.83 & 175.38 & 162.06 & 171.18 & 203.34 & 212.88 \\
\hline & $P$ & 946.71 & 926.25 & 940.65 & 879.99 & 966.54 & 842.43 & 840.15 & 867.93 & 947.16 & 946.71 \\
\hline & $\mathrm{Pb}$ & 80.04 & 67.59 & 73.47 & 80.04 & 85.92 & 84.6 & 74.94 & 83.94 & 88.05 & 80.04 \\
\hline & $\mathrm{Si}$ & 9.09 & 9.36 & 8.28 & 6.63 & 33.12 & 30.57 & 27.96 & 27.63 & 21.09 & 9.09 \\
\hline & $S n$ & 20.82 & 19.185 & 22.08 & 18.15 & 19.5 & 18.69 & 18.39 & 17.25 & 22.98 & 20.82 \\
\hline & Sr & 153.48 & 160.2 & 170.25 & 125.97 & 159.57 & 93.03 & 127.59 & 133.23 & 143.4 & 153.48 \\
\hline$x$ & $\mathrm{Ti}$ & 0.6 & 0.3 & 0.6 & 0.6 & 4.08 & 3.75 & 3.84 & 3.72 & 1.38 & 0.6 \\
\hline$x$ & V & 0.9 & 0.555 & 0.99 & 0.9 & 6.84 & 6.54 & 6.27 & 6.21 & 3.03 & 0.9 \\
\hline \multirow[t]{3}{*}{$x$} & $\mathrm{Zn}$ & 0.9 & 0.45 & 0.9 & 0.9 & 2.91 & 3.54 & 3.36 & 2.79 & 0.9 & 0.9 \\
\hline & $\mathrm{Zr}$ & 7.83 & 12.75 & 7.5 & 4.98 & 14.55 & 16.32 & 21.54 & 22.32 & 28.08 & 7.83 \\
\hline & Filt Bottle \# & 1 & 6 & 7 & 9 & 3 & 2 & 4 & 5 & 8 & 10 \\
\hline
\end{tabular}


Table D-4. Filtrate Activities for Ten Bottles

\begin{tabular}{|c|c|c|c|}
\hline Large & ADS LIMS \# & Sr-90 & Sample $\mu$ \\
\hline & Filtrate\#1 & $1.96 \mathrm{E}+05$ & \\
\hline Product & Filtrate\#2 & $7.68 \mathrm{E}+04$ & \\
\hline & Filtrate\#3 & $2.24 \mathrm{E}+05$ & \\
\hline & Filtrate\#4 & $9.45 E+04$ & \\
\hline & Filtrate\#5 & $8.69 E+04$ & \\
\hline & Filtrate\#6 & $1.43 E+05$ & \\
\hline & Filtrate\#7 & $6.83 E+04$ & \\
\hline & Filtrate\#8 & $7.08 \mathrm{E}+04$ & \\
\hline & Filtrate\#9 & $7.04 \mathrm{E}+04$ & \\
\hline & Filtrate\#10 & $6.86 \mathrm{E}+04$ & \\
\hline & & c-99, & ng/liter \\
\hline & Batch \#3 & 4.86 & \\
\hline & Batch \#4 & 5.04 & \\
\hline & Filtrate \#2 & 5.22 & \\
\hline & Filtrate \#3 & 5.46 & \\
\hline & Filtrate \#4 & 4.68 & \\
\hline & Filtrate \#5 & 4.86 & \\
\hline & Filtrate \#6 & 8.88 & \\
\hline & Filtrate \#9 & 5.19 & \\
\hline & Avg, St. dev. & 5.52375 & 1.378363 \\
\hline
\end{tabular}


Table D-5. Filtrate and Wash Solution Activities

Units for "Sample" (dilution corrected) are microcuries/ml

\begin{tabular}{lrrrrrrrrrr} 
ADS LIMS \# & Am-241 & \multicolumn{2}{c}{ Sample } & \multicolumn{1}{c}{ Cm-244 } & Sample & ADS \# & Pu239/240 & Sample & Pu238 & Sample \\
Filtrate\#1 & 2010 & 0.02716 & 1360 & 0.01838 & 135150 & 206 & 0.00278 & 138 & 0.00186 \\
Filtrate\#2 & 1890 & 0.02554 & 1130 & 0.01527 & 135202 & 91 & 0.00123 & 91 & 0.00123 \\
Filtrate\#3 & $1.39 \mathrm{E}+03$ & 0.01878 & $1.04 \mathrm{E}+03$ & 0.01405 & 135203 & $1.56 \mathrm{E}+02$ & 0.00211 & $1.02 \mathrm{E}+02$ & 0.00138 \\
Filtrate\#4 & $1.46 \mathrm{E}+03$ & 0.01973 & $1.25 \mathrm{E}+03$ & 0.01689 & 135204 & $3.40 \mathrm{E}+02$ & 0.00459 & $2.29 \mathrm{E}+02$ & 0.00309 \\
Filtrate\#5 & $8.74 \mathrm{E}+02$ & 0.01181 & $1.29 \mathrm{E}+03$ & 0.01743 & 135205 & $1.75 \mathrm{E}+02$ & 0.00236 & $1.24 \mathrm{E}+02$ & 0.00168 \\
Filtrate\#6 & $3.07 \mathrm{E}+03$ & 0.04149 & $2.71 \mathrm{E}+03$ & 0.03662 & 135206 & $2.18 \mathrm{E}+02$ & 0.00295 & $1.57 \mathrm{E}+02$ & 0.00212 \\
Filtrate\#7 & $2.10 \mathrm{E}+03$ & 0.02838 & $1.59 \mathrm{E}+03$ & 0.02149 & 135207 & $1.12 \mathrm{E}+02$ & 0.00151 & $1.05 \mathrm{E}+02$ & 0.00142 \\
Filtrate\#8 & $2.33 \mathrm{E}+03$ & 0.03149 & $8.26 \mathrm{E}+03$ & 0.11162 & 135208 & $1.05 \mathrm{E}+02$ & 0.00142 & $7.12 \mathrm{E}+01$ & 0.00096 \\
Filtrate\#9 & $2.08 \mathrm{E}+03$ & 0.02811 & $1.18 \mathrm{E}+03$ & 0.01595 & 135209 & $1.00 \mathrm{E}+02$ & 0.00135 & $8.33 \mathrm{E}+01$ & 0.00113 \\
Filtrate\#10 & $8.77 \mathrm{E}+02$ & 0.01185 & $8.85 \mathrm{E}+02$ & 0.01196 & 135210 & $1.38 \mathrm{E}+02$ & 0.00186 & $9.03 \mathrm{E}+01$ & 0.00122 \\
Wash \#1 & $3.10 \mathrm{E}+02$ & 0.00419 & $2.68 \mathrm{E}+02$ & 0.00362 & 135214 & $4.88 \mathrm{E}+01$ & 0.00066 & $3.49 \mathrm{E}+01$ & 0.00047 \\
Wash \#2 & $2.17 \mathrm{E}+02$ & 0.00293 & $4.07 \mathrm{E}+02$ & 0.00550 & 135216 & $2.88 \mathrm{E}+01$ & 0.00039 & $1.55 \mathrm{E}+01$ & 0.00021 \\
Wash \#3 & $1.52 \mathrm{E}+02$ & 0.00205 & $2.23 \mathrm{E}+02$ & 0.00301 & 135218 & $9.08 \mathrm{E}+00$ & 0.00012 & $5.97 \mathrm{E}+00$ & 0.00008 \\
Wash \#4 & $1.05 \mathrm{E}+02$ & 0.00142 & $8.92 \mathrm{E}+01$ & 0.00121 & 135220 & $2.63 \mathrm{E}+01$ & 0.00036 & $1.47 \mathrm{E}+01$ & 0.00020
\end{tabular}


Table D-6. Digested Slurry Compositions for the Four Washes - Duplicate Measurements Units: $\mathrm{mg} / \mathrm{liter}$

\begin{tabular}{|c|c|c|c|c|c|c|c|c|}
\hline ADS\# & $\begin{array}{c}\text { WashConc-1 } \\
\text { 3-135222 }\end{array}$ & $\begin{array}{c}\text { WashConc-1 } \\
3-135223\end{array}$ & $\begin{array}{c}\text { WashConc-2 } \\
3-135224\end{array}$ & $\begin{array}{c}\text { WashConc-2 } \\
\text { 3-135225 }\end{array}$ & $\begin{array}{c}\text { WashConc-3 } \\
3-135226\end{array}$ & $\begin{array}{c}\text { WashConc-3 } \\
3-135227\end{array}$ & $\begin{array}{c}\text { WashConc-4 } \\
3-135228\end{array}$ & $\begin{array}{c}\text { WashConc-4 } \\
\text { 3-135229 }\end{array}$ \\
\hline All & 43.745 & 43.82 & 16.164 & 20.806 & 29.335 & 36.54 & 39.796 & 29.358 \\
\hline $\mathrm{B}$ & 0.295 & 0.338 & 0.132 & 0.239 & 0.192 & 0.257 & 0.191 & 0.206 \\
\hline $\mathrm{Ca}$ & 10.619 & 10.546 & 6.851 & 8.697 & 14.492 & 22.251 & 25.61 & 22.187 \\
\hline $\mathrm{Cd}$ & 0.291 & 0.23 & 0.036 & 0.043 & 0.05 & 0.101 & 0.093 & 0.077 \\
\hline $\mathrm{Co}$ & 0.05 & 0.05 & 0.05 & 0.05 & 0.05 & 0.05 & 0.05 & 0.05 \\
\hline $\mathrm{Cu}$ & 0.085 & 0.1 & 0.03 & 0.03 & 0.051 & 0.111 & 0.126 & 0.116 \\
\hline $\mathrm{Fe}$ & 1.909 & 2.454 & 1.363 & 1.451 & 3.129 & 3.847 & 4.661 & 3.436 \\
\hline $\mathrm{La}$ & 0.355 & 0.483 & 0.328 & 0.437 & 1.001 & 1.192 & 2.175 & 1.038 \\
\hline $\mathrm{Li}$ & 0.02 & 0.02 & 0.02 & 0.02 & 0.02 & 0.02 & 0.02 & 0.02 \\
\hline $\mathrm{Mg}$ & 0.021 & 0.02 & 0.01 & 0.02 & 0.06 & 0.096 & 0.047 & 0.044 \\
\hline $\mathrm{Mn}$ & 244.247 & 303.447 & 152.388 & 190.727 & 326.716 & 442.463 & 502.911 & 412.278 \\
\hline $\mathrm{Mo}$ & 0.215 & 0.178 & 0.06 & 0.06 & 0.06 & 0.06 & 0.06 & 0.06 \\
\hline $\mathrm{Ni}$ & 3.072 & 2.895 & 0.926 & 1.181 & 1.699 & 2.481 & 2.661 & 2.237 \\
\hline $\mathrm{P}$ & 10.595 & 9.31 & 2.772 & 3.531 & 4.734 & 7.902 & 9.017 & 8.268 \\
\hline $\mathrm{Pb}$ & 2.356 & 2.6 & 1.123 & 1.532 & 2.723 & 4.477 & 5.021 & 4.281 \\
\hline Si & 109.469 & 94.879 & 150.702 & 100.128 & 152.007 & 134.974 & 152.329 & 93.097 \\
\hline $\mathrm{Sn}$ & 0.168 & 0.15 & 0.15 & 0.15 & 0.15 & 0.15 & 0.15 & 0.15 \\
\hline $\mathrm{Sr}$ & 434.051 & 474.349 & 321.065 & 397.209 & 684.145 & 975.395 & 1131.351 & 889.058 \\
\hline $\mathrm{Tc}$ & 0.085 & 0.085 & 0.07 & 0.07 & 0.07 & 0.07 & 0.07 & 0.107 \\
\hline $\mathrm{Ti}$ & 0.02 & 0.02 & 0.02 & 0.02 & 0.02 & 0.02 & 0.02 & 0.02 \\
\hline $\mathrm{V}$ & 0.03 & 0.03 & 0.03 & 0.03 & 0.03 & 0.03 & 0.03 & 0.03 \\
\hline $\mathrm{Zn}$ & 0.231 & 0.273 & 0.174 & 0.189 & 0.339 & 0.567 & 0.672 & 0.598 \\
\hline $\mathrm{Zr}$ & 1.808 & 0.658 & 0.299 & 0.45 & 0.505 & 0.753 & 0.953 & 0.603 \\
\hline
\end{tabular}


Table D-7. Digested Slurry Activities for the Four Washes - Duplicate Measurements Units: dpm/ml, though Uranium is $\mathrm{mg} / \mathrm{liter}$

\begin{tabular}{|c|c|c|c|c|c|c|c|c|}
\hline & WashConc-1 & WashConc-1 & WashConc-2 & WashConc-2 & WashConc-3 & WashConc-3 & WashConc-4 & WashConc-4 \\
\hline ADS\# & 3-135222 & 3-135223 & 3-135224 & 3-135225 & $3-135226$ & 3-135227 & 3-135228 & 3-135229 \\
\hline Cs-137 & $4.20 \mathrm{E}+06$ & $3.50 E+06$ & $6.51 \mathrm{E}+05$ & $9.46 \mathrm{E}+05$ & $7.68 \mathrm{E}+04$ & $1.23 E+06$ & $9.95 \mathrm{E}+05$ & $8.62 E+05$ \\
\hline Eu-154 & & & & & & $4.31 \mathrm{E}+04$ & & \\
\hline Eu-155 & & & & & & $2.10 \mathrm{E}+04$ & & \\
\hline Co-60 & & & & & & & & \\
\hline Am-241 & $1.55 \mathrm{E}+04$ & $1.50 E+04$ & $1.20 E+04$ & $1.45 E+04$ & $2.56 \mathrm{E}+04$ & $3.57 E+04$ & $4.24 \mathrm{E}+04$ & $3.46 E+04$ \\
\hline $\mathrm{Cm}-244$ & $5.65 \mathrm{E}+03$ & $6.14 \mathrm{E}+03$ & $6.28 E+03$ & $5.66 \mathrm{E}+03$ & $1.04 \mathrm{E}+04$ & $1.37 \mathrm{E}+04$ & $1.71 \mathrm{E}+04$ & $1.58 \mathrm{E}+04$ \\
\hline Pu-239 & $4.99 \mathrm{E}+02$ & $5.34 \mathrm{E}+02$ & $5.14 \mathrm{E}+02$ & $4.96 \mathrm{E}+02$ & $7.07 \mathrm{E}+02$ & $1.17 \mathrm{E}+03$ & $1.23 \mathrm{E}+03$ & $1.11 \mathrm{E}+03$ \\
\hline Pu-238 & $4.64 \mathrm{E}+02$ & $5.48 \mathrm{E}+02$ & $1.59 \mathrm{E}+03$ & $4.41 \mathrm{E}+02$ & $1.14 \mathrm{E}+03$ & $9.85 \mathrm{E}+02$ & $1.08 \mathrm{E}+03$ & $1.50 \mathrm{E}+03$ \\
\hline Sr-90 & $6.02 E+06$ & $7.70 \mathrm{E}+06$ & $4.96 \mathrm{E}+06$ & $6.02 E+06$ & $1.14 \mathrm{E}+07$ & $1.64 \mathrm{E}+07$ & $1.57 \mathrm{E}+07$ & \\
\hline Total U & 0.162 & 0.2108 & 0.1204 & 0.1361 & 0.1562 & 0.251 & 0.288 & 0.1743 \\
\hline
\end{tabular}


Table D-8. Wash Filtrate ICP-ES Data - Duplicate Measurements Units: $\mathrm{mg} / \mathrm{liter}$

\begin{tabular}{|c|c|}
\hline ADS \#> & $\begin{array}{c}\text { Wash-1 } \\
3-135214\end{array}$ \\
\hline $\mathrm{Al}$ & 122.457 \\
\hline$B$ & 0.265 \\
\hline $\mathrm{Ba}$ & 0.020 \\
\hline $\mathrm{Ca}$ & 3.530 \\
\hline $\mathrm{Cd}$ & 0.547 \\
\hline Co & 0.067 \\
\hline $\mathrm{Cr}$ & 0.739 \\
\hline $\mathrm{Cu}$ & 0.248 \\
\hline $\mathrm{Fe}$ & 0.063 \\
\hline $\mathrm{La}$ & 0.110 \\
\hline $\mathrm{Li}$ & 0.020 \\
\hline $\mathrm{Mg}$ & 0.010 \\
\hline $\mathrm{Mn}$ & 0.262 \\
\hline Mo & 0.549 \\
\hline $\mathrm{Na}$ & 2471.210 \\
\hline $\mathrm{Ni}$ & 3.634 \\
\hline $\mathrm{P}$ & 15.876 \\
\hline $\mathrm{Pb}$ & 1.760 \\
\hline Si & 0.190 \\
\hline Sn & 0.341 \\
\hline $\mathrm{Sr}$ & 2.666 \\
\hline $\mathrm{Ti}$ & 0.020 \\
\hline V & 0.030 \\
\hline $\mathrm{Zn}$ & 0.030 \\
\hline $\mathrm{Zr}$ & 0.115 \\
\hline
\end{tabular}

Wash-1
$3-135215$
107.351
0.237
0.02
3.163
0.487
0.05
0.703
0.236
0.064
0.11
0.02
0.01
0.416
0.632
2151.436
3.292
14.407
1.816
0.205
0.398
2.328
0.02
0.039
0.03
0.26

\begin{tabular}{rr}
\multicolumn{1}{c}{ Wash-2 } & \multicolumn{1}{c}{ Wash-2 } \\
$3-135216$ & $3-135217$ \\
46.765 & 50.932 \\
0.078 & 0.109 \\
0.02 & 0.02 \\
1.956 & 1.952 \\
0.243 & 0.268 \\
0.061 & 0.059 \\
0.351 & 0.496 \\
0.13 & 0.136 \\
0.042 & 0.049 \\
0.11 & 0.11 \\
0.02 & 0.02 \\
0.01 & 0.01 \\
0.01 & 0.097 \\
0.205 & 0.331 \\
1037.82 & 1173.648 \\
1.654 & 1.727 \\
5.154 & 5.827 \\
1.14 & 1.293 \\
0.161 & 0.188 \\
0.231 & 0.152 \\
1.736 & 1.108 \\
0.02 & 0.02 \\
0.052 & 0.056 \\
0.03 & 0.03 \\
0.04 & 0.049
\end{tabular}

Wash-3
3-135218
27.741
0.05
0.022
1.475
0.123
0.071
0.604
0.087
0.04
0.11
0.024
0.01
0.015
0.127
549.071
0.834
2.199
0.691
0.236
0.15
1.019
0.035
0.076
0.03
0.064

Wash-3
$3-135219$
26.262
0.05
0.02
1.365
0.121
0.053
0.585
0.094
0.03
0.11
0.02
0.01
0.01
0.103
555.784
0.898
2.364
0.596
0.172
0.15
0.926
0.028
0.06
0.03
0.054

\begin{tabular}{rr}
\multicolumn{1}{c}{ Wash-4 } & \multicolumn{1}{c}{ Wash-4 } \\
$3-135220$ & $3-135221$ \\
13.287 & 13.792 \\
0.05 & 0.05 \\
0.025 & 0.02 \\
1.002 & 0.966 \\
0.068 & 0.054 \\
0.068 & 0.05 \\
0.282 & 0.271 \\
0.062 & 0.048 \\
0.041 & 0.03 \\
0.11 & 0.11 \\
0.025 & 0.02 \\
0.01 & 0.01 \\
0.01 & 0.01 \\
0.065 & 0.062 \\
260.836 & 269.969 \\
0.383 & 0.441 \\
0.739 & 1.062 \\
0.477 & 0.398 \\
0.219 & 0.16 \\
0.15 & 0.15 \\
0.576 & 0.653 \\
0.04 & 0.022 \\
0.083 & 0.057 \\
0.03 & 0.03 \\
0.076 & 0.046
\end{tabular}


Table D-9. Wash Filtrate Activities - Duplicate Measurements Units: $\mathrm{dpm} / \mathrm{ml}$

\begin{tabular}{|c|c|c|c|c|c|c|c|c|}
\hline ADS \#> & $\begin{array}{c}\text { Wash-1 } \\
\text { 3-135214 }\end{array}$ & $\begin{array}{c}\text { Wash-1 } \\
\text { 3-135215 }\end{array}$ & $\begin{array}{c}\text { Wash-2 } \\
\text { 3-135216 }\end{array}$ & $\begin{array}{c}\text { Wash-2 } \\
3-135217\end{array}$ & $\begin{array}{l}\text { Wash-3 } \\
\text { 3-135218 }\end{array}$ & $\begin{array}{c}\text { Wash-3 } \\
\text { 3-135219 }\end{array}$ & $\begin{array}{l}\text { Wash-4 } \\
\text { 3-135220 }\end{array}$ & $\begin{array}{l}\text { Wash-4 } \\
\text { 3-135221 }\end{array}$ \\
\hline $\begin{array}{l}\text { Cs-137 } \\
\text { Eu-154 } \\
\text { Eu-155 }\end{array}$ & $6.95 E+06$ & $6.85 E+06$ & $2.75 E+06$ & $3.30 E+06$ & $1.38 E+06$ & $1.40 \mathrm{E}+06$ & $6.13 E+05$ & 7.21E+05 \\
\hline Co-60 & $1.76 \mathrm{E}+03$ & 1.63E+03 & 5.29E+02 & $8.45 E+02$ & & & 1.57E+02 & $1.99 \mathrm{E}+02$ \\
\hline Am-241 & $3.10 \mathrm{E}+02$ & $2.22 E+02$ & 217 & 142 & 152 & 130 & 105 & 113 \\
\hline Cm-244 & 2.68E+02 & $2.00 \mathrm{E}+02$ & 407 & 312 & 223 & 44.4 & 89.2 & 120 \\
\hline Pu-239 & 48.8 & 77.9 & 28.8 & 27.5 & 9.08 & 51.7 & 26.3 & 44.9 \\
\hline Pu-238 & 34.9 & 43.4 & 15.5 & 13.7 & 5.97 & 19.7 & 14.7 & 14.7 \\
\hline Tc-99 & 2.57E+04 & 1.47E+04 & & $E+04$ & & & & \\
\hline Sr-90 & $5.35 E+04$ & $4.52 \mathrm{E}+04$ & $2.98 \mathrm{E}+04$ & 2.97E+04 & $1.75 \mathrm{E}+04$ & $1.71 \mathrm{E}+04$ & $9.83 E+03$ & $1.00 \mathrm{E}+04$ \\
\hline
\end{tabular}

Table D-10. Flush Liquid Activities Units: dpm/ml

$\begin{array}{lrrrrrrr} & \text { WaterFlush } & \text { WaterFlush } & \text { 1 M Nitric } & \text { 1 M Nitric } & \text { Final Water } & \text { Final Water } \\ \text { ADS \#> } & 136882 & 136884 & 136885 & 136886 & 136887 & 136888 \\ & & & & & & \\ \text { Sr-90 } & 3.92 \mathrm{E}+06 & 3.84 \mathrm{E}+06 & 2.40 \mathrm{E}+06 & 3.39 \mathrm{E}+06 & 5.22 \mathrm{E}+05 & 7.13 \mathrm{E}+05 \\ \text { Am-241 } & 8330 & 8050 & 6240 & 6030 & 1470 & 1380 \\ \text { Cm-244 } & 3070 & 3300 & 2450 & 2450 & 584 & 581 \\ \text { Pu-239 } & 290 & 251 & 232 & 172 & 80 & 67 \\ \text { Pu-238 } & 323 & 163 & 192 & 159 & 76 & 156 \\ \text { Cs-137 } & 2.00 \mathrm{E}+05 & 1.94 \mathrm{E}+05 & 2.92 \mathrm{E}+05 & 2.98 \mathrm{E}+05 & 9.74 \mathrm{E}+04 & 9.16 \mathrm{E}+04 \\ \text { Tc-99 } & 1440 & 1760 & 1840 & 2020 & 1620 & 475 \\ \text { Eu-154 } & 9.01 \mathrm{E}+03 & 8.97 \mathrm{E}+03 & 6.79 \mathrm{E}+03 & 6.78 \mathrm{E}+03 & 1.75 \mathrm{E}+03 & 1.31 \mathrm{E}+03\end{array}$


Table D-11. Flush Liquid Compositions, mg/liter

$\begin{array}{lrrrrrr} & \text { WaterFlush } & \text { WaterFlush } & \text { M Nitric } & \text { 1 M Nitric } & \text { Final Water } & \text { Final Water } \\ \mathrm{ADS} \#> & 882 & 884 & 885 & 886 & 887 & 888 \\ \mathrm{Al} & 9.98 & 9.787 & 10.17 & 10.517 & 2.048 & 1.981 \\ \mathrm{~B} & 0.05 & 0.05 & 0.05 & 0.050 & 0.05 & 0.05 \\ \mathrm{Ba} & 0.138 & 0.133 & 0.096 & 0.073 & 0.02 & 0.02 \\ \mathrm{Ca} & 5.59 & 5.567 & 4.499 & 4.603 & 1.908 & 1.87 \\ \mathrm{Cd} & 0.03 & 0.03 & 0.03 & 0.030 & 0.03 & 0.03 \\ \mathrm{Ce} & 3.841 & 3.573 & 3.15 & 3.150 & 3.15 & 3.15 \\ \mathrm{Co} & 0.05 & 0.05 & 0.05 & 0.050 & 0.05 & 0.05 \\ \mathrm{Cr} & 1.972 & 1.907 & 1.479 & 1.494 & 0.308 & 0.272 \\ \mathrm{Cu} & 0.03 & 0.03 & 0.03 & 0.030 & 0.228 & 0.223 \\ \mathrm{Fe} & 1.057 & 1.042 & 1.018 & 1.038 & 0.304 & 0.276 \\ \mathrm{La} & 0.2 & 0.165 & 0.11 & 0.110 & 0.11 & 0.11 \\ \mathrm{Li} & 0.02 & 0.02 & 0.02 & 0.020 & 0.02 & 0.02 \\ \mathrm{Mg} & 0.038 & 0.034 & 0.034 & 0.034 & 0.068 & 0.067 \\ \mathrm{Mn} & 108.695 & 107.173 & 85.714 & 88.975 & 17.084 & 17.042 \\ \mathrm{Mo} & 0.06 & 0.06 & 0.06 & 0.060 & 0.06 & 0.06 \\ \mathrm{Na} & 78.572 & 77.186 & 98.868 & 103.003 & 41.249 & 41.138 \\ \mathrm{Ni} & 0.546 & 0.479 & 0.501 & 0.424 & 0.07 & 0.07 \\ \mathrm{P} & 1.716 & 1.629 & 1.407 & 1.407 & 0.263 & 0.451 \\ \mathrm{~Pb} & 0.54 & 0.492 & 0.373 & 0.480 & 0.28 & 0.28 \\ \mathrm{Si} & 0.16 & 0.16 & 0.16 & 0.160 & 0.16 & 0.16 \\ \mathrm{Sn} & 0.15 & 0.15 & 0.15 & 0.150 & 0.15 & 0.15 \\ \mathrm{Sr} & 233.232 & 231.35 & 171.216 & 178.044 & 41.95 & 41.952 \\ \mathrm{Ti} & 0.02 & 0.02 & 0.02 & 0.020 & 0.02 & 0.02 \\ \mathrm{~V} & 0.03 & 0.03 & 0.03 & 0.030 & 0.03 & 0.03 \\ \mathrm{Zn} & 0.118 & 0.111 & 0.099 & 0.096 & 0.059 & 0.052 \\ \mathrm{Zr} & 0.125 & 0.095 & 0.086 & 0.075 & 0.04 & 0.04 \\ & & & & & & \end{array}$




\section{APPENDIX E}

\section{RAW FILTRATION DATA}

The raw data from the filtration work is archived in this section. 


\section{Batch \#1 Data}

\begin{tabular}{|c|c|c|c|c|c|c|c|c|c|c|c|}
\hline \multicolumn{12}{|c|}{ Ca Precipitation/Filtration Flux Data } \\
\hline \multicolumn{12}{|c|}{ Large C precipitation/filtration Run \#1 } \\
\hline \multicolumn{12}{|c|}{ 11/10/99 - 11/12/99 } \\
\hline \multicolumn{3}{|c|}{ TMP $=50$ psig, $12.2 \mathrm{ft} / \mathrm{s}$ fluid velocity } & & & & & & Permeate & Permeate & & \\
\hline & & (P1-P2) & F1 (gpm) & F2 vol. (ml) & F2 time & $\mathrm{F} 2$ & F2 & Flux & Flux & Permeance & Permeance \\
\hline Time (min) & Temp (F) & TMP (psi) & Filter Flow & Filtrate Vol. & Time (sec) & $\mathrm{mL} / \mathrm{sec}$ & $\mathrm{ml} / \mathrm{min}$ & GPM/ft*ft & $\mathrm{m3} /\left(\mathrm{m} 2^{*}\right.$ day $)$ & (gpm/ft2 psi) & $\mathrm{m3} /\left(\mathrm{m} 2^{*}\right.$ day $^{*}$ bar $)$ \\
\hline 0 & 87 & 50 & \begin{tabular}{|l|l}
3.80 \\
\end{tabular} & 30 & 9.61 & 3.12 & 187.30 & 0.252 & 14.782 & 0.0050 & 4.288 \\
\hline 5 & 85 & 50 & 3.76 & 20 & 9.18 & 2.18 & 130.72 & 0.176 & 10.316 & 0.0035 & 2.993 \\
\hline 10 & 84 & 50 & 3.93 & 20 & 11.04 & 1.81 & 108.70 & 0.146 & 8.578 & 0.0029 & 2.488 \\
\hline 20 & 85 & 50 & 3.98 & 20 & 13.17 & 1.52 & 91.12 & 0.123 & 7.191 & 0.0025 & 2.086 \\
\hline 30 & 86 & 50 & 4.01 & 20 & 13.15 & 1.52 & 91.25 & 0.123 & 7.202 & 0.0025 & 2.089 \\
\hline 40 & 86 & 50 & 3.86 & 20 & 13.95 & 1.43 & 86.02 & 0.116 & 6.789 & 0.0023 & 1.969 \\
\hline 50 & 86 & 50 & 4.00 & 20 & 15.00 & 1.33 & 80.00 & 0.108 & 6.314 & 0.0022 & 1.831 \\
\hline \multirow[t]{2}{*}{60} & 84 & 50 & 4.07 & 20 & 17.42 & 1.15 & 68.89 & 0.093 & 5.437 & 0.0019 & 1.577 \\
\hline & & & & & & & & & & & \\
\hline \multicolumn{3}{|c|}{ TMP=30 psig, $9.1 \mathrm{ft} / \mathrm{s}$ fluid velocity } & & & & & & Permeate & Permeate & & \\
\hline & & (P1-P2) & \begin{tabular}{|l|} 
F1 (gpm) \\
\end{tabular} & F2 vol. (ml) & F2 time & $\mathrm{F} 2$ & $\mathrm{~F} 2$ & Flux & Flux & Permeance & Permeance \\
\hline Time (min) & Temp (F) & TMP (psi) & Filter Flow & Filtrate Vol. & Time (sec) & $\mathrm{mL} / \mathrm{sec}$ & $\mathrm{ml} / \mathrm{min}$ & GPM/ft*ft & $\mathrm{m} 3 /\left(\mathrm{m} 2^{\star}\right.$ day $)$ & (gpm/ft2 psi) & $\mathrm{m3} /\left(\mathrm{m} 2^{*}\right.$ day $^{*}$ bar $)$ \\
\hline 0 & 85 & 30 & 3.07 & 20 & 12.90 & 1.55 & 93.02 & 0.125 & 7.341 & 0.00417 & 3.549 \\
\hline 5 & 85 & 30 & 3.00 & 20 & 15.33 & 1.30 & 78.28 & 0.105 & 6.178 & 0.00351 & 2.987 \\
\hline 10 & 83 & 30 & 3.11 & 20 & 18.27 & 1.09 & 65.68 & 0.088 & 5.184 & 0.00294 & 2.506 \\
\hline 20 & 83 & 30 & 3.03 & 20 & 19.62 & 1.02 & 61.16 & 0.082 & 4.827 & 0.00274 & 2.334 \\
\hline 30 & 85 & 30 & 3.05 & 20 & 18.10 & 1.10 & 66.30 & 0.089 & 5.232 & 0.00297 & 2.530 \\
\hline 40 & 86 & 30 & 3.00 & 20 & 20.12 & 0.99 & 59.64 & 0.080 & 4.707 & 0.00267 & 2.276 \\
\hline 50 & 84 & 30 & 3.05 & 20 & 21.88 & 0.91 & 54.84 & 0.074 & 4.328 & 0.00246 & 2.093 \\
\hline \multirow[t]{2}{*}{60} & 84 & 30 & 3.06 & 20 & 20.82 & 0.96 & 57.64 & 0.078 & 4.549 & 0.00258 & 2.199 \\
\hline & & & & & & & & & & & \\
\hline \multicolumn{3}{|c|}{ TMP=30 psig, $15.2 \mathrm{ft} / \mathrm{s}$ fluid velocity } & & & & & & Permeate & Permeate & & \\
\hline & & (P1-P2) & F1 (gpm) & F2 vol. (ml) & F2 time & $\mathrm{F} 2$ & $\mathrm{~F} 2$ & Flux & Flux & Permeance & Permeance \\
\hline Time (min) & Temp (F) & TMP (psi) & Filter Flow & Filtrate Vol. & Time (sec) & $\mathrm{mL} / \mathrm{sec}$ & $\mathrm{ml} / \mathrm{min}$ & $\mathrm{GPM} / \mathrm{ft}^{\star} \mathrm{ft}$ & $\mathrm{m} 3 /\left(\mathrm{m} 2^{\star}\right.$ day $)$ & (gpm/ft2 psi) & $\mathrm{m3} /\left(\mathrm{m} 2^{*}\right.$ day $^{*}$ bar $)$ \\
\hline 0 & 87 & 30 & 5.11 & 20 & 15.65 & 1.28 & 76.68 & 0.103 & 6.051 & 0.00344 & 2.926 \\
\hline 5 & 87 & 30 & 5.06 & 20 & 21.11 & 0.95 & 56.85 & 0.076 & 4.486 & 0.00255 & 2.169 \\
\hline 10 & 87 & 30 & 4.98 & 20 & 22.53 & 0.89 & 53.26 & 0.072 & 4.203 & 0.00239 & 2.032 \\
\hline 20 & 83 & 31 & 5.04 & 20 & 27.39 & 0.73 & 43.81 & 0.059 & 3.458 & 0.00190 & 1.618 \\
\hline 30 & 85 & 30 & 5.13 & 20 & 29.41 & 0.68 & 40.80 & 0.055 & 3.220 & 0.00183 & 1.557 \\
\hline 40 & 83 & 30 & 5.14 & 20 & 31.50 & 0.63 & 38.10 & 0.051 & 3.006 & 0.00171 & 1.454 \\
\hline 50 & 81 & 30 & 5.06 & 20 & 37.16 & 0.54 & 32.29 & 0.043 & 2.549 & 0.00145 & 1.232 \\
\hline 60 & 84 & 30 & 5.13 & 20 & 30.88 & 0.65 & 38.86 & 0.052 & 3.067 & 0.00174 & 1.483 \\
\hline & & & & & & & & & & & \\
\hline \multicolumn{3}{|c|}{ TMP=70 psig, $9.1 \mathrm{ft} / \mathrm{s}$ fluid velocity } & & & & & & Permeate & Permeate & & \\
\hline & & (P1-P2) & F1 (gpm) & F2 vol. (ml) & F2 time & $\mathrm{F} 2$ & $\mathrm{~F} 2$ & Flux & Flux & Permeance & Permeance \\
\hline Time (min) & Temp (F) & TMP (psi) & Filter Flow & Filtrate Vol. & Time $(\mathrm{sec})$ & $\mathrm{mL} / \mathrm{sec}$ & $\mathrm{ml} / \mathrm{min}$ & GPM/ft*ft & $\mathrm{m} 3 /\left(\mathrm{m} 2^{\star}\right.$ day $)$ & (gpm/ft2 psi) & $\mathrm{m} 3 /\left(\mathrm{m} 2^{*}\right.$ day $^{*}$ bar $)$ \\
\hline 0 & 85 & 70 & 2.98 & 20 & 12.88 & 1.55 & 93.17 & 0.125 & 7.353 & 0.00179 & 1.523 \\
\hline 5 & 81 & 70 & 2.98 & 20 & 19.83 & 1.01 & 60.51 & 0.081 & 4.776 & 0.00116 & 0.990 \\
\hline 10 & 83 & 70 & 2.97 & 20 & 22.16 & 0.90 & 54.15 & 0.073 & 4.274 & 0.00104 & 0.885 \\
\hline 20 & 83 & 70 & 2.88 & 20 & 23.51 & 0.85 & 51.04 & 0.069 & 4.028 & 0.00098 & 0.835 \\
\hline 30 & 83 & 70 & 2.86 & 20 & 26.00 & 0.77 & 46.15 & 0.062 & 3.642 & 0.00089 & 0.755 \\
\hline 40 & 82 & 70 & 2.92 & 20 & 29.52 & 0.68 & 40.65 & 0.055 & 3.208 & 0.00078 & 0.665 \\
\hline 50 & 83 & 70 & 2.90 & 20 & 30.36 & 0.66 & 39.53 & 0.053 & 3.119 & 0.00076 & 0.646 \\
\hline \multirow[t]{2}{*}{60} & 85 & 70 & 2.93 & 20 & 29.41 & 0.68 & 40.80 & 0.055 & 3.220 & 0.00078 & 0.667 \\
\hline & & & & & & & & & & & \\
\hline \multicolumn{3}{|c|}{ TMP $=70 \mathrm{psig}, 13.5 \mathrm{ft} / \mathrm{s}$ fluid velocity } & & & & & & Permeate & Permeate & & \\
\hline & & (P1-P2) & F1 (gpm) & F2 vol. (ml) & F2 time & $\mathrm{F} 2$ & $\mathrm{~F} 2$ & Flux & Flux & Permeance & Permeance \\
\hline Time (min) & Temp (F) & TMP (psi) & Filter Flow & Filtrate Vol. & Time $(\mathrm{sec})$ & $\mathrm{mL} / \mathrm{sec}$ & $\mathrm{ml} / \mathrm{min}$ & $\mathrm{GPM} / \mathrm{ft}^{\star} \mathrm{ft}$ & $\mathrm{m} 3 /\left(\mathrm{m} 2^{*}\right.$ day $)$ & (gpm/ft2 psi) & $\mathrm{m3} /\left(\mathrm{m} 2^{*}\right.$ day $^{*}$ bar $)$ \\
\hline 0 & 86 & 70 & 4.35 & 20 & 11.31 & 1.77 & 106.10 & 0.143 & 8.374 & 0.0020 & 1.735 \\
\hline 5 & 87 & 70 & 4.30 & 20 & 17.21 & 1.16 & 69.73 & 0.094 & 5.503 & 0.0013 & 1.140 \\
\hline 10 & 81 & 70 & 4.29 & 20 & 19.22 & 1.04 & 62.43 & 0.084 & 4.927 & 0.0012 & 1.021 \\
\hline 20 & 87 & 70 & 4.51 & 20 & 19.96 & 1.00 & 60.12 & 0.081 & 4.745 & 0.0012 & 0.983 \\
\hline 30 & 87 & 70 & 4.36 & 20 & 22.42 & 0.89 & 53.52 & 0.072 & 4.224 & 0.0010 & 0.875 \\
\hline 40 & 86 & 70 & 4.34 & 20 & 23.49 & 0.85 & 51.09 & 0.069 & 4.032 & 0.0010 & 0.835 \\
\hline 50 & 88 & 70 & 4.37 & 20 & 23.70 & 0.84 & 50.63 & 0.068 & 3.996 & 0.0010 & 0.828 \\
\hline 60 & 88 & 70 & 4.41 & 20 & 26.40 & 0.76 & 45.45 & 0.061 & 3.587 & 0.0009 & 0.743 \\
\hline
\end{tabular}




\begin{tabular}{|c|c|c|c|c|c|c|c|c|c|c|c|}
\hline \multicolumn{4}{|c|}{ TMP=50 psig, $12.2 \mathrm{ft} / \mathrm{s}$ fluid velocity (Run \#2) } & & & & & \multirow{2}{*}{\begin{tabular}{|c|} 
Permeate \\
Flux
\end{tabular}} & \multirow{2}{*}{$\begin{array}{c}\text { Permeate } \\
\text { Flux }\end{array}$} & \multirow{2}{*}{\begin{tabular}{|l} 
Permeance \\
\end{tabular}} & \multirow{2}{*}{ Permeance } \\
\hline & & (P1-P2) & $\mathrm{F} 1$ (gpm) & F2 vol. (ml) & F2 time & $\mathrm{F} 2$ & $\mathrm{~F} 2$ & & & & \\
\hline Time (min) & Temp (F) & TMP (psi) & Filter Flow & Filtrate Vol. & Time (sec) & $\mathrm{mL} / \mathrm{sec}$ & $\mathrm{ml} / \mathrm{min}$ & $\mathrm{GPM} / \mathrm{ft}^{\star} \mathrm{ft}$ & $\mathrm{m} 3 /\left(\mathrm{m} 2{ }^{*} \mathrm{day}\right)$ & (apm/ft2 psi) & $\mathrm{m} 3 /\left(\mathrm{m} 2^{*} \mathrm{day}^{*} \mathrm{bar}\right)$ \\
\hline 0 & 86 & 50 & 3.83 & 20 & 16.92 & 1.18 & 70.92 & 0.095 & 5.597 & 0.0019 & 1.624 \\
\hline 5 & 84 & 50 & 3.89 & 20 & 20.67 & 0.97 & 58.06 & 0.078 & 4.582 & 0.0016 & 1.329 \\
\hline 10 & 86 & 50 & 3.94 & 20 & 25.88 & 0.77 & 46.37 & 0.062 & 3.659 & 0.0012 & 1.061 \\
\hline 20 & 86 & 50 & 3.95 & 20 & 23.92 & 0.84 & 50.17 & 0.067 & 3.959 & 0.0013 & 1.148 \\
\hline 30 & 86 & 50 & 3.91 & 20 & 25.58 & 0.78 & 46.91 & 0.063 & 3.702 & 0.0013 & 1.074 \\
\hline 40 & 83 & 50 & 3.90 & 20 & 26.47 & 0.76 & 45.33 & 0.061 & 3.578 & 0.0012 & 1.038 \\
\hline 50 & 84 & 50 & 3.85 & 20 & 27.38 & 0.73 & 43.83 & 0.059 & 3.459 & 0.0012 & 1.003 \\
\hline \multirow[t]{3}{*}{60} & 87 & 50 & 4.05 & 20 & 27.84 & 0.72 & 43.10 & 0.058 & 3.402 & 0.0012 & 0.987 \\
\hline & & & & & & & & & & & \\
\hline & & & & & & & & & & & \\
\hline \multicolumn{3}{|c|}{$\mathrm{TMP}=30 \mathrm{psig}, 12.2 \mathrm{ft} / \mathrm{s}$ fluid velocity } & & & & & & Permeate & Permeate & & \\
\hline & & (P1-P2) & F1 (gpm) & F2 vol. (ml) & F2 time & $\mathrm{F} 2$ & $\mathrm{~F} 2$ & Flux & Flux & Permeance & Permeance \\
\hline Time (min) & Temp (F) & TMP (psi) & Filter Flow & Filtrate Vol. & Time (sec) & $\mathrm{mL} / \mathrm{sec}$ & $\mathrm{ml} / \mathrm{min}$ & $\mathrm{GPM} / \mathrm{ft}^{\star} \mathrm{ft}$ & $\mathrm{m} 3 /\left(\mathrm{m} 2{ }^{*}\right.$ day $)$ & (gpm/ft2 psi) & $\mathrm{m} 3 /\left(\mathrm{m} 2^{*} \mathrm{day}^{*} \mathrm{bar}\right)$ \\
\hline 0 & 80 & 30 & 4.04 & 20 & 29.86 & 0.67 & 40.19 & 0.054 & 3.172 & 0.0018 & 1.533 \\
\hline 5 & 86 & 30 & 3.98 & 20 & 30.83 & 0.65 & 38.92 & 0.052 & 3.072 & 0.0017 & 1.485 \\
\hline 10 & 86 & 30 & 4.13 & 20 & 35.18 & 0.57 & 34.11 & 0.046 & 2.692 & 0.0015 & 1.301 \\
\hline 20 & 86 & 31 & 4.08 & 20 & 38.34 & 0.52 & 31.30 & 0.042 & 2.470 & 0.0014 & 1.156 \\
\hline 30 & 86 & 30 & 4.19 & 20 & 40.44 & 0.49 & 29.67 & 0.040 & 2.342 & 0.0013 & 1.132 \\
\hline 40 & 88 & 30 & 4.18 & 20 & 40.43 & 0.49 & 29.68 & 0.040 & 2.342 & 0.0013 & 1.132 \\
\hline \multicolumn{12}{|l|}{50} \\
\hline 60 & & & & & & & & & & & \\
\hline & & & & & & & & & & & \\
\hline & & & & & & & & & & & \\
\hline TMP $=50$ psig & $9.1 \mathrm{ft} / \mathrm{s}$ fluid & elocity (Run \# & & & & & & Permeate & Permeate & & \\
\hline & & (P1-P2) & F1 (gpm) & F2 vol. (ml) & F2 time & $\mathrm{F} 2$ & $\mathrm{~F} 2$ & Flux & Flux & Permeance & Permeance \\
\hline Time (min) & Temp (F) & TMP (psi) & Filter Flow & Filtrate Vol. & Time $(\mathrm{sec})$ & $\mathrm{mL} / \mathrm{sec}$ & $\mathrm{ml} / \mathrm{min}$ & GPM/ft*ft & $\mathrm{m3} /\left(\mathrm{m} 22^{*}\right.$ day $)$ & (gpm/ft2 psi) & m3/(m2* day ${ }^{*}$ bar $)$ \\
\hline 0 & 83 & 50 & 3.04 & 20 & 16.62 & 1.20 & 72.20 & 0.097 & 5.698 & 0.0019 & 1.653 \\
\hline 5 & 84 & 50 & 3.12 & 20 & 26.27 & 0.76 & 45.68 & 0.061 & 3.605 & 0.0012 & 1.046 \\
\hline 10 & 84 & 50 & 3.16 & 20 & 29.07 & 0.69 & 41.28 & 0.056 & 3.258 & 0.0011 & 0.945 \\
\hline 20 & 84 & 50 & 3.15 & 20 & 32.36 & 0.62 & 37.08 & 0.050 & 2.927 & 0.0010 & 0.849 \\
\hline 30 & 85 & 51 & 2.97 & 20 & 35.51 & 0.56 & 33.79 & 0.045 & 2.667 & 0.0009 & 0.758 \\
\hline 40 & 79 & 50 & 3.16 & 20 & 44.48 & 0.45 & 26.98 & 0.036 & 2.129 & 0.0007 & 0.618 \\
\hline 50 & 84 & 50 & 3.12 & 20 & 38.56 & 0.52 & 31.12 & 0.042 & 2.456 & 0.0008 & 0.712 \\
\hline 60 & 84 & 50 & 3.04 & 20 & 40.73 & 0.49 & 29.46 & 0.040 & 2.325 & 0.0008 & 0.674 \\
\hline 70 & 85 & 50 & 3.02 & 20 & 40.95 & 0.49 & 29.30 & 0.039 & 2.313 & 0.0008 & 0.671 \\
\hline & & & & & & & & & & & \\
\hline & & & & & & & & & & & \\
\hline $\mathrm{TMP}=30 \mathrm{psig}$ & , $6.6 \mathrm{ft} / \mathrm{s}$ fluid & elocity & & & & & & Permeate & Permeate & & \\
\hline & & (P1-P2) & $\mathrm{F} 1$ (gpm) & F2 vol. (ml) & F2 time & $\mathrm{F} 2$ & $\mathrm{~F} 2$ & Flux & Flux & Permeance & Permeance \\
\hline Time (min) & Temp (F) & TMP (psi) & Filter Flow & Filtrate Vol. & Time $(\mathrm{sec})$ & $\mathrm{mL} / \mathrm{sec}$ & $\mathrm{ml} / \mathrm{min}$ & GPM/ft*ft & $\mathrm{m} 3 /\left(\mathrm{m} 2^{*}\right.$ day $)$ & (gpm/ft2 psi) & $\mathrm{m3} /\left(\mathrm{m} 2^{*}\right.$ day $^{*}$ bar $)$ \\
\hline 0 & 84 & 30 & 2.17 & 20 & 23.80 & 0.84 & 50.42 & 0.068 & 3.979 & 0.0023 & 1.924 \\
\hline 5 & 82 & 30 & 2.23 & 20 & 35.84 & 0.56 & 33.48 & 0.045 & 2.642 & 0.0015 & 1.278 \\
\hline 10 & 82 & 30 & 2.15 & 20 & 39.53 & 0.51 & 30.36 & 0.041 & 2.396 & 0.0014 & 1.158 \\
\hline 20 & 84 & 30 & 2.29 & 20 & 41.53 & 0.48 & 28.89 & 0.039 & 2.280 & 0.0013 & 1.102 \\
\hline 30 & 80 & 30 & 2.18 & 20 & 47.76 & 0.42 & 25.13 & 0.034 & 1.983 & 0.0011 & 0.959 \\
\hline 40 & 84 & 30 & 2.20 & 20 & 47.78 & 0.42 & 25.12 & 0.034 & 1.982 & 0.0011 & 0.958 \\
\hline 50 & 84 & 30 & 2.25 & 20 & 49.81 & 0.40 & 24.09 & 0.032 & 1.901 & 0.0011 & 0.919 \\
\hline 60 & 84 & 30 & 2.19 & 20 & 52.16 & 0.38 & 23.01 & 0.031 & 1.816 & 0.0010 & 0.878 \\
\hline & & & & & & & & & & & \\
\hline & & & & & & & & & & & \\
\hline $\mathrm{TMP}=50 \mathrm{psig}$ &, $12.2 \mathrm{ft} / \mathrm{s}$ fluid & velocity (Run : & & & & & & Permeate & Permeate & & \\
\hline & & (P1-P2) & $\mathrm{F} 1$ (gpm) & F2 vol. (ml) & F2 time & $\mathrm{F} 2$ & $\mathrm{~F} 2$ & Flux & Flux & Permeance & Permeance \\
\hline Time (min) & Temp (F) & TMP (psi) & Filter Flow & Filtrate Vol. & Time (sec) & $\mathrm{mL} / \mathrm{sec}$ & $\mathrm{ml} / \mathrm{min}$ & GPM/ft*ft & $\mathrm{m3} /\left(\mathrm{m} 2^{*}\right.$ day $)$ & (gpm/ft2 psi) & $\mathrm{m} 3 /\left(\mathrm{m} 2^{*}\right.$ day $\left.^{*} \mathrm{bar}\right)$ \\
\hline 0 & 85 & 53 & 3.75 & 20 & 17.60 & 1.14 & 68.18 & 0.092 & 5.381 & 0.0017 & 1.473 \\
\hline 5 & 84 & 50 & 4.00 & 20 & 24.12 & 0.83 & 49.75 & 0.067 & 3.926 & 0.0013 & 1.139 \\
\hline 10 & 82 & 50 & 4.15 & 20 & 27.30 & 0.73 & 43.96 & 0.059 & 3.469 & 0.0012 & 1.006 \\
\hline 20 & 84 & 50 & 3.93 & 20 & 35.28 & 0.57 & 34.01 & 0.046 & 2.684 & 0.0009 & 0.779 \\
\hline 30 & 84 & 50 & 4.01 & 20 & 30.92 & 0.65 & 38.81 & 0.052 & 3.063 & 0.0010 & 0.888 \\
\hline 40 & 85 & 50 & 4.01 & 20 & 31.18 & 0.64 & 38.49 & 0.052 & 3.037 & 0.0010 & 0.881 \\
\hline 50 & 84 & 50 & 4.00 & 20 & 31.16 & 0.64 & 38.51 & 0.052 & 3.039 & 0.0010 & 0.882 \\
\hline 60 & 87 & 50 & 4.11 & 20 & 34.88 & 0.57 & 34.40 & 0.046 & 2.715 & 0.0009 & 0.788 \\
\hline & & & & & & & & & & & \\
\hline & & & & & & & & & & & \\
\hline & $\mathrm{F} 1=2.2 \mathrm{~g}$ & $\mathrm{~mm}=6.6 \mathrm{ft} / \mathrm{s}$ & $\mathrm{s}=2.01 \mathrm{~m} / \mathrm{s}$ & & 30 psig = & 2.068423 & & GPM = gal & ons/ft2 & & \\
\hline & $\mathrm{F} 1=3 \mathrm{gpn}$ & $\mathrm{n}=9.1 \mathrm{ft} / \mathrm{s}=$ & $=2.77 \mathrm{~m} / \mathrm{s}$ & & 50 psig = & 3.447372 & & & & & \\
\hline & $\mathrm{F} 1=4 \mathrm{gpn}$ & $=12.2 \mathrm{ft} / \mathrm{s}$ & $=3.72 \mathrm{~m} / \mathrm{s}$ & & 70 psig $=$ & 4.826321 & & & & & \\
\hline & $\mathrm{F} 1=4.5 \mathrm{~g}$ & $\mathrm{~m}=13.5 \mathrm{ft}$ & $/ \mathrm{s}=4.11 \mathrm{~m} / \mathrm{s}$ & & & & & & & & \\
\hline & $\mathrm{F} 1=5 \mathrm{gpn}$ & $=15.2 \mathrm{ft} / \mathrm{s}$ & $=4.63 \mathrm{~m} / \mathrm{s}$ & & & & & & & & \\
\hline
\end{tabular}




\section{Batch \#2 Data}

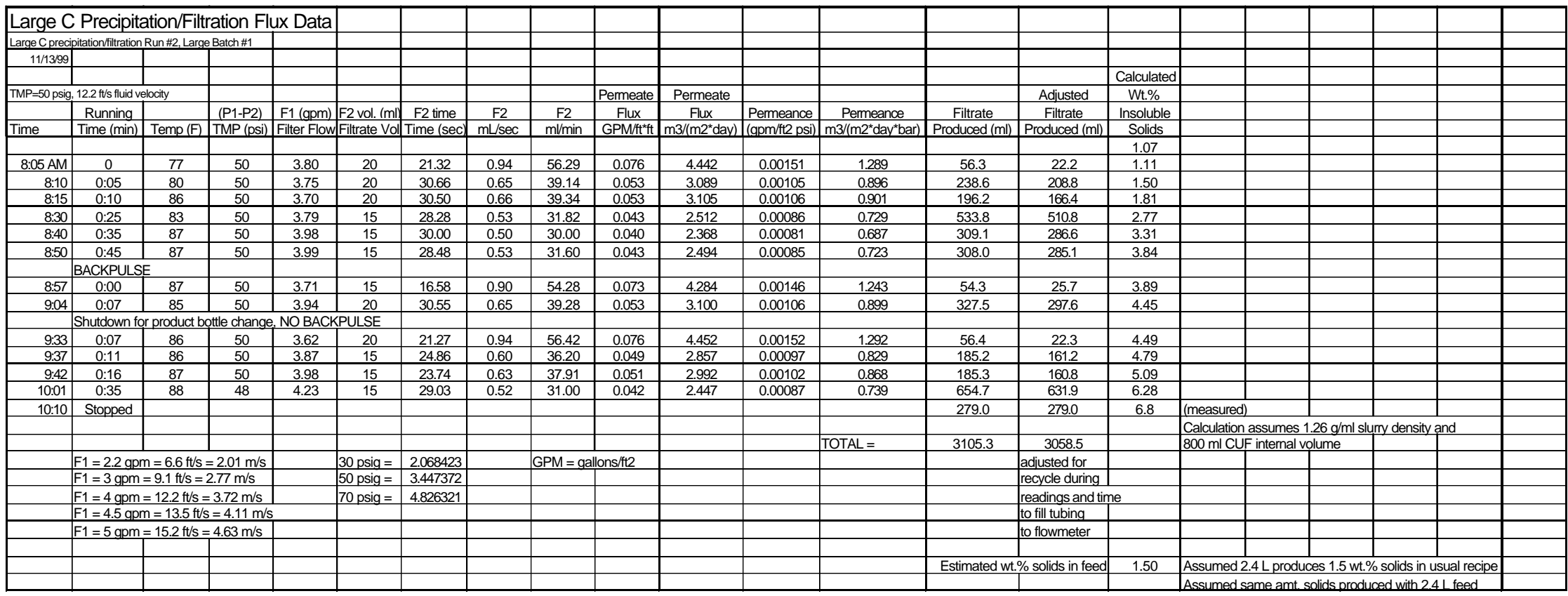




\section{Batch \#3 Data}

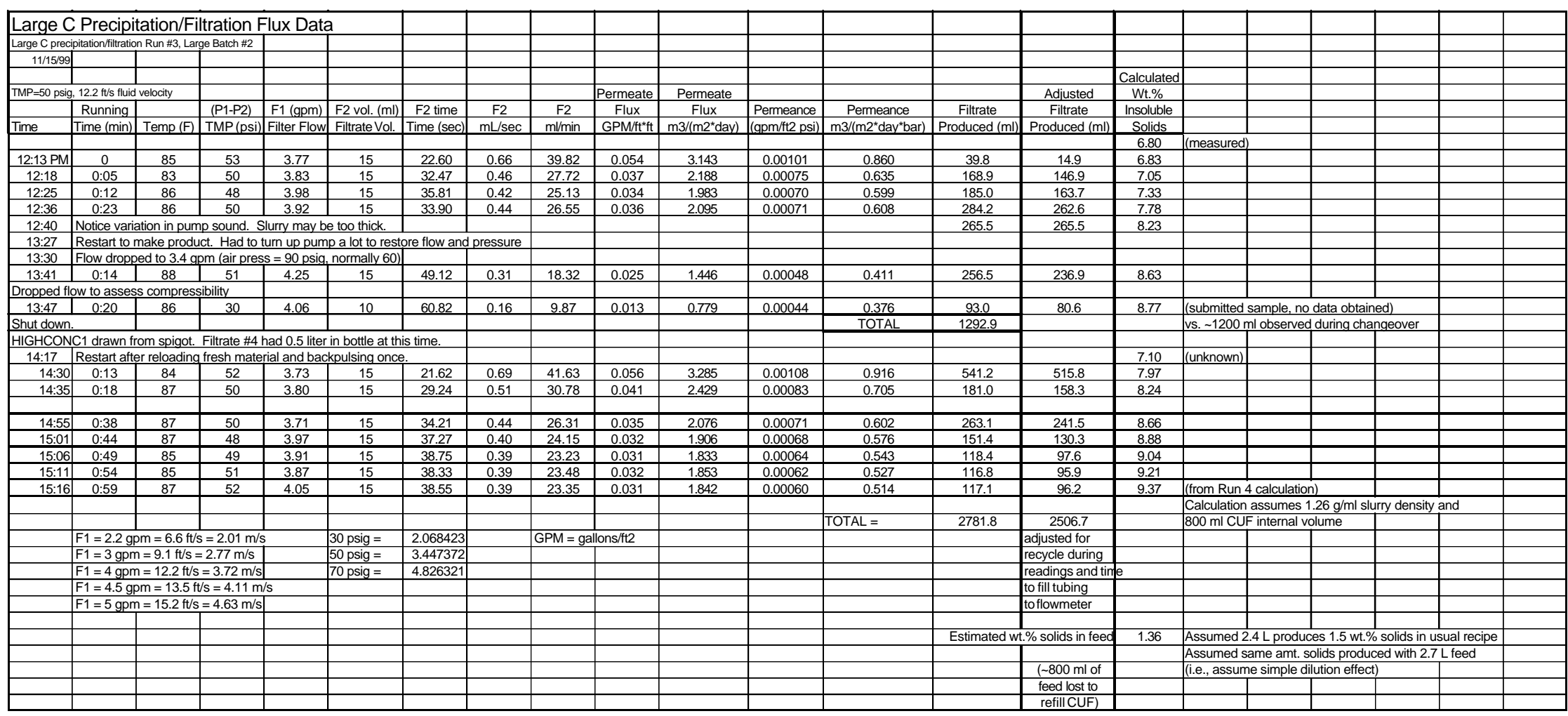


Batch \#4 Data

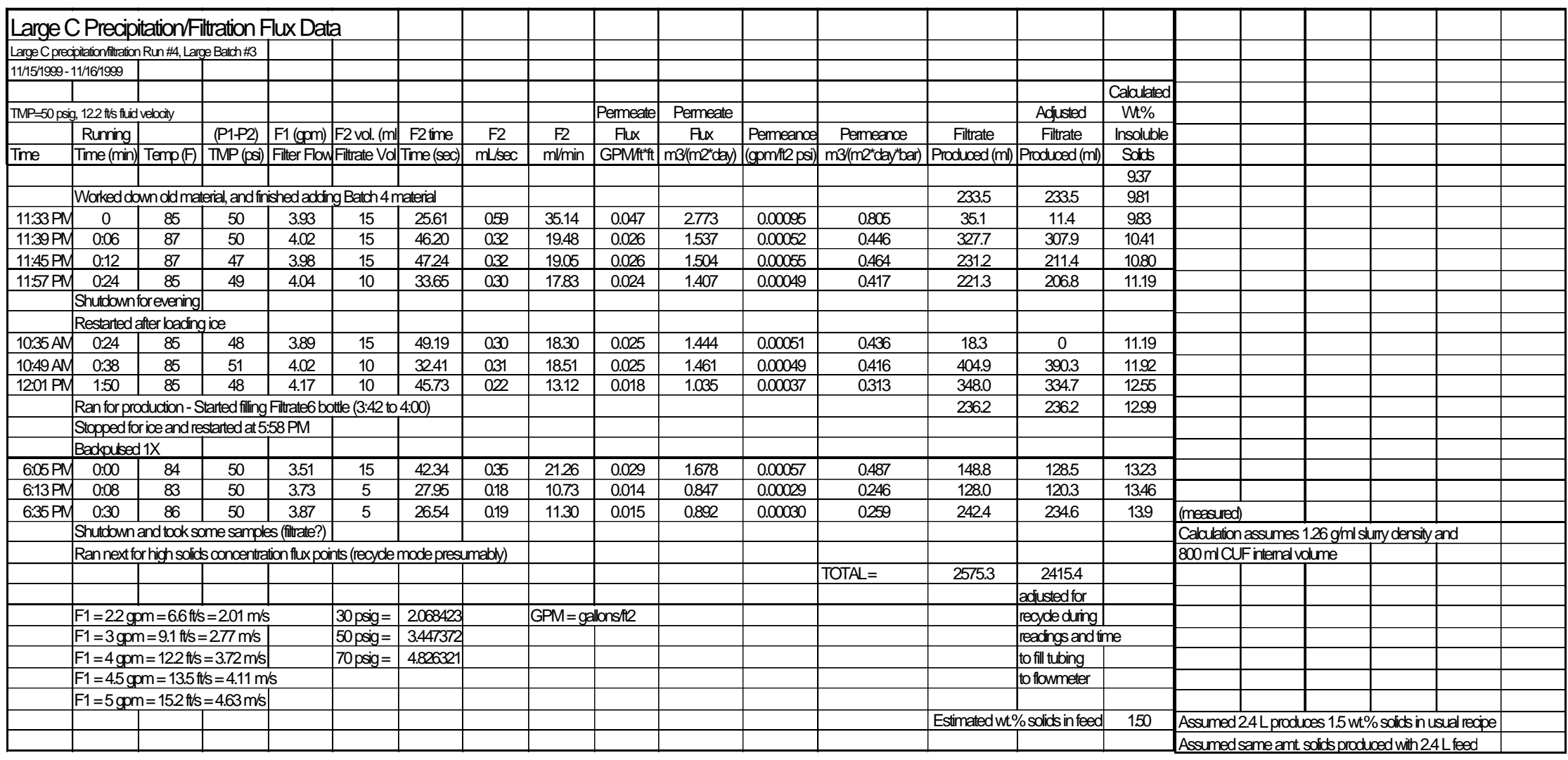




\section{High Insoluble Solids Concentration Run Data}

\begin{tabular}{|c|c|c|c|c|c|c|c|c|c|c|c|c|}
\hline \multicolumn{13}{|c|}{ Large C Precipitation/Filtration Flux Data } \\
\hline \multicolumn{13}{|c|}{ Large C precipitation/filtration Run \#4, Large Batch \#3 } \\
\hline \multicolumn{13}{|l|}{$11 / 16 / 99$} \\
\hline & & & & & & & & & & & & \\
\hline \multicolumn{13}{|c|}{ After filtering 2 of 3 liters of solution, filter fluxes dropped very low (concentrated solids about 8-10X). Did test matrix like in TTP. } \\
\hline & & & & & & & & & & & & \\
\hline \multicolumn{3}{|c|}{ TMP=70 psig, $12.2 \mathrm{ft} / \mathrm{s} \mathrm{fluid}$ velocity } & & & & & & & Permeate & Permeate & & \\
\hline & Running & & (P1-P2) & F1 (gpm) & F2 vol. $(\mathrm{ml})$ & F2 time & $\mathrm{F} 2$ & F2 & Flux & Flux & Permeance & Permeance \\
\hline Time & Time (HH:MM) & Temp (F) & TMP (psi) & Filter Flow & Filtrate Vol. & Time (sec) & $\mathrm{mL} / \mathrm{sec}$ & $\mathrm{ml} / \mathrm{min}$ & GPM/ft* ${ }^{* t t}$ & $\mathrm{~m} 3 /\left(\mathrm{m} 2^{*}\right.$ day $)$ & (gpm/ft2 psi) & $\mathrm{m3} /\left(\mathrm{m}^{*} \mathrm{day}^{*} \mathrm{bar}\right)$ \\
\hline $8: 35 \mathrm{PM}$ & 0 & 86 & 70 & 3.90 & 10 & 29.51 & 0.34 & 20.33 & 0.027 & 1.605 & 0.00039 & 0.332 \\
\hline $20: 40$ & $0: 05$ & 88 & 70 & 3.88 & 10 & 49.29 & 0.20 & 12.17 & 0.016 & 0.961 & 0.00023 & 0.199 \\
\hline $20: 45$ & $0: 10$ & 85 & 70 & 3.72 & 10 & 53.38 & 0.19 & 11.24 & 0.015 & 0.887 & 0.00022 & 0.184 \\
\hline $20: 50$ & $0: 15$ & 88 & 70 & 3.75 & 10 & 51.28 & 0.20 & 11.70 & 0.016 & 0.923 & 0.00022 & 0.191 \\
\hline $20: 55$ & $0: 20$ & 86 & 70 & 3.88 & 10 & 56.41 & 0.18 & 10.64 & 0.014 & 0.839 & 0.00020 & 0.174 \\
\hline $21: 00$ & $0: 25$ & 86 & 70 & 3.92 & 10 & 55.75 & 0.18 & 10.76 & 0.014 & 0.849 & 0.00021 & 0.176 \\
\hline \multirow[t]{3}{*}{$21: 05$} & $0: 30$ & 86 & 70 & 3.93 & 10 & 57.17 & 0.17 & 10.50 & 0.014 & 0.828 & 0.00020 & 0.172 \\
\hline & & & & & & & & & & & & \\
\hline & & & & & & & & & & & & \\
\hline \multicolumn{3}{|c|}{ TMP=30 psig, $15.1 \mathrm{ft} / \mathrm{s}$ fluid velocity } & & & & & & & Permeate & Permeate & & \\
\hline & Running & & (P1-P2) & F1 (gpm) & F2 vol. $(\mathrm{ml})$ & F2 time & $\mathrm{F} 2$ & $\mathrm{~F} 2$ & Flux & Flux & Permeance & Permeance \\
\hline Time & Time (HH:MM) & Temp (F) & TMP (psi) & Filter Flow & \begin{tabular}{|l|} 
Filtrate Vol. \\
\end{tabular} & Time (sec) & $\mathrm{mL} / \mathrm{sec}$ & $\mathrm{ml} / \mathrm{min}$ & GPM/ $/ \mathrm{ft}^{*} \mathrm{ft}$ & $\mathrm{m3} /\left(\mathrm{m} 2^{*}\right.$ day $)$ & (gpm/ft2 psi) & $\mathrm{m3} /\left(\mathrm{m}^{*} \mathrm{day}^{*} \mathrm{bar}\right)$ \\
\hline 9:17 PM & 0 & 83 & 30 & 5.10 & 10 & 32.50 & 0.31 & 18.46 & 0.025 & \begin{tabular}{|l|l|}
1.457 \\
\end{tabular} & 0.00083 & 0.704 \\
\hline $21: 22$ & $0: 05$ & 88 & 30 & 5.20 & 10 & 41.43 & 0.24 & 14.48 & 0.019 & 1.143 & 0.00065 & 0.553 \\
\hline $21: 27$ & $0: 10$ & 88 & 30 & 5.11 & 10 & 39.23 & 0.25 & 15.29 & 0.021 & 1.207 & 0.00069 & 0.584 \\
\hline $21: 32$ & $0: 15$ & 88 & 30 & 5.09 & 10 & 43.40 & 0.23 & 13.82 & 0.019 & 1.091 & 0.00062 & 0.527 \\
\hline $21: 37$ & $0: 20$ & 83 & 30 & 5.09 & 10 & 45.75 & 0.22 & 13.11 & 0.018 & 1.035 & 0.00059 & 0.500 \\
\hline $21: 42$ & $0: 25$ & 86 & 30 & 5.13 & 10 & 42.17 & 0.24 & 14.23 & 0.019 & 1.123 & 0.00064 & 0.543 \\
\hline \multirow[t]{2}{*}{$21: 47$} & $0: 30$ & 86 & 30 & 5.11 & 10 & 44.30 & 0.23 & 13.54 & 0.018 & 1.069 & 0.00061 & 0.517 \\
\hline & & & & & & & & & & & & \\
\hline \multirow{2}{*}{\multicolumn{3}{|c|}{ TMP=50 psig, $9.1 \mathrm{ft}$ s fluid velocity }} & & & & & & & Permeate & Permeate & & \\
\hline & & & (P1-P2) & F1 (gpm) & F2 vol. (ml) & F2 time & F2 & $\mathrm{F} 2$ & Flux & Flux & Permeance & Permeance \\
\hline Time & Time (HH:MM) & Temp (F) & TMP (psi) & Filter Flow & $\begin{array}{l}\text { Filtrate Vol. } \\
\end{array}$ & Time (sec) & $\mathrm{mL} / \mathrm{sec}$ & $\mathrm{ml} / \mathrm{min}$ & GPM/ft*ft & m3/(m2*day) & (gpm/ft2 psi) & $\mathrm{m3} /\left(\mathrm{m}^{*} \mathrm{day}^{*} \mathrm{bar}\right.$ \\
\hline $10: 42$ PM & $0: 00$ & 85 & 50 & 3.25 & 10 & 37.67 & 0.27 & 15.93 & 0.021 & 1.257 & 0.00043 & 0.365 \\
\hline $22: 47$ & $0: 05$ & 80 & 50 & 3.01 & 10 & 68.70 & 0.15 & 8.73 & 0.012 & 0.689 & 0.00023 & 0.200 \\
\hline $22: 52$ & $0: 10$ & 86 & 50 & 3.15 & 10 & 73.50 & 0.14 & 8.16 & 0.011 & 0.644 & 0.00022 & 0.187 \\
\hline $22: 57$ & $0: 15$ & 87 & 50 & 3.19 & 10 & 76.20 & 0.13 & 7.87 & 0.011 & 0.621 & 0.00021 & 0.180 \\
\hline $23: 02$ & $0: 20$ & 86 & 50 & 3.06 & 10 & 76.11 & 0.13 & 7.88 & 0.011 & 0.622 & 0.00021 & 0.180 \\
\hline $23: 07$ & $0: 25$ & 87 & 50 & 3.15 & 10 & 75.41 & 0.13 & 7.96 & 0.011 & 0.628 & 0.00021 & 0.182 \\
\hline \multirow[t]{7}{*}{$23: 12$} & $0: 30$ & 86 & 50 & 3.16 & 10 & 80.12 & 0.12 & 7.49 & 0.010 & 0.591 & 0.00020 & 0.171 \\
\hline & & & & & & & & & & & & \\
\hline & \multirow{2}{*}{\multicolumn{3}{|c|}{ Took rheology sample and HighConc: }} & 2 sample. & & \multirow{2}{*}{\multicolumn{5}{|c|}{$(15.7,13.3=14.5 \mathrm{wt} . \%$ avg. insoluble solids, measured) }} & & \\
\hline & \multirow{2}{*}{\multicolumn{4}{|c|}{\begin{tabular}{|l|} 
Drained rig to best possible. \\
Refilled CUF with remainder of Batch 4 \\
\end{tabular}}} & & & & & & & & \\
\hline & & & & & & & & & & & & \\
\hline & & & & & & & & & & & & \\
\hline & & & & & & & & & & & & \\
\hline & $\mathrm{F} 1=2.2 \mathrm{gpm}=$ & $6.6 \mathrm{ft} / \mathrm{s}=$ & $.01 \mathrm{~m} / \mathrm{s}$ & & $30 \mathrm{psig}=$ & \begin{tabular}{|l|}
2.068423 \\
\end{tabular} & & GPM $=$ gal & lons/ft2 & & & \\
\hline & $\mathrm{F} 1=3 \mathrm{gpm}=9$ & $1 \mathrm{ft} / \mathrm{s}=2$ & $7 \mathrm{~m} / \mathrm{s}$ & & $50 \mathrm{psig}=$ & \begin{tabular}{|l|}
3.447372 \\
\end{tabular} & & & & & & \\
\hline & $\mathrm{F} 1=4 \mathrm{gpm}=1$ & $2.2 \mathrm{ft} / \mathrm{s}=3$ & $72 \mathrm{~m} / \mathrm{s}$ & & $70 \mathrm{psig}=$ & \begin{tabular}{|l|}
4.826321 \\
\end{tabular} & & & & & & \\
\hline & $\mathrm{F} 1=4.5 \mathrm{gpm}=$ & $13.5 \mathrm{ft} / \mathrm{s}=$ & $4.11 \mathrm{~m} / \mathrm{s}$ & & & & & & & & & \\
\hline & $\mathrm{F} 1=$ & & & & & & & & & & & \\
\hline
\end{tabular}


Batch \#5 Data

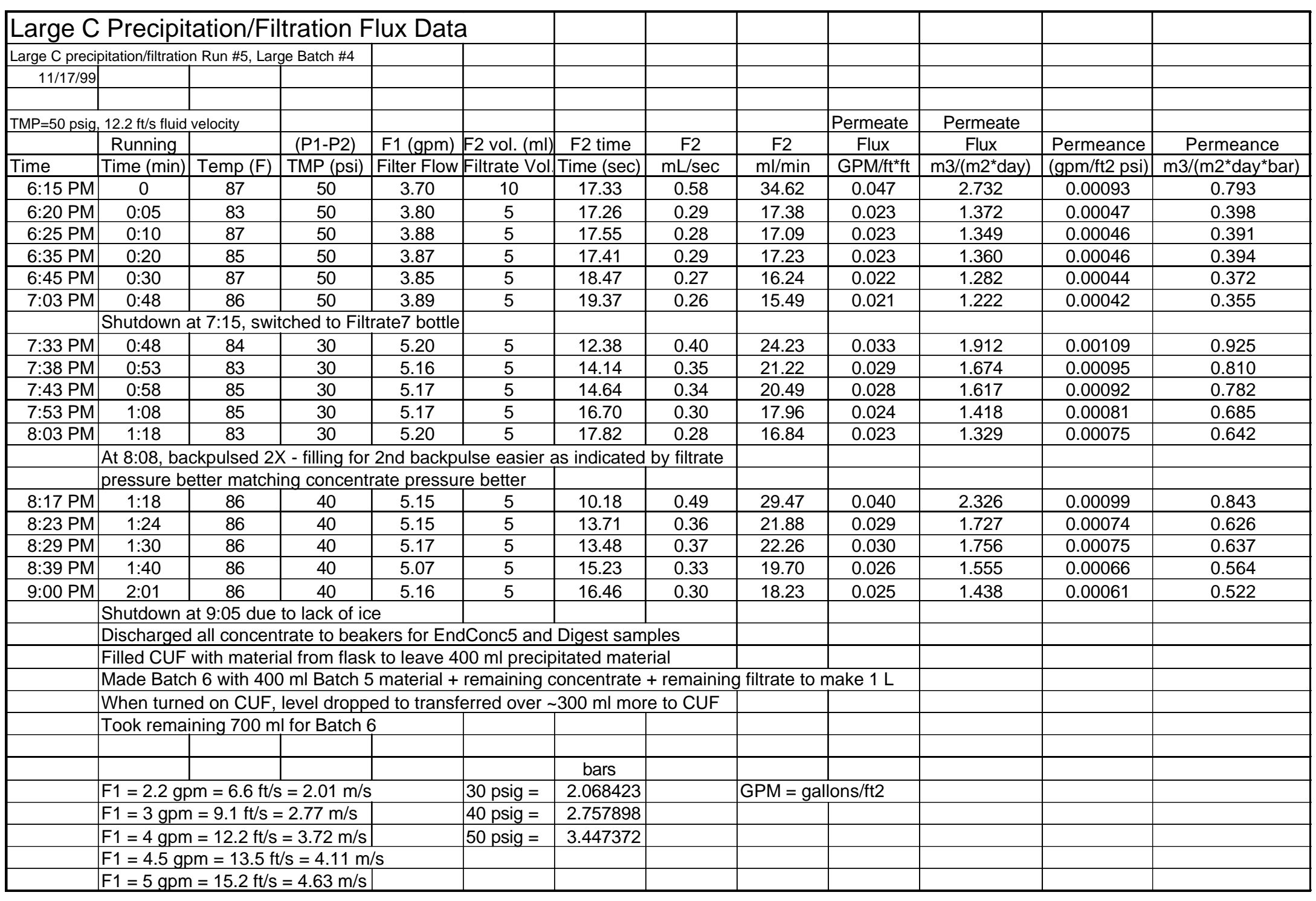




\section{Batch \#6 Data}

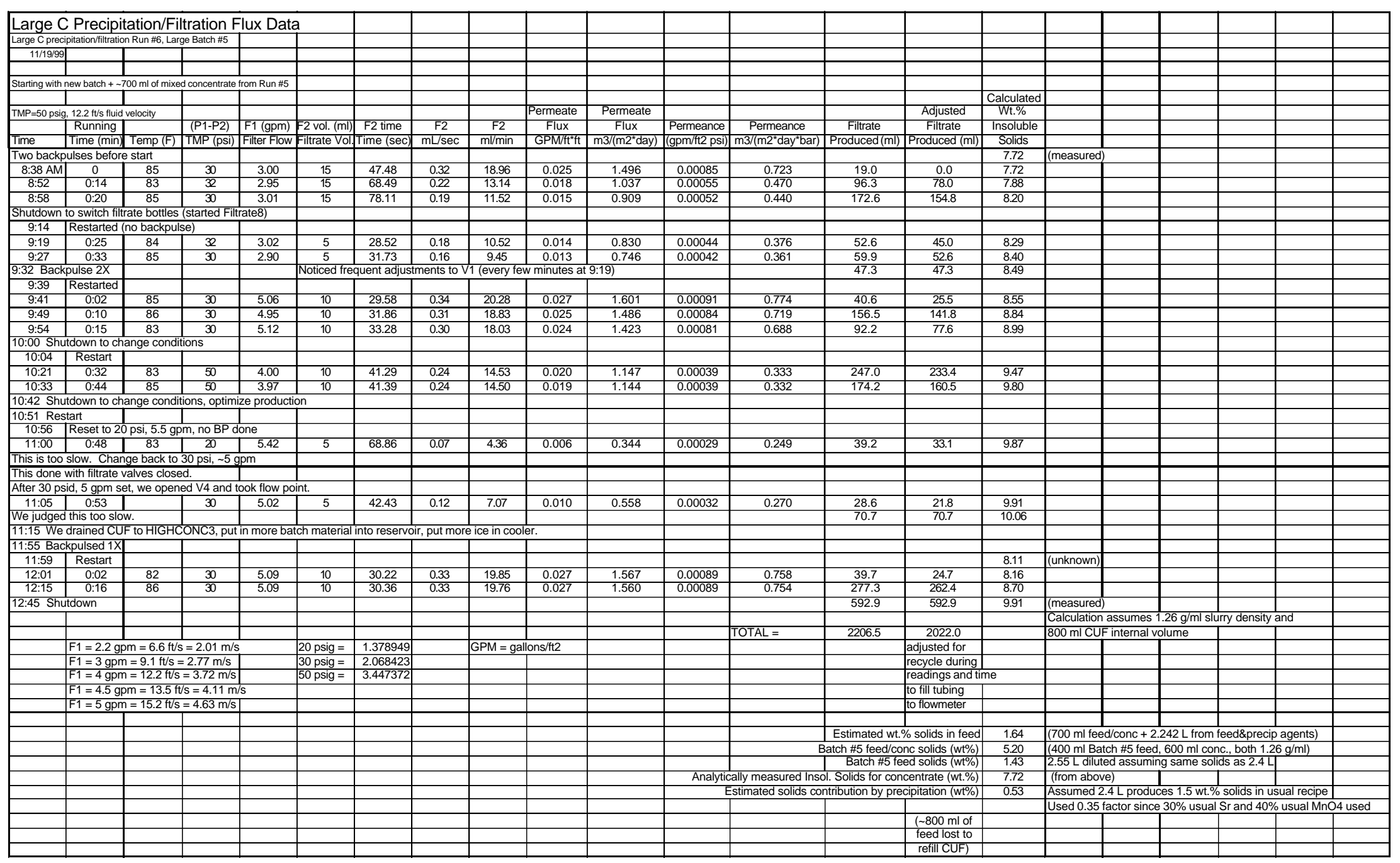




\section{Batch \#7 Data}

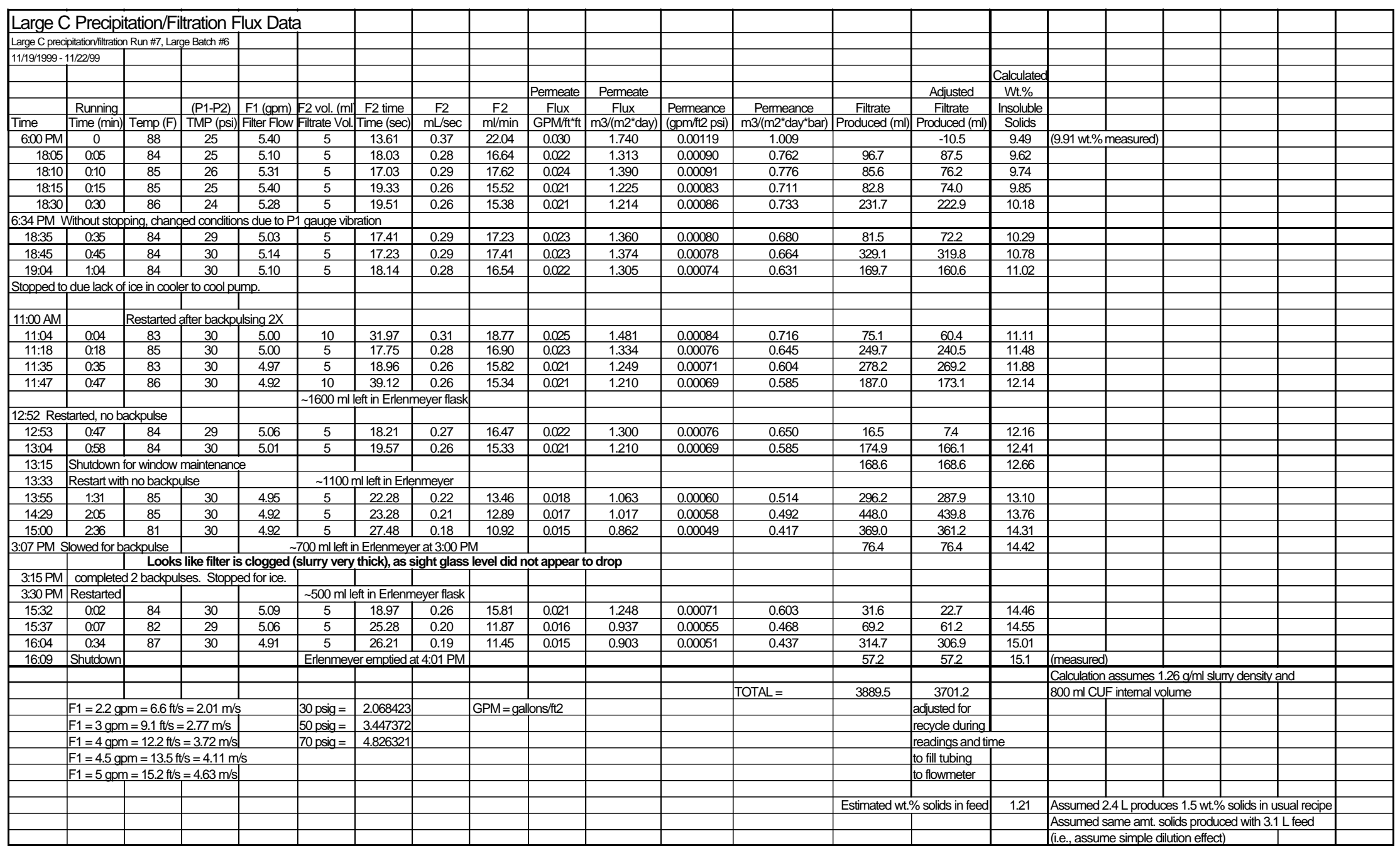




\section{Wash Run Data}

\begin{tabular}{|c|c|c|c|c|c|c|c|c|c|c|c|c|}
\hline \multicolumn{13}{|c|}{ Wash Run Filter Flux Data } \\
\hline \multicolumn{13}{|c|}{\begin{tabular}{|l|l|l|} 
Wash Runs 1-4 & & \\
\end{tabular}} \\
\hline \multicolumn{13}{|c|}{$11 / 29 / 1999-11 / 30 / 99$} \\
\hline & & & & & & & & & & & & \\
\hline \multirow[t]{2}{*}{ Run 1} & & & & & & & & & Permeate & Permeate & & \\
\hline & Running & & (P1-P2) & $\mathrm{F} 1$ (gpm) & F2 vol. (ml) & F2 time & F2 & $\mathrm{F} 2$ & Flux & Flux & Permeance & Permeance \\
\hline Time & Time (min) & Temp (F) & TMP (psi) & Filter Flow & Filtrate Vol. & Time (sec) & $\mathrm{mL} / \mathrm{sec}$ & $\mathrm{ml} / \mathrm{min}$ & GPM/ft*ft & m3/(m2*day) & $(\mathrm{gpm} / \mathrm{ft} 2 \mathrm{psi})$ & $\mathrm{m3} /\left(\mathrm{m} 2^{*} \mathrm{day}^{*} \mathrm{bar}\right)$ \\
\hline \multicolumn{13}{|c|}{\begin{tabular}{|l|l} 
Pumped in $~ 200 \mathrm{ml}$ of Wash solution, backpulsed $1 \mathrm{X}$ at $3: 43$ PM. & \\
\end{tabular}} \\
\hline 3:46 PM & 0 & 83 & 30 & 5 & 5 & 12.51 & 0.40 & 23.98 & 0.032 & 1.893 & 0.00108 & 0.915 \\
\hline $15: 51$ & $0: 05$ & 86 & 30 & 4.95 & 5 & 18.53 & 0.27 & 16.19 & 0.022 & 1.278 & 0.00073 & 0.618 \\
\hline $15: 56$ & $0: 10$ & 85 & 30 & 4.98 & 5 & 14.51 & 0.34 & 20.68 & 0.028 & 1.632 & 0.00093 & 0.789 \\
\hline $16: 01$ & $0: 15$ & 87 & 30 & 5.04 & 5 & 12.59 & 0.40 & 23.83 & 0.032 & 1.881 & 0.00107 & 0.909 \\
\hline $16: 06$ & $0: 20$ & 84 & 30 & 5.02 & 5 & 13.92 & 0.36 & 21.55 & 0.029 & 1.701 & 0.00097 & 0.822 \\
\hline $16: 11$ & $0: 25$ & 84 & 30 & 5.16 & 5 & 11.86 & 0.42 & 25.30 & 0.034 & 1.996 & 0.00113 & 0.965 \\
\hline \multicolumn{13}{|c|}{ 4:12 PM Stopped run as produced $600 \mathrm{ml}$ in WASH1 bottle, took samples. } \\
\hline & & & & & & & & & & & & \\
\hline & & & & & & & & & & & & \\
\hline \multirow[t]{2}{*}{ Run 2} & & & & & & & & & Permeate & Permeate & & \\
\hline & Running & & (P1-P2) & $\mathrm{F} 1$ (gpm) & F2 vol. (ml) & F2 time & $\mathrm{F} 2$ & $\mathrm{~F} 2$ & Flux & Flux & Permeance & Permeance \\
\hline Time & & $\operatorname{Temp}(\mathrm{F})$ & TMP (psi) & Filter Flow & Filtrate Vol. & Time $(\mathrm{sec})$ & $\mathrm{mL} / \mathrm{sec}$ & $\mathrm{ml} / \mathrm{min}$ & GPM/ft ${ }^{\star} \mathrm{ft}$ & $\mathrm{m} 3 /\left(\mathrm{m} 2^{*} \mathrm{day}\right)$ & $(\mathrm{gpm} / \mathrm{ft} 2 \mathrm{psi})$ & $\mathrm{m} 3 /\left(\mathrm{m} 2^{*} \mathrm{day}^{*} \mathrm{bar}\right)$ \\
\hline \multicolumn{13}{|c|}{\begin{tabular}{|l|l|l|l|l|}
$6: 23$ PM Backpulsed $1 \mathrm{X}$ & & & & \\
\end{tabular}} \\
\hline $6: 26 \mathrm{PM}$ & 0 & 86 & 30 & 4.93 & 5 & 9.39 & 0.53 & 31.95 & 0.043 & 2.521 & 0.00143 & 1.219 \\
\hline $18: 32$ & $0: 06$ & 86 & 30 & 5.06 & 5 & 8.71 & 0.57 & 34.44 & 0.046 & 2.718 & 0.00154 & 1.314 \\
\hline $18: 37$ & $0: 11$ & 83 & 30 & 5.00 & 5 & 7.95 & 0.63 & 37.74 & 0.051 & 2.978 & 0.00169 & 1.440 \\
\hline $18: 42$ & $0: 16$ & 84 & 30 & 5.01 & 5 & 8.42 & 0.59 & 35.63 & 0.048 & 2.812 & 0.00160 & 1.359 \\
\hline $18: 47$ & $0: 21$ & 84 & 30 & 4.96 & 5 & 8.01 & 0.62 & 37.45 & 0.050 & 2.956 & 0.00168 & 1.429 \\
\hline \multicolumn{13}{|c|}{ 6:48 PM Shutdown. Made $600 \mathrm{ml}$ filtrate. Sampled system next morning. } \\
\hline & & & & & & & & & & & & \\
\hline & & & & & & & & & & & & \\
\hline \multirow[t]{2}{*}{ Run 3} & & & & & & & & & Permeate & Permeate & & \\
\hline & Running & & $(\mathrm{P} 1-\mathrm{P} 2)$ & $\mathrm{F} 1$ (gpm) & F2 vol. (ml) & F2 time & F2 & F2 & Flux & Flux & Permeance & Permeance \\
\hline Time & Time (min) & Temp (F) & TMP (psi) & Filter Flow & Filtrate Vol. & Time (sec) & $\mathrm{mL} / \mathrm{sec}$ & $\mathrm{ml} / \mathrm{min}$ & GPM/ft*ft & $\mathrm{m} 3 /\left(\mathrm{m} 2^{*} \mathrm{day}\right)$ & $(\mathrm{gpm} / \mathrm{ft} 2 \mathrm{psi})$ & $\mathrm{m3} /\left(\mathrm{m}^{*} \mathrm{day}^{*} \mathrm{bar}\right)$ \\
\hline \multicolumn{13}{|c|}{\begin{tabular}{|l|l|l|l|l|} 
12:54 PM Backpulsed 1X & & & & \\
\end{tabular}} \\
\hline 12:57 PM & & & $\mathrm{ad}$ & $n$ as pe & ic was & orking. & Tried to cle & n sight gl & Ss of reser & voir to no avail. & & \\
\hline PUMP VE & RY HARD T & O RESTAR & & & & & & & & & & \\
\hline 1:31 PM F & Reestablishe & d flow cond & jitions & & & & & & & & & \\
\hline $1: 33 \mathrm{PM}$ & 0 & 88 & 30 & 4.95 & 5 & 5.53 & 0.90 & 54.25 & 0.073 & 4.281 & 0.00243 & 2.070 \\
\hline $13: 38$ & $0: 05$ & 85 & 28 & 5.15 & 5 & 7.71 & 0.65 & 38.91 & 0.052 & 3.071 & 0.00187 & 1.591 \\
\hline $13: 43$ & $0: 10$ & 83 & 30 & 5.01 & 5 & 6.85 & 0.73 & 43.80 & 0.059 & 3.456 & 0.00196 & 1.671 \\
\hline $13: 48$ & $0: 15$ & 86 & 29 & 4.72 & 5 & 8.31 & 0.60 & 36.10 & 0.049 & 2.849 & 0.00167 & 1.425 \\
\hline 1:52 PM S & Shutdown. F & inished mak & king $600 \mathrm{ml}$ & filtrate & & & & & & & & \\
\hline & & & & & & & & & & & & \\
\hline & & & & & & & & & & & & \\
\hline Run 4 & & & & & & & & & Permeate & Permeate & & \\
\hline & Running & & (P1-P2) & $\mathrm{F} 1$ (gpm) & F2 vol. (ml & F2 time & $\mathrm{F} 2$ & $\mathrm{~F} 2$ & Flux & Flux & \begin{tabular}{|l|} 
Permeance \\
\end{tabular} & Permeance \\
\hline Time & Time (min) & Temp (F) & TMP (psi) & Filter Flow & Filtrate Vol. & Time (sec) & $\mathrm{mL} / \mathrm{sec}$ & $\mathrm{ml} / \mathrm{min}$ & GPM/ft*ft & $\mathrm{m} 3 /\left(\mathrm{m} 2^{*} \mathrm{dav}\right)$ & $(\mathrm{gpm} / \mathrm{ft} 2 \mathrm{psi})$ & $\mathrm{m3} /\left(\mathrm{m}^{*}{ }^{*} \mathrm{day}^{*} \mathrm{bar}\right)$ \\
\hline $4: 17 \mathrm{PM}$ & Backpulsed & $2 \mathrm{X}$ (pump s & topped mov & ing during $\mathrm{f}$ & first backpul & & & & & & & \\
\hline $4: 21 \mathrm{PM}$ & Established & w condit & S. Tried & $\mathrm{P}=50 \mathrm{P}$ & $12.2 \mathrm{ft} / \mathrm{s} \mathrm{b}$ & ut pump lab & ored hard. & Set as belc & & & & \\
\hline 4:24 PM & 0 & 81 & 41 & 3.83 & 5 & 9.54 & 0.52 & 31.45 & 0.042 & 2.482 & 0.00103 & 0.878 \\
\hline $16: 28$ & $0: 04$ & 84 & 39 & 4.16 & 5 & 10.05 & 0.50 & 29.85 & 0.040 & 2.356 & 0.00103 & 0.876 \\
\hline $16: 34$ & $0: 10$ & 86 & 39 & 4.19 & 5 & 10.12 & 0.49 & 29.64 & 0.040 & 2.340 & 0.00102 & 0.870 \\
\hline $16: 39$ & $0: 15$ & 86 & 39 & 4.10 & 5 & 9.94 & 0.50 & 30.18 & 0.041 & 2.382 & 0.00104 & 0.886 \\
\hline $16: 44$ & $0: 20$ & 85 & 38 & 4.00 & 5 & 11.35 & 0.44 & 26.43 & 0.036 & 2.086 & 0.00094 & 0.796 \\
\hline $16: 50$ & $0: 26$ & 82 & 39 & 4.09 & 5 & 9.85 & 0.51 & 30.46 & 0.041 & 2.404 & 0.00105 & 0.894 \\
\hline $4: 52$ PM & Made $600 \mathrm{~m}$ & wash filtra & te and stopp & ped run. & & & & & & & & \\
\hline UF pump & $\mathrm{did}$ not st & when trie & to empty & oncentra & m CUF & d up to & $-90 \mathrm{psi}$ & essur & & & & \\
\hline & & & & & & & & & & & & \\
\hline & & & & & & & & & & & & \\
\hline & $\mathrm{F} 1=2.2 \mathrm{gr}$ & $\mathrm{pm}=6.6 \mathrm{ft} / \mathrm{s}$ & $s=2.01 \mathrm{~m} / \mathrm{s}$ & & 30 psig $=$ & 2.068423 & & GPM = gal & ons/ft2 & & & \\
\hline & $\mathrm{F} 1=3 \mathrm{gpm}$ & $=9.1 \mathrm{ft} / \mathrm{s}=$ & $=2.77 \mathrm{~m} / \mathrm{s}$ & & $40 \mathrm{psig}=$ & 2.757898 & & & & & & \\
\hline & $\mathrm{F} 1=4 \mathrm{gpm}$ & $=12.2 \mathrm{ft} / \mathrm{s}$ & $=3.72 \mathrm{~m} / \mathrm{s}$ & & 50 psig $=$ & 3.447372 & & & & & & \\
\hline & $\mathrm{F} 1=4.5 \mathrm{gp}$ & $\mathrm{om}=13.5 \mathrm{ft}$ & $\mathrm{s}=4.11 \mathrm{~m} / \mathrm{s}$ & & & & & & & & & \\
\hline & $\mathrm{F} 1=5 \mathrm{gpm}$ & $\mathrm{n}=15.2 \mathrm{ft} / \mathrm{s}$ & $=4.63 \mathrm{~m} / \mathrm{s}$ & & & & & & & & & \\
\hline
\end{tabular}




\section{Post Filtration Clean Water Flux Data}

\begin{tabular}{|c|c|c|c|c|c|c|c|c|c|c|c|c|}
\hline \multicolumn{13}{|c|}{ Post-Run Clean Water Flux Data } \\
\hline \multicolumn{13}{|c|}{ Post-run Clean Water Runs 1-4 } \\
\hline \multicolumn{13}{|c|}{ 12/13/1999 - 12/16/1999 } \\
\hline & & & & & & & & & & & & \\
\hline \multirow[t]{2}{*}{ Run 1} & & & & & & & & & Permeate & Permeate & & \\
\hline & Running & & (P1-P2) & F1 (gpm) & F2 vol. (ml) & F2 time & $\mathrm{F} 2$ & $\mathrm{~F} 2$ & Flux & Flux & Permeance & Permeance \\
\hline \multirow[t]{2}{*}{ Time } & Time (min) & Temp (F) & TMP (psi) & Filter Flow & Filtrate Vol. & Time (sec) & $\mathrm{mL} / \mathrm{sec}$ & $\mathrm{ml} / \mathrm{min}$ & GPM/ft*ft & $\mathrm{m} 3 /\left(\mathrm{m}^{*} \mathrm{day}\right)$ & (gpm/ft2 psi) & $\mathrm{m3} /\left(\mathrm{m} 2^{*} \mathrm{day}^{*} \mathrm{bar}\right)$ \\
\hline & \multicolumn{3}{|c|}{ Backpulsed $1 \mathrm{X}$ before run (12/15) } & & & & & & & & & \\
\hline 10:07 AM & $0: 00$ & 77 & 15 & 4.26 & 20 & 4.71 & 4.25 & 254.78 & 0.343 & 20.107 & 0.02285 & 19.442 \\
\hline $10: 12$ AM & $0: 05$ & 81 & 15 & 4.10 & 20 & 10.00 & 2.00 & 120.00 & 0.161 & 9.470 & 0.01076 & 9.157 \\
\hline 10:17 AM & $0: 10$ & 85 & 15 & 4.12 & 20 & 10.75 & 1.86 & 111.63 & 0.150 & 8.810 & 0.01001 & 8.518 \\
\hline 10:22 AM & $0: 15$ & 85 & 15 & 4.15 & 20 & 11.34 & 1.76 & 105.82 & 0.142 & 8.351 & 0.00949 & 8.075 \\
\hline \multirow[t]{2}{*}{ 10:27 AM } & $0: 20$ & 88 & 15 & 4.14 & 20 & 14.28 & 1.40 & 84.03 & 0.113 & 6.632 & 0.00754 & 6.413 \\
\hline & & & & & & & & & & & & \\
\hline \multirow[t]{2}{*}{ Run 2} & & & & & & & & & Permeate & Permeate & & \\
\hline & Running & & (P1-P2) & $\mathrm{F} 1$ (gpm) & F2 vol. (ml) & F2 time & F2 & F2 & Flux & Flux & Permeance & Permeance \\
\hline \multirow[t]{2}{*}{ Time } & Time (min) & Temp (F) & TMP (psi) & Filter Flow & Filtrate Vol. & Time (sec) & $\mathrm{mL} / \mathrm{sec}$ & $\mathrm{ml} / \mathrm{min}$ & GPM/ft*ft & $\mathrm{m} 3 /\left(\mathrm{m}^{*}\right.$ day $)$ & (apm/ft2 psi) & $\mathrm{m} 3 /\left(\mathrm{m} 2^{*} \mathrm{day}^{*}\right.$ bar $)$ \\
\hline & \multicolumn{3}{|c|}{ Backpulsed $2 X$ before run $(12 / 16)$} & & & & & & & & & \\
\hline 2:40 PM & 0:00 & 78 & 10 & 4.10 & 20 & 8.71 & 2.30 & 137.77 & 0.185 & 10.873 & 0.01853 & 15.770 \\
\hline 2:45 PM & $0: 05$ & 82 & 10 & 4.11 & 20 & 14.18 & 1.41 & 84.63 & 0.114 & 6.679 & 0.01138 & 9.687 \\
\hline $2: 50$ PM & $0: 10$ & 86 & 10 & 4.13 & 20 & 14.53 & 1.38 & 82.59 & 0.111 & 6.518 & 0.01111 & 9.453 \\
\hline $2: 56 \mathrm{PM}$ & $0: 16$ & 84 & 10 & 4.13 & 20 & 15.53 & 1.29 & 77.27 & 0.104 & 6.098 & 0.01039 & 8.845 \\
\hline 3:01 PM & $0: 21$ & 83 & 10 & 4.11 & 20 & 16.40 & 1.22 & 73.17 & 0.098 & 5.775 & 0.00984 & 8.375 \\
\hline \multirow[t]{2}{*}{ 3:06 PM } & $0: 26$ & 84 & 10 & 4.12 & 20 & 15.96 & 1.25 & 75.19 & 0.101 & 5.934 & 0.01011 & 8.606 \\
\hline & & & & & & & & & & & & \\
\hline & & & & & & & & & & & & \\
\hline \multirow{2}{*}{ Run 3} & & & & & & & & & Permeate & Permeate & & \\
\hline & Running & & (P1-P2) & F1 (gpm) & F2 vol. (ml) & F2 time & F2 & F2 & Flux & Flux & Permeance & Permeance \\
\hline Time & Time (min) & $\operatorname{Temp}(\mathrm{F})$ & TMP (psi) & Filter Flow & Filtrate Vol. & Time (sec) & $\mathrm{mL} / \mathrm{sec}$ & $\mathrm{ml} / \mathrm{min}$ & GPM/ftt & $\mathrm{m3} /\left(\mathrm{m} 2^{*}\right.$ day $)$ & (gpm/ft2 psi) & $\mathrm{m} 3 /\left(\mathrm{m} 2^{*}\right.$ day $^{*}$ bar $)$ \\
\hline 3:17 PM & $0: 00$ & 84 & 20 & 4.11 & 20 & 5.21 & 3.84 & 230.33 & 0.310 & 18.177 & 0.01549 & 13.182 \\
\hline 3:22 PM & 0:05 & 82 & 20 & 4.04 & 20 & 7.21 & 2.77 & 166.44 & 0.224 & 13.135 & 0.01119 & 9.525 \\
\hline $3: 28$ PM & $0: 11$ & 84 & 20 & 4.06 & 20 & 7.68 & 2.60 & 156.25 & 0.210 & 12.331 & 0.01051 & 8.943 \\
\hline 3:32 PM & $0: 15$ & 84 & 20 & 4.01 & 20 & 7.93 & 2.52 & 151.32 & 0.204 & 11.943 & 0.01018 & 8.661 \\
\hline 3:38 PM & $0: 21$ & 79 & 20 & 3.99 & 20 & 8.40 & 2.38 & 142.86 & 0.192 & 11.274 & 0.00961 & 8.176 \\
\hline \multirow[t]{7}{*}{ 3:42 PM } & $0: 25$ & 83 & 20 & 4.01 & 20 & 8.03 & 2.49 & 149.44 & 0.201 & 11.794 & 0.01005 & 8.553 \\
\hline & & & & & & & & & & & & \\
\hline & \multicolumn{4}{|c|}{$\mathrm{F} 1=2.2 \mathrm{gpm}=6.6 \mathrm{ft} / \mathrm{s}=2.01 \mathrm{~m} / \mathrm{s}$} & 20 psig $=$ & 1.378949 & & \multicolumn{2}{|c|}{ GPM = gallons/ft2 } & & & \\
\hline & \multicolumn{3}{|c|}{$\mathrm{F} 1=3 \mathrm{gpm}=9.1 \mathrm{ft} / \mathrm{s}=2.77 \mathrm{~m} / \mathrm{s}$} & & 15 psig $=$ & 1.034212 & & & & & & \\
\hline & \multicolumn{3}{|c|}{$\mathrm{F} 1=4 \mathrm{gpm}=12.2 \mathrm{ft} / \mathrm{s}=3.72 \mathrm{~m} / \mathrm{s}$} & & 10 psig $=$ & 0.689474 & & & & & & \\
\hline & \multirow{2}{*}{\multicolumn{3}{|c|}{\begin{tabular}{|l}
$F 1=4.5 \mathrm{gpm}=13.5 \mathrm{ft} / \mathrm{s}=4.11 \mathrm{~m} / \mathrm{s}$ \\
$F 1=5 \mathrm{gpm}=15.2 \mathrm{ft} / \mathrm{s}=4.63 \mathrm{~m} / \mathrm{s}$
\end{tabular}}} & & & & & & & & & \\
\hline & & & & & & & & & & & & \\
\hline
\end{tabular}

